\title{
Amino Acid Salt Solutions for Carbon Dioxide Capture
}

Magdalena Elżbieta Majchrowicz 
Amino Acid SAlt SOlUTIONS FOR

Carbon Dioxide Capture 


\section{Graduation committee:}

Chairman:

Promoters:

Assistant promoter:

Members:
Prof. dr. ir. J.W.M. Hilgenkamp

Prof. dr. S.R.A. Kersten

Prof. dr. ir. W.P.M. van Swaaij

Dr. ir. D.W.F. Brilman

Prof. dr. ir. D.C. Nijmeijer

Prof. dr. ir. N.E. Benes

Prof. dr. ir. H.J. Heeres

Prof. dr. Ir. W. Prins
University of Twente

University of Twente

University of Twente

University of Twente

Universtiy of Twente

Universtiy of Twente

RUG

Ghent University

This research was carried out within the CATO program. It was financially supported by the Dutch Ministry of Economic Affairs (EZ) and the consortium partners. The author gratefully acknowledges the financial support.

Cover: Białowieża Forest (Poland) - the last remains of the primeval forest which once covered most of Europe at the end of the last ice age. Among others, the forest is home to the world's largest population of European bison, the continent's heaviest land animals. Bełchatów Power Station (Poland) - Europe's largest coal-fired power plant and biggest single $\mathrm{CO}_{2}$ emitter. To reduce $\mathrm{CO}_{2}$ emissions, the company has been taking actions to introduce the carbon capture and storage (CCS) process.

\section{AMINO ACID SALt SOLUTIONS FOR CARBON DiOXIDE CAPTURE}

Magdalena Elżbieta Majchrowicz

ISBN: $978-90-365-3780-3$

DOI: $10.3990 / 1.9789036537803$

URL: http://dx.doi.org/10.3990/1.9789036537803

No part of this work may be reproduced by print, photography, or any other means without the written permission from the author.

Copyright $@$ by Magdalena Elżbieta Majchrowicz, Enschede, The Netherlands, 2014. 


\title{
Amino Acid SAlt SOlUTIONS FOR CARBON Dioxide CAPTURE
}

\author{
DISSERTATION
}

to obtain

the degree of doctor at the University of Twente,

on the authority of the rector magnificus,

prof. dr. H. Brinksma,

on account of the decision of the graduation committee, to be publicly defended

on Friday $7^{\text {th }}$ of November 2014 at 14.45

by

Magdalena Elżbieta Majchrowicz

born in Czeladź, Poland 
This dissertation has been approved by:

Prof. dr. S.R.A. Kersten

Prof. dr. ir. W.P.M. van Swaaij

Dr. ir. D.W.F. Brilman 
To my beloved husband and son 



\section{Summary}

Reactive absorption is a common process in the chemical industry and is used, among others, in the treatment of $\mathrm{CO}_{2}$ containing industrial gas streams. For removal of $\mathrm{CO}_{2}$ from industrial gases by chemical absorption, aqueous solutions of (alkanol)amines such as MEA, DGA, DEA, DIPA and MDEA (or their mixtures with or without "activators" such as piperazine) are commonly used. In principle, these systems could be used for the removal of the greenhouse gas $\mathrm{CO}_{2}$ from flue gases, such as from power plants. However, these solvents have several drawbacks, related to a limited cyclic $\mathrm{CO}_{2}$ loading capacity, resulting in high energy costs for regeneration, they contribute (without counter measures) to a relatively high equipment corrosion rate and suffer from degradation in an oxygen rich atmosphere, resulting in toxic degradation products.

Aqueous alkaline salts of amino acids may provide a promising alternative for these aqueous (alkanol)amine solutions. Generally, amino acid salt solutions can be characterized by a higher stability towards oxidative degradation, a good level of biodegradability combined with low toxicity, viscosities and surface tensions similar to water; which is important in case of membrane gas absorption. They have also the ability to precipitate a solid product when absorbing $\mathrm{CO}_{2}$; especially for solutions at high amino acid salt concentration and at high liquid $\mathrm{CO}_{2}$ loading. Although amino acids (salts) have been applied in a number of industrial applications, information on these systems was still rather limited. The current work was a part of a project with the aim to assess new reactive solvents based of amino acid salts for $\mathrm{CO}_{2}$ removal from industrial gas streams.

With the use of a smart screening method, the precipitation regime (or the "window of operation") for a series of amino acid salts (taurine, sarcosine, L-proline, $\beta$-alanine, 6 -aminohexanoic acid and DL-methionine) was determined under varying conditions for the $\mathrm{CO}_{2}$ absorption process (varying temperature, $\mathrm{CO}_{2}$ partial pressure and solvent concentration). Except for DL-methionine, a relatively broad window of operation without precipitation could be observed for all the amino acid salt solutions studied. The transition zone from non-precipitating to precipitating system has been identified and was found to be a strong function of the process operational conditions. At constant temperature, the boundary of precipitation shifts to lower $\mathrm{CO}_{2}$ partial pressure with increasing amino acid salt concentration. Alternatively, at constant $\mathrm{CO}_{2}$ partial pressure, this boundary shifts to 
higher solvent concentration with increasing temperature, due to both the influence of absorption temperature and chemical speciation in the liquid phase on the solubility products of the precipitates. The identity of the precipitates formed was investigated and revealed. Their visual appearance was also characterized, which may be very important, e.g., from a slurry handling point of view. Some slurries were easily re-suspended, whereas others formed gels or networks, which are likely to clog process equipment. It was found that alkaline salts of taurine and DL-methionine precipitate upon saturating the solution with $\mathrm{CO}_{2}$ - the zwitterion (an amino acid itself), whereas L-proline, $\beta$-alanine, sarcosine and 6-aminohexanoic acid form $\mathrm{CO}_{2}$ containing solids. In latter case, high aqueous solubility of the zwitterion in combination with high base strength of the solutions create favourable conditions for precipitating a bicarbonate salt; for which no earlier reports in literature could be found. Equilibrium $\mathrm{CO}_{2}$ absorption-desorption experiments have been carried out for $1 \mathrm{~mol} \cdot \mathrm{dm}^{-3}$ aqueous amino acid salt solutions. Under these screening conditions, the amino acid salts tested had comparable cyclic capacities (derived as the difference between $\mathrm{CO}_{2}$ solubilities at 313 and $373 \mathrm{~K}$ ) to the industry standard MEA, but only L-proline and sarcosine also showed (according to literature) higher reactivity towards $\mathrm{CO}_{2}$. Based on the results of this study, the (alkaline salt of) imino acid L-proline was chosen for further investigation in this thesis. For this solvent, important characteristics such as physicochemical properties, $\mathrm{CO}_{2}$ absorption kinetics, thermodynamic equilibria and energy consumption for the regeneration were determined.

A study towards the kinetics of $\mathrm{CO}_{2}$ in aqueous potassium L-prolinate solutions was performed in a stirred reactor with a flat gas-liquid interface, for the solution concentration range of $0.5-3 \mathrm{~mol} \cdot \mathrm{dm}^{-3}$ and over the temperature range of 290-303 $\mathrm{K}$. To compare the effect of potassium versus sodium as a counterion, the absorption rate of $\mathrm{CO}_{2}$ in aqueous solutions of sodium salt of L-proline was also measured at $298 \mathrm{~K}$, for the same range of solution concentrations. The obtained experimental reactive absorption fluxes were interpreted, using the pseudo-first order approach, into intrinsic reaction kinetics. The reaction order with respect to the amino acid, assuming power-law kinetics, was found to be between 1.40 and 1.44 for both considered salts; indicating significant contributions from both L-prolinate and water to the zwitterion deprotonation. In terms of kinetics, potassium salt of L-proline shows, on average, a $32 \%$ higher reactivity towards $\mathrm{CO}_{2}$ than the sodium equivalent; and reacts faster with $\mathrm{CO}_{2}$ than most (alkanol)amines and amino acid salts. The second order kinetic rate constant, $k_{2}$, is found to be $93 \cdot 7 \cdot 10^{3} \mathrm{dm}^{3} \cdot \mathrm{mol}^{-1} \cdot \mathrm{s}^{-1}$ at $298 \mathrm{~K}$, with an activation energy of $43.3 \mathrm{~kJ} \cdot \mathrm{mol}^{-1}$. Potassium L-prolinate may be therefore attractive in the bulk $\mathrm{CO}_{2}$ capture, either as a solvent or as a kinetic promoter to other high capacity, low energy $\mathrm{CO}_{2}$ capture solutions. 
Complementary to the absorption rate data, the density and dynamic viscosity of potassium, sodium and lithium salts of L-proline were determined over the temperature range of 284-313 K, for solution concentrations from $0.1 \mathrm{~mol} \cdot \mathrm{dm}^{-3}$ to the maximum concentration (as determined during the amino acid salts screening activities, described in Chapter 2 of this thesis). To estimate the $\mathrm{CO}_{2}$ solubility in amino acid salt solutions, essential for deriving reaction kinetic data, the analogy with the non-reactive $\mathrm{N}_{2} \mathrm{O}$ was used and therefore the solubility of $\mathrm{N}_{2} \mathrm{O}$ in aqueous L-prolinate solutions (potassium and sodium salts) was measured. For the range of conditions tested, temperatures from 284 to $313 \mathrm{~K}$ and solution concentrations of 0.1 to $3 \mathrm{~mol} \cdot \mathrm{dm}^{-3}$, a typical "salting out" behaviour was found.

The absorption capacity ("solubility") of $\mathrm{CO}_{2}$ in aqueous solutions of potassium L-prolinate was measured for temperatures from 285 to $323 \mathrm{~K}$, for the solution concentration range of $0.5-3 \mathrm{~mol} \cdot \mathrm{dm}^{-3}$ and $\mathrm{CO}_{2}$ partial pressures relevant to flue gas conditions and up to $70 \mathrm{kPa}$. The effect of absorbent concentration, temperature and $\mathrm{CO}_{2}$ partial pressure on the overall $\mathrm{CO}_{2}$ solubility was studied and found to be consistent with the trends reported for (alkanol)amines. A concentration-based chemical equilibrium model was developed and used to represent the experimental vapour-liquid equilibrium (VLE) data (for a system without precipitation). In spite of the numerical simplicity of the model, a reasonable good description of the single acid gas-amine equilibria could be observed. The equilibrium constant of the carbamate hydrolysis for potassium salt of L-proline was calculated by the VLE model. The carbamate of L-prolinate salt is more stable towards hydrolysis than a typical secondary amine (e.g. DEA), more in the range of primary amines or -amino acid salts. In addition, the heat of reaction of $\mathrm{CO}_{2}$ in L-prolinate solutions was estimated using the solubility data. The value of this parameter is close to those reported for other amino acids (e.g. glycine), slightly higher than for MDEA and lower when compared to MEA. This heat of reaction is an important factor in the thermal energy requirements of acid gas treating through its indirect influence on a temperature sensitivity of the VLE curves. However, to perform the complete energetic evaluation of this system, other terms (besides the heat of reaction) contributing to the reboiler duty will have to be taken into account.

In the final chapter, a comprehensive estimation method to calculate the reboiler duty is presented with a new approach of establishing the $\mathrm{H}_{2} \mathrm{O}: \mathrm{CO}_{2}$ overhead (reflux-) ratio; which is, next to the heat of reaction, the most important parameter in this type of calculations. The reboiler duty for stripping $\mathrm{CO}_{2}$ from aqueous $5 \mathrm{~mol} \cdot \mathrm{dm}^{-3}$ MEA solution was calculated with the method developed in the present work and compared with data obtained in the working Aspen Plus Example (Aspen Plus v8.o). A good agreement between the data generated by both methods could be found. The vapour-liquid equilibrium data, with and without $\mathrm{CO}_{2}$ in the system, are needed in these calculations. The $\mathrm{CO}_{2}$ solubility in 3 and $4 \mathrm{~mol} \cdot \mathrm{dm}^{-3}$ aqueous solutions of potassium salt of L-proline was measured in the $\mathrm{CO}_{2}$ partial 
pressure range of 3.0 to $358 \mathrm{kPa}$. The experimental methods used were validated by measuring the $\mathrm{CO}_{2}$ solubility in $3 \mathrm{~mol} \cdot \mathrm{dm}^{-3}$ aqueous potassium sarcosinate solutions for the $\mathrm{CO}_{2}$ partial pressure range of 3.3 to $253 \mathrm{kPa}$. For both amino acids, the experiments were carried out at temperatures of 363,393 and $403 \mathrm{~K}$. The vapour pressures of both solvents were determined at temperatures from 353 to $403 \mathrm{~K}$. The energy requirements for potassium salt of L-proline was calculated and compared with the literature numbers reported for other amino acid salts. As found, the reboiler duty of potassium L-prolinate is slightly higher than that for the $5 \mathrm{M}$ MEA reference system and is within the range reported for other amino acid salts. The value of the reboiler duty reduces, however, with increasing rich $\mathrm{CO}_{2}$ liquid loading. Further increase in the rich loading by, for example, precipitation may bring energy savings in amino acid salt-based $\mathrm{CO}_{2}$ absorption systems.

As reported in Chapter 3, precipitation is encountered when absorbing $\mathrm{CO}_{2}$ in $3 \mathrm{~mol} \cdot \mathrm{dm}^{-3}$ L-prolinate solutions at $285 \mathrm{~K}$ and above $6 \mathrm{kPa}$ of $\mathrm{CO}_{2}$; leading to higher loadings of the solvent at the same partial pressure of $\mathrm{CO}_{2}$. For L-prolinate, at a certain solution loading, the corresponding $\mathrm{CO}_{2}$ partial pressure is up to half the (extrapolated) value when assuming that no precipitation takes place. Precipitation upon $\mathrm{CO}_{2}$ absorption might create new possibilities for the (temporarily) storage of $\mathrm{CO}_{2}$. As example, the $\mathrm{CO}_{2}$ captured and precipitated as a solid bicarbonate salt could be used as a feedstock for algae culture.

The potential of L-proline and other (precipitating) amino acid salt solutions for $\mathrm{CO}_{2}$ capture and utilization is still not fully explored and deserves further consideration. 


\section{Samenvatting}

Reactieve absorptie is een veelvoorkomend proces in de chemische industrie, onder andere bij de behandeling van $\mathrm{CO}_{2}$ bevattende industriële afgasstromen. Voor het verwijderen van $\mathrm{CO}_{2}$ uit industriële gassen door middel van chemische absorptie, worden over het algemeen waterige oplossingen van (alkanol)amines zoals MEA, DGA, DEA, MDEA en DIPA (of mengsels met of zonder "activators" zoals piperazine) gebruikt. In principe kunnen deze systemen worden gebruikt voor het verwijderen van het broeikasgas $\mathrm{CO}_{2}$ uit rookgassen, zoals van energiecentrales. Echter, deze oplosmiddelen hebben verscheidene nadelen zoals een beperkt cyclische $\mathrm{CO}_{2}$ laadvermogen, wat resulteert in hoge energiekosten voor regeneratie. Tevens dragen zij (zonder tegenmaatregelen) bij aan een relatief hoge corrosiesnelheid van procesapparatuur en zijn ze gevoelig voor degradatie in een zuurstofrijke atmosfeer, resulterend in toxische afbraakproducten.

Waterige alkalische aminozuur zoutoplossingen kunnen een veelbelovend alternatief zijn voor de conventionele waterige (alkanol) amine oplossingen. In het algemeen worden aminozuur zoutoplossingen gekenmerkt door een hogere stabiliteit tegen oxidatieve degradatie en door een goede biologische afbreekbaarheid, gecombineerd met een lage toxiciteit en een viscositeit en oppervlaktespanning vergelijkbaar met water. Dit laatste is met name van belang in het geval van membraangas absorptie processen. Ze bieden ook de mogelijkheid om een vast product te precipiteren bij het opnemen van $\mathrm{CO}_{2}$, vooral voor oplossingen met hoge aminozuur zoutconcentratie en hoge $\mathrm{CO}_{2}$ belading van de vloeistoffase. Hoewel aminozuurzouten in een aantal industriële toepassingen zijn toegepast, was informatie over deze systemen slechts beperkt beschikbaar. Het hier gepresenteerde werk was onderdeel van een groter project met als doel om nieuwe, op aminozuur zout gebaseerde oplosmiddelen voor $\mathrm{CO}_{2}$ absorptie uit rookgas te evalueren.

Met behulp van een "smart screening" methode, is het precipitatiegebied (of "werkbereik") bepaald voor een reeks van aminozuurzouten (te weten taurine, sarcosine, L-proline, $\beta$-alanine, 6-aminohexaanzuur en DL-methionine) voor het $\mathrm{CO}_{2}$ absorptieproces onder verschillende omstandigheden bij gevarieerde temperatuur, $\mathrm{CO}_{2}$ partiaaldruk en oplosmiddelconcentratie. Voor alle bestudeerde aminozuur zoutoplossingen, behalve voor DL-methionine, kan een betrekkelijk groot werkbereik zonder precipitatie worden waargenomen. De overgangszone van niet-precipiterende naar precipiterende condities 
bleek een sterke functie van de operationele procescondities. Bij constante temperatuur verschuift de precipitatiegrens naar lagere $\mathrm{CO}_{2}$ partiaaldruk bij toenemende aminozuur zoutconcentratie. $\mathrm{Bij}$ constante $\mathrm{CO}_{2}$ partiaaldruk, verschuift deze grens naar hogere concentraties oplosmiddel bij toenemende temperatuur, als gevolg van zowel de invloed van de absorptietemperatuur als ook van de chemische samenstelling in de vloeistoffase op de oplosbaarheidsproducten van de precipitaten. De identiteit van de gevormde precipitaten was onderzocht en onthuld en ook hun visuele verschijning is beschreven. Dit laatste aspect kan van groot operationeel belang zijn, b.v. met betrekking tot het verpompen van de gevormde slurrie. Sommige slurries zijn gemakkelijk opnieuw te suspenderen, terwijl in andere systemen gels of netwerken gevormd worden die mogelijk procesapparatuur kunnen verstoppen. Gevonden werd dat voor alkalische zouten van taurine en DL-methionine de aminozuren zelf (als zwitterion) precipiteren bij verzadiging van de oplossing met $\mathrm{CO}_{2}$, terwijl voor L-proline, $\beta$-alanine, sarcosine en 6-aminohexaanzuur vaste stoffen worden gevormd die $\mathrm{CO}_{2}$ bevatten. In het laatste geval, creëert de hoge oplosbaarheid van het zwitterion in combinatie met een hoge base sterkte van de oplossing gunstige voorwaarden voor het neerslaan van een bicarbonaatzout; waarvoor geen eerdere melding in de literatuur kon worden gevonden. Evenwichtsmetingen voor $\mathrm{CO}_{2}$ absorptie-desorptie zijn uitgevoerd voor $1 \mathrm{~mol} \cdot \mathrm{dm}^{-3}$ aminozuur zoutoplossingen in water. Onder deze omstandigheden, hadden de geteste aminozuurzouten een vergelijkbare cyclische capaciteit (vastgesteld als het verschil in $\mathrm{CO}_{2}$ oplosbaarheid bij 313 en $373 \mathrm{~K}$ ) met de industriële standaard MEA, maar hiervan vertoonden alleen L-proline en sarcosine (volgens literatuur) een hogere reactiviteit met $\mathrm{CO}_{2}$. Op basis van de resultaten in deze studie, is het alkalisch zout van het iminozuur L-proline gekozen voor nader onderzoek in dit proefschrift. Voor deze stof zijn de belangrijkste kenmerken ter evaluatie van dit oplosmiddel voor $\mathrm{CO}_{2}$ verwijdering uit rookgas, zoals de fysisch-chemische eigenschappen, de $\mathrm{CO}_{2}$ absorptiekinetiek, thermodynamische evenwichten en het energieverbruik voor de regeneratie van het oplosmiddel bepaald.

De reactiekinetiek van $\mathrm{CO}_{2}$ in waterige oplossingen van kalium L-prolinaat werd bepaald in een geroerde cel reactor met een vlak, geometrisch bepaald, gas-vloeistof grensvlak voor het concentratie bereik van $0.5-3 \mathrm{~mol} \cdot \mathrm{dm}^{-3}$ en in het temperatuur bereik van $290-303 \mathrm{~K}$. Om het effect van kalium ten opzichte van natrium als kation te vergelijken, werd de absorptiesnelheid van $\mathrm{CO}_{2}$ in waterige oplossingen van het natriumzout van L-proline gemeten bij $298 \mathrm{~K}$, voor dezelfde reeks van concentraties. De experimenteel verkregen reactieve absorptie fluxen zijn vertaald, met behulp van de pseudo-eerste orde benadering, naar intrinsieke reactiekinetiek. De reactieorde ten opzichte van het aminozuur, uitgaande van machtswet kinetiek, bleek tussen 1.40 en 1.44 te liggen voor beide behandelde zouten. Deze waarde wijst op aanzienlijke bijdragen van zowel L-prolinaat als van water aan de deprotonering van het zwitterion. In termen van reaktiekinetiek, laat het kaliumzout van 
L-proline gemiddeld een $32 \%$ hogere reactiviteit naar $\mathrm{CO}_{2}$ zien dan het natrium equivalent; bovendien reageert het sneller dan de meeste conventionele (alkanol)amines en aminozuur zouten. De tweede orde reaktiesnelheidsconstante, $k_{2}$, is bepaald op $93 \cdot 7 \cdot 10^{3} \mathrm{dm}^{3} \cdot \mathrm{mol}^{-1} \cdot \mathrm{s}^{-1} \mathrm{bij}$ $298 \mathrm{~K}$, met een activeringsenergie van $43.3 \mathrm{~kJ} \cdot \mathrm{mol}^{-1}$. Kalium L-prolinaat kan daarom aantrekkelijk zijn in bulk $\mathrm{CO}_{2}$ afvang, hetzij als zelfstandig oplosmiddel danwel als kinetische promotor voor andere hoge capaciteit, lage energiebehoefte oplosmiddelen.

Complementair aan de absorptiesnelheidsdata, werden de dichtheid en de dynamische viscositeit van oplossingen van kalium, natrium en lithium zouten van L-proline bepaald in het temperatuurbereik van $284-313 \mathrm{~K}$, voor concentraties van $0.1 \mathrm{~mol} \cdot \mathrm{dm}^{-3}$ tot de maximale concentratie, zoals vastgesteld tijdens de aminozuur zouten screening activiteiten, beschreven in hoofdstuk 2 van dit proefschrift. Om de fysische oplosbaarheid van $\mathrm{CO}_{2}$ in de aminozuur zoutoplossingen te schatten, hetgeen essentieel is voor het afleiden van reaktiekinetiek, is de analogie met het niet-reactieve $\mathrm{N}_{2} \mathrm{O}$ gebruikt en derhalve is de oplosbaarheid van $\mathrm{N}_{2} \mathrm{O}$ in waterige L-prolinaat oplossingen (kalium en natriumzouten) gemeten. Voor een reeks van condities, temperaturen 284-313 K en oplossing concentraties van 0,1 tot $3 \mathrm{~mol} \cdot \mathrm{dm}^{-3}$, werd het kenmerkende "uitzout" gedrag gevonden.

De absorptiecapaciteit ("oplosbaarheid") van $\mathrm{CO}_{2}$ in waterige kalium zoutoplossingen van L-proline werd gemeten over een brede range van condities relevant voor $\mathrm{CO}_{2}$ afvangst uit rookgas; bij temperaturen van $285-323 \mathrm{~K}$, bij concentraties van 0.5 tot $3 \mathrm{~mol} \cdot \mathrm{dm}^{-3}$ en bij een partiële druk voor $\mathrm{CO}_{2}$ tot $70 \mathrm{kPa}$. Het effect van oplosmiddelconcentratie, de temperatuur en $\mathrm{CO}_{2}$ partiaaldruk op de totale $\mathrm{CO}_{2}$ oplosbaarheid werd consistent bevonden met trends gerapporteerd voor de oplosbaarheid in (alkanol)amine oplossingen. Een op concentraties gebaseerd chemisch evenwichtsmodel is in deze studie ontwikkeld en gebruikt om de experimentele damp-vloeistof evenwichtsgegevens (VLE) te representeren (voor een systeem zonder neerslag). Ondanks de numerieke eenvoud van het model is een goede beschrijving van de gas-vloeistof evenwichten verkregen. Uit de data is de evenwichtsconstante van de carbamaathydrolyse van het kalium zout van L-proline berekend met het VLE model. Het carbamaat van het L-prolinaat zout is stabieler bij/tijdens hydrolyse dan een gemiddeld secundair amine (bijvoorbeeld DEA), en deze stabiliteit is meer vergelijkbaar met primaire amines of -aminozuur zouten. Daarnaast werd de reactiewarmte van $\mathrm{CO}_{2}$ in L-prolinaat oplossingen afgeschat vanuit de verkregen oplosbaarheidsdata. De waarde van deze parameter ligt dichtbij die gerapporteerd voor andere aminozuren (bijvoorbeeld glycine) en is iets hoger dan MDEA en lager dan in MEA. Deze reaktiewarmte is een belangrijke factor in de bepaling van de thermische energievereisten voor $\mathrm{CO}_{2}$ verwijdering uit rookgas vanwege de indirecte invloed op de temperatuur gevoeligheid van de VLE curves. Om een volledige energetische evaluatie van zo'n $\mathrm{CO}_{2}$ afvangsysteem gebaseerd op het gebruik van L-proline te kunnen uitvoeren, zal 
naast de reactiewarmte ook rekening moeten worden gehouden met andere termen die bijdragen aan het benodigde vermogen in de reboiler van de regeneratiekolom.

In het laatste hoofdstuk wordt derhalve een schattingsmethode voor het berekenen van het vermogen in de reboiler gepresenteerd, inclusief een nieuwe aanpak voor het verkrijgen van de $\mathrm{H}_{2} \mathrm{O}: \mathrm{CO}_{2}$ overhead (reflux-) verhouding. Deze verhouding is, naast de reactiewarmte, de belangrijkste parameter in dergelijke berekeningen. Het benodigde vermogen in de reboiler voor het strippen van $\mathrm{CO}_{2}$ uit een waterige $5 \mathrm{~mol} \cdot \mathrm{dm}^{-3}$ MEA oplossing werd berekend met de methode ontwikkeld in het huidige werk en vergeleken met de resultaten van een voorbeeldtoepassing uit het flowsheet pakket Aspen Plus (Aspen Plus v8.o), waarbij een goede overeenkomst tussen de door beide methoden gegenereerde gegevens werd gevonden. Voor de berekeningsmethode is kennis van het damp-vloeistof evenwicht nodig, met en zonder $\mathrm{CO}_{2}$ in het systeem. De oplosbaarheid van $\mathrm{CO}_{2}$ in 3 en $4 \mathrm{~mol} \cdot \mathrm{dm}^{-3}$ oplossingen van het kalium zout van L-proline werd gemeten over het $\mathrm{CO}_{2}$ partiaaldruk gebied van 3.0 tot $358 \mathrm{kPa}$. De experimentele methode werd gevalideerd met metingen van de $\mathrm{CO}_{2}$ oplosbaarheid in een $3 \mathrm{~mol} \cdot \mathrm{dm}^{-3}$ waterige kalium sarcosinaat oplossing voor $\mathrm{CO}_{2}$ partiaaldrukken van 3.3 tot $253 \mathrm{kPa}$. Voor beide aminozuur zoutoplossingen werden de experimenten uitgevoerd bij temperaturen van 363, 393 en 403 K. De dampspanningen van de onbeladen oplossingen werden bepaald bij temperaturen van 353 tot $403 \mathrm{~K}$. De uiteindelijke energiebehoefte voor regeneratie van beladen oplossingen van het kalium zout van L-proline is berekend en vergeleken met de literatuurwaarden gerapporteerd voor andere aminozuur zouten. Uit de resultaten blijkt dat het vermogen in de reboiler bij kalium L-prolinaat iets hoger is dan voor het 5 M MEA referentiesysteem en in het gebied ligt zoals gevonden voor andere aminozuur zouten. Het benodigde vermogen van de reboiler voor regeneratie vermindert echter sterk met toenemende $\mathrm{CO}_{2}$ belading. Een verdere verhoging van de belading bij absorptie, door bijvoorbeeld precipitatie, zou daarom verder energiebesparingen kunnen opleveren voor op aminozuur zout gebaseerde $\mathrm{CO}_{2}$ absorptie systemen.

Zoals gemeld in hoofdstuk 3, wordt een neerslag gevonden bij het absorberen van $\mathrm{CO}_{2}$ in $3 \mathrm{~mol} \cdot \mathrm{dm}^{-3}$ L-prolinaat oplossingen bij $285 \mathrm{~K}$ en boven $6 \mathrm{kPa}$ van $\mathrm{CO}_{2}$; hetgeen leidt tot hogere ladingen van het oplosmiddel bij dezelfde partiaaldruk $\mathrm{CO}_{2}$. In dit gebied is voor L-prolinaat, bij een bepaalde oplossingsbelading, de overeenkomstige $\mathrm{CO}_{2}$ partiaaldruk tot de helft van de (geëxtrapoleerde) waarde, wanneer aangenomen dat precipitatie niet plaatsvindt. Neerslag tijdens $\mathrm{CO}_{2}$ absorptie kan wellicht nieuwe toepassingsmogelijkheden creëren voor de (tijdelijke) opslag van $\mathrm{CO}_{2}$. De $\mathrm{CO}_{2}$, afgevangen en neergeslagen als een vaste stof in de vorm van een bicarbonaatzout, kan bijvoorbeeld worden gebruikt als grondstof voor algencultuur. 
Het potentieel van L-proline en andere neerslag vormende aminozuur zoutoplossingen voor $\mathrm{CO}_{2}$ afvang en hergebruik is nog niet volledig onderzocht en verdient nadere overweging. 



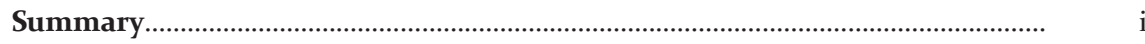

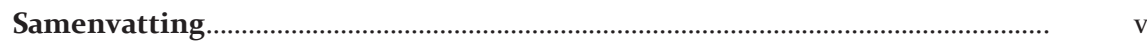

1 General Introduction..............................................................................................

${ }_{1.1}$ Carbon dioxide capture...............................................................................................

1.2 Solvent based $\mathrm{CO}_{2}$ capture processes.....................................................................

1.3 Amino acid salts systems....................................................................................

1.4 General introduction to this thesis........................................................................... 6

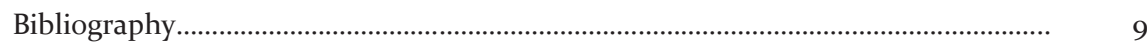

2 Screening Amino Acid Salt Solutions for Post-Combustion Carbon 11

Dioxide Capture

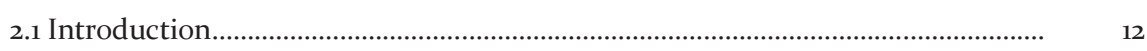

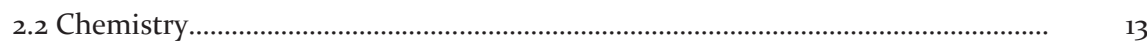

2.3 Experimental section.........................................................................................

2.4 Results and discussion................................................................................................ 17

2.4.1 Precipitation in $\mathrm{CO}_{2}$-AAS- $\mathrm{H}_{2} \mathrm{O}$ absorption systems............................................ 17

2.4.2 Absorption kinetics............................................................................................. 22

2.4.3 Absorption capacity and regeneration screening................................................. 22

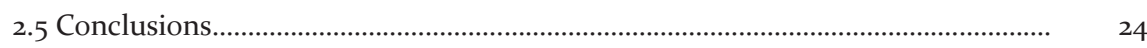

Appendix.............................................................................................................. 25

A.1 Operating window and physical properties........................................................... 25

A.2 Identification of the solid phase............................................................................. 27

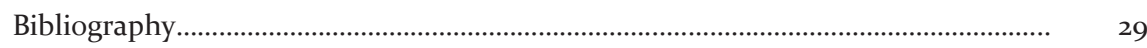

3 Solubility of Carbon Dioxide in Aqueous Potassium L-Prolinate Solutions 33

- Absorber Conditions

3.1 Introduction ......................................................................................................

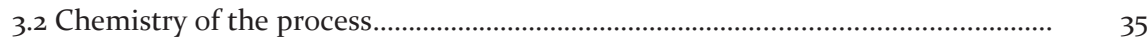


3.3 Equilibrium model...............................................................................................

3.4 Experimental section.............................................................................................

3.5 Results and discussion............................................................................................ 42

3.6 Conclusions ............................................................................................................. 53

Nomenclature..................................................................................................... 55

Bibliography ......................................................................................................... 56

4 Reactive Absorption of Carbon Dioxide in L-Prolinate Salt Solutions.......... 61

4.1 Introduction ........................................................................................................... 62

4.2 Reaction mechanism................................................................................................... 63

4.3 Mass transfer...................................................................................................... 65

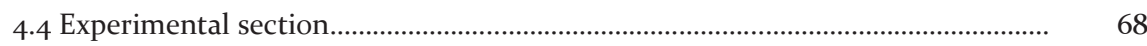

4.5 Results and discussion............................................................................................. 69

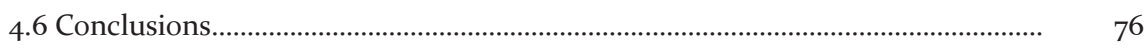

Nomenclature.......................................................................................................

Appendix.................................................................................................................. $\quad 79$

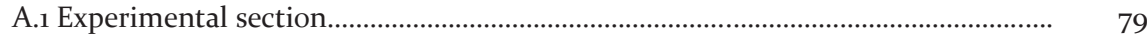

A.2 Results and discussion..................................................................................... 80

Bibliography ............................................................................................................. 85

5 Amino Acid Salts for Carbon Dioxide Capture - Evaluating L-Prolinate at $\quad 89$ Desorber Conditions

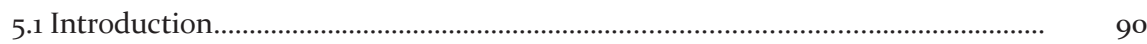

5.2 Material and methods........................................................................................... 92

5.3 Reboiler duty ................................................................................................... 92

5.4 Results and discussion........................................................................................ 97

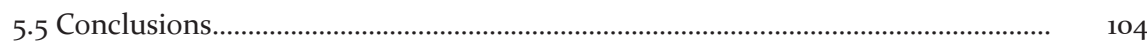

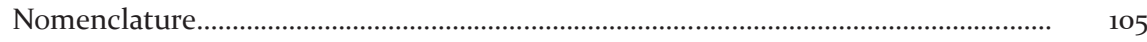

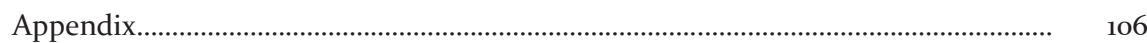

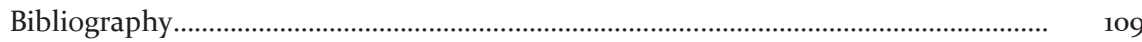

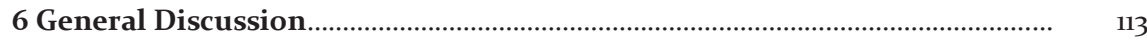

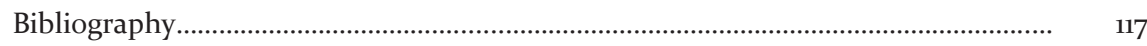

Acknowledgements............................................................................................... 


\section{Chapter 1}

\section{General Introduction}

\subsection{Carbon dioxide capture}

The removal of carbon dioxide $\left(\mathrm{CO}_{2}\right)$ from a process gas stream is an important step in many industrial processes and can be required for operational, economical and/or environmental reasons. In an aqueous environment, $\mathrm{CO}_{2}$ can react with water to form a weak acid known as carbonic acid which lowers the $\mathrm{pH}$ of water and promotes corrosion of industrial equipment. Carbon dioxide is also a common impurity in natural gas streams and must often be removed to a large extent to meet the heating value requirements of the gas or to meet pipeline specifications. Other examples can be found in the production of liquefied natural gas (LNG), where $\mathrm{CO}_{2}$ must be removed to prevent freezing in the lowtemperature chillers, and in the manufacture of ammonia, where small amounts of $\mathrm{CO}_{2}$ can act as a poison to the catalytic process (Kohl and Nielsen, 1997). Finally, $\mathrm{CO}_{2}$ as a major greenhouse gas is held responsible for the observed global warming over the past decades and the concerns for related climate change and its possible effect on mankind. In general, technologies to separate $\mathrm{CO}_{2}$ from gas streams are based on absorption, adsorption, membranes or other physical, chemical and biological separation methods. In the present work, absorption with reactive solvents is considered for post-combustion $\mathrm{CO}_{2}$ capture from flue gas.

\subsection{Solvent based $\mathrm{CO}_{2}$ capture processes}

Industrially, solvent-based $\mathrm{CO}_{2}$ capture processes have been operated for many years. In Figure 1.1 below a typical flow scheme of $\mathrm{CO}_{2}$ recovery using chemical solvents is shown. The feed gas, in principle either a process stream or flue gas, is passed upward through an absorber column, where it is brought in contact with a counter-current stream of reactive absorbent. For post-combustion of $\mathrm{CO}_{2}$ from flue gases from a power plant, normally the flue gas is slightly pressurized and cooled after the desulfurization step upstream, before entering the absorber. In the absorber, at temperatures typically between 
313 and $333 \mathrm{~K}$, the solution is gradually saturated, while flowing downward, with $\mathrm{CO}_{2}$, until it leaves the absorber at the bottom as the so-called "rich" solvent. The treated gas stream leaves the absorber at the top, where it can be further processed or emitted to the atmosphere. The rich solvent from the bottom of the absorption column is heated by exchanging heat with the lean solution from the bottom of the stripping column, and is then fed near the top of the stripping column. In the desorber, the chemically bonded $\mathrm{CO}_{2}$ is stripped from the solvent. The regeneration of the chemical solvent is carried out at elevated temperatures (373-413 K) and pressures slightly higher than atmospheric pressure. Heat is supplied to the reboiler to maintain the regeneration conditions. This leads to a thermal energy penalty as a result of the required heating of the solvent, providing the required desorption heat for removing the chemically bonded $\mathrm{CO}_{2}$ and for the evaporation of water as the steam produced in the reboiler that acts as the stripping gas. Steam is recovered in the condenser at the top of the column and fed back to the stripper. The lean solution from the stripper, containing far less $\mathrm{CO}_{2}$, and after partial cooling in the "lean-torich heat exchanger" is passed through a particle filter (sometimes a carbon filter as well) and further cooled by a heat exchange with water or air, and subsequently fed to the top of the absorber. In this way, the absorption liquid cycles between the absorber and the regenerator. The gas from the top of the regenerator is cooled to condense the water vapour, leaving a nearly pure $\mathrm{CO}_{2}$ stream behind. The condensate (or a major portion of it) collected from the acid gas is fed back to the system to prevent the solvent from becoming progressively more concentrated. A high purity $\mathrm{CO}_{2}$ gas stream (>99\%) leaves the desorber and is further processed to be used, for example, in greenhouses, for the (underground) storage or reuse as a chemical feedstock.

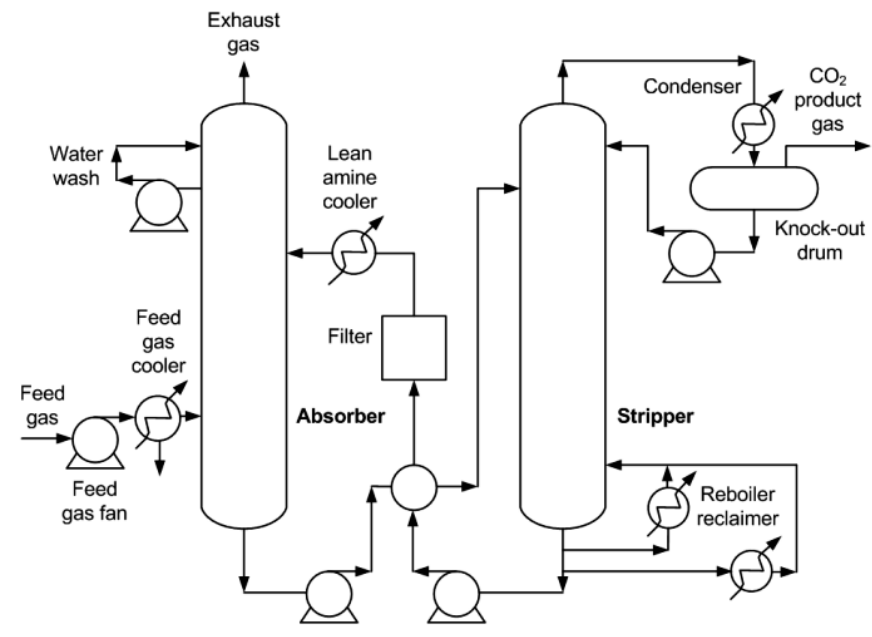

Figure 1.1: Process flow diagram for $\mathrm{CO}_{2}$ removal with chemical solvent (Kohl and Nielsen, 1997) 
Separation of $\mathrm{CO}_{2}$ by using reactive solvents is considered as the most cost effective and operationally mature technology available for low pressure, post-combustion flue gas. (Alkanol)amines which are of industrial importance are monoethanolamine (MEA), diethanolamine (DEA), diisopropanolamine (DIPA), N-methyldiethanolamine (MDEA), diglycolamine (DGA) and their mixtures (with or without "activators" such as piperazine). An overview of characteristics of commercially available (alkanol)amines can be found in Bailey and Feron (2005). The cost of acid gas absorption using aqueous solutions of (alkanol)amines is, however, still considered to be relatively high and is caused by:

- High solvent consumption. This is caused by high evaporation rates and thermal and oxidative degradation of (alkanol)amines. Solvents with high vapor pressure (e.g. MEA) can lead to significant volatility losses in the low pressure amine contactors. Thermal and oxidative instability of these solvents results in toxic degradation products, which are formed as a result of the side reactions with $\mathrm{CO}_{2}$, $\mathrm{NO}_{\mathrm{x}}$, oxygen and other minor contaminants.

- Equipment corrosion. These absorption liquids are subject to corrosion by $\mathrm{CO}_{2}$ and $\mathrm{H}_{2} \mathrm{~S}$ in the vapour phase, in the amine solution (by amine degradation products) and in the regenerator reflux (Kohl and Nielsen, 1997). This can result in the production losses and reduced equipment life time. Corrosion problems impact directly on the plant's economy by forcing the use of more expensive materials of construction.

- High energy consumption for solvent regeneration. Primary and secondary aminoalcohols are characterized by relatively stable carbamate complexes and high heats of reaction, which translates into high energy requirements for solvent regeneration.

- Limited $\mathrm{CO}_{2}$ absorption rates and loading capacity. (Alkanol)amine-based systems which are characterized by higher rates of absorption are often limited by poorer working capacity; see Bailey and Feron (2005). The working (cyclic-) capacity determines the required solvent circulation rate, which on its turn has a major influence on both equipment size and energy consumption. The reaction rate determines the size of equipment, especially for the absorber. Both parameters have a crucial impact on the investment costs of the plant.

- Environmental concerns. More recently, with major applications of this class of solvents for $\mathrm{CO}_{2}$ capture at power plants being considered, environmental and toxicological aspects are gaining attention. Commercially used (alkanol)amines are characterized by a low biodegradability and the eco-toxicological character. Emissions of these compounds and degradation products thereof (especially nitrosamines) may occur through the clean exhaust gas as a degraded solvent or 
an accidental spill and this can have a strong environmental impact (EideHaugmo et al., 2009).

\subsection{Amino acid salts systems}

Various novel solvents have been investigated with the objective of achieving reduced energy consumption for solvent regeneration and eliminating the (operational) difficulties as encountered for (alkanol)amine-based $\mathrm{CO}_{2}$ removal systems. Among them, amino acids (salts) have drawn attention in recent years at both the academic and commercial level. Table 1.1 presents an overview of commercial, patented processes using amino acids and their alkaline salts in post-combustion capture.

Based on the (pilot) plant experiences, it has been demonstrated that amino acids (salts) offer possibilities for developing an acid gas scrubbing process based on less corrosive, more stable and competitive (when compared to commercially used (alkanol)amines) absorbents. This is illustrated, for example, in the Giammarco-Vetrocoke process where alkanolamine (DEA) and (more environmental attractive, nontoxic) amino acid (glycine) were used alternatively to activate alkali carbonate solutions. Performance of both processes (activated with two different promoters) was compared. As a result, higher absorption rates (in particular) and better overall efficiency with less steam required for solvent regeneration was found for a glycine-activated solution compared to the one activated by DEA (Kohl and Nielsen, 1997). Better characteristics compared to amino-alcohols were found also for Alkacid solvents (BASF). These absorption liquids showed better selectivity towards a specific acid gas $\left(\mathrm{H}_{2} \mathrm{~S}, \mathrm{CO}_{2}\right)$, higher absorption capacity and required less steam for regeneration of the solvent compared to, for example, DEA and MDEA. This was especially pronounced for the "dik" solution. In addition, these solvents proved to be quite stable and relatively noncorrosive (Kohl and Nielsen, 1997). Siemens AG has developed a proprietary post-combustion carbon capture technology (POSTCAP) based on aqueous amino acid salt solutions (Schneider and Schramm, 2011). TNO (the Netherlands) proposed two $\mathrm{CO}_{2}$ separation processes using aqueous alkaline salts of amino acids as reactive solvents. The membrane gas absorption (MGA) process is based on the use of commercially available polypropylene hollow fibre membranes. Whereas conventional absorption liquids like alkanolamines were not- or less compatible with these membranes, the new CORAL liquids $\left(\mathrm{CO}_{2}\right.$ Removal Absorption Liquid), essentially aqueous solutions of potassium salts of certain amino acids, have shown stable operation with the considered membrane modules because of higher liquid surface tension when compared to conventional aqueous alkanolamines. Some of these new absorbents exhibit as well as an excellent oxygen resistance and have negligible vapour pressure, which reduces significantly chemical losses 
(Feron and ten Asbroek, 2004; Goetheer and Nell, 2009). The DECAB process takes an advantage of the fact that when absorbing $\mathrm{CO}_{2}$ in alkaline salts of amino acids at some point (for certain liquid $\mathrm{CO}_{2}$ loading and solvent concentration) a precipitate will be formed. According to literature, the precipitate can be the amino acid itself (Kumar et al., 2003), but it can consist as well of carbonate species as was reported by Hook (1997). Furthermore, it has been shown that as a result of such precipitation the $\mathrm{CO}_{2}$ equilibrium partial pressure over the resulting slurry will remain (approximately) constant for a certain solution loading. This gave a possibility of higher loadings of the solvent, which has benefits for both the solvent circulation and thermal energy requirements for solvent regeneration. In addition, it is claimed that as higher driving force is observed the absorber size could be essentially reduced. In this three-phase $\mathrm{CO}_{2}$ separation process, spray tower was chosen over other types of contactors to avoid possible equipment blockage (Feron and Asbroek, 2004; Fernandez and Goetheer, 2011). The recently developed TNO-DECAB Plus process exploits an extra driving force for $\mathrm{CO}_{2}$ stripping caused by a reduction of the solution $\mathrm{pH}$ due to precipitation (Sanchez Fernandez et al., 2013). The CASPER process by the iCAP consortium applies precipitation in the $\mathrm{CO}_{2}$-saturated amino acid salt solution ( $\beta$-alanine) for a simultanous separation of $\mathrm{CO}_{2}$ and $\mathrm{SO}_{2}$ from flue gas.

Table 1.1: Amino acid salts in post-combustion acid gas capture - process overview

\begin{tabular}{llll}
\hline Process/Licenser & Solvent & Application & Source \\
\hline Giammarco- & Hot alkali carbonate & Process applied for bulk $\mathrm{CO}_{2}$ & Kohl \& Nielsen \\
Vetrocoke & solutions promoted with & removal from high pressure & $(1997)$ \\
Process & organic activators (e.g. & streams and to produce $\mathrm{CO}_{2}$ & \\
[Commercial] & glycine) & of high purity & \\
\hline Alkacid Process & Alkacid solvents: "M" & Process used for selective & Kohl \& Nielsen \\
BASF & solution (sodium salt of & removal of $\mathrm{H}_{2} \mathrm{~S}$ and/or $\mathrm{CO}_{2}$ & $(1997)$ \\
[Commercial] & L-alanine), "dik" solution & from a variety of gas streams & \\
& (potassium salts of diethyl- & containing other acid & \\
& or dimethylglycine), "S" & impurities such as $\mathrm{CS}_{2}, \mathrm{HCN}$, & \\
& solution (sodium & NH ${ }_{3}$, dust, mercaptans and & \\
& phenolate) & tar, depending on the & \\
& & applied absorbent & \\
\hline
\end{tabular}


continued from previous page

\begin{tabular}{|c|c|c|c|}
\hline Process/Licenser & Solvent & Application & Source \\
\hline $\begin{array}{l}\text { MGA Process } \\
\text { TNO } \\
{[\text { Commercial }]}\end{array}$ & $\begin{array}{l}\text { CORAL Liquids: aqueous } \\
\text { alkaline salts of certain } \\
\text { amino acids (e.g. taurine, } \\
\text { glycine) }\end{array}$ & $\begin{array}{l}\text { Membrane gas absorption } \\
\text { process combining the } \\
\text { commercially available } \\
\text { polypropylene hollow fibre } \\
\text { membranes with amino acid } \\
\text { salt solutions, and used for } \\
\mathrm{CO}_{2} \text { removal from flue gas } \\
\text { streams }\end{array}$ & $\begin{array}{l}\text { Feron \& } \\
\text { ten Asbroek } \\
(2004) ; \\
\text { Goetheer \& } \\
\text { Nell (2009) }\end{array}$ \\
\hline $\begin{array}{l}\text { POSTCAP } \\
\text { Siemens AG } \\
{[\text { Commercial] }}\end{array}$ & $\begin{array}{l}\text { Aqueous potassium salts of } \\
\text { undisclosed amino acid }\end{array}$ & $\begin{array}{l}\text { Post-combustion } \mathrm{CO}_{2} \text { based } \\
\text { on amino acid salts. Further } \\
\text { process development will } \\
\text { include precipitation in } \\
\text { aqueous amino acid salts } \\
\text { solutions }\end{array}$ & $\begin{array}{l}\text { Schneider \& } \\
\text { Schramm } \\
(2011)\end{array}$ \\
\hline $\begin{array}{l}\text { DECAB Process } \\
\text { TNO } \\
\text { [Development] }\end{array}$ & CORAL Liquids & $\begin{array}{l}\text { The } \mathrm{CO}_{2} \text { separation process } \\
\text { based on the precipitating } \\
\text { amino acid salts }\end{array}$ & $\begin{array}{l}\text { Feron \& } \\
\text { ten Asbroek } \\
(2004) ; \\
\text { Fernandez \& } \\
\text { Goetheer } \\
(2011)\end{array}$ \\
\hline $\begin{array}{l}\text { DECAB Plus } \\
\text { TNO } \\
\text { [Development] }\end{array}$ & $\begin{array}{l}\text { Solvents under } \\
\text { development }\end{array}$ & $\begin{array}{l}\text { Process utilizes the } \mathrm{pH} \text { shift } \\
\text { induced by precipitation }\end{array}$ & $\begin{array}{l}\text { Sanchez } \\
\text { Fernandez } \\
\text { et al. (2013) }\end{array}$ \\
\hline $\begin{array}{l}\text { CASPER Process } \\
\text { iCAP } \\
\text { [Development] }\end{array}$ & $\begin{array}{l}\text { CASPER Solvent } \\
\text { ( } \beta \text {-alanine) }\end{array}$ & $\begin{array}{l}\text { Simultanous separation of } \\
\mathrm{CO}_{2} \text { and } \mathrm{SO}_{2} \text { from flue gas } \\
\text { based on precipitation in } \\
\text { amino acid salt solution }\end{array}$ & $\begin{array}{l}\text { Misiak et al. } \\
(2013)\end{array}$ \\
\hline
\end{tabular}

\subsection{General introduction to this thesis}

The current work was carried out within the Dutch national CCS program CATO. Within CATO, a project was initiated to assess new reactive solvents based on aqueous alkaline salts of amino acids for $\mathrm{CO}_{2}$ removal from industrial gas streams.

In the early stage of the project, a group of promising amino acid salts was selected for further evaluation, based on an initial screening effort, focusing on $\mathrm{CO}_{2}$ absorption kinetics (van Holst et al., 2009), $\mathrm{p} K_{a}$ values (Hamborg et al., 2007) and diffusivities (Hamborg et al., 20o8). The amino acid salts selected have included taurine, sarcosine, $\beta$-alanine, L-proline, 
DL-methionine and 6-aminohexanoic acid. In the present work, these reactive liquids were evaluated for their acid gas absorption-desorption potential and precipitation behaviour. Given the $\mathrm{CO}_{2}$ effective capacity, absorption kinetics, $\mathrm{p} K_{a}$ value and precipitation window, the (alkaline salt of) imino acid L-proline was chosen for further investigation. For this solvent, important characteristics such as physico-chemical properties, $\mathrm{CO}_{2}$ absorption kinetics, thermodynamic equilibria and energy consumption for solvent regeneration (reboiler duty) were determined.

In Chapter 2 a group of non-volatile amino acid salts (taurine, sarcosine, L-proline, DL-methionine, $\beta$-alanine and 6-aminohexanoic acid) is investigated to determine their potential as $\mathrm{CO}_{2}$ absorbents. Water solubility of these salts together with the relevant density and viscosity are given. The operating window for $\mathrm{CO}_{2}$ absorption with and without precipitation and the identity of the precipitates formed are reported. The acid gas capacity at absorption and desorption conditions is presented. The values determined together with the literature data on absorption kinetics (van Holst et al., 2009) and $\mathrm{p} K_{a}$ values (Hamborg et al., 2009) provide information about the use of these compounds as reactive solvents.

Chapter 3 describes the experimental determination of the solubility of $\mathrm{CO}_{2}$ in aqueous solutions of potassium L-prolinate at absorber temperatures. At certain operating conditions the precipitate is formed in the system. Vapour-liquid equilibrium (VLE) data (for situation without solids) are interpreted by a more conventional acid gas-amine equilibrium model. Also, the equilibrium constant of the carbamate hydrolysis for L-prolinate (as calculated by the model) and the enthalpy of absorption are reported and compared with the literature values found for (alkanol)amine-based $\mathrm{CO}_{2}$ absorbents.

Chapter 4 describes the experimental determination of absorption rate of $\mathrm{CO}_{2}$ into aqueous solutions of alkaline salts of L-proline at different amino acid salt concentrations, $\mathrm{CO}_{2}$ partial pressures and temperatures. The experimental reactive absorption fluxes are interpreted, using the pseudo-first order approach, into intrinsic reaction kinetics. Physicochemical properties such as density, viscosity, $\mathrm{N}_{2} \mathrm{O}$ solubility as needed in the kinetic data interpretation are also reported.

Chapter 5 describes the experimental determination of the $\mathrm{CO}_{2}$ solubility in aqueous solutions of potassium L-prolinate at desorber conditions. Limited number of VLE data is also reported for potassium sarcosinate (for validation of the experimental procedures). Vapour pressures for both solvents are reported. The reboiler duty for stripping $\mathrm{CO}_{2}$ from potassium L-prolinate solutions is approximated as the sum of three terms: the heat of desorption, the sensible heat and the heat of vaporization of amino acid salt solution, and compared with the numbers reported for MEA and other amino acid salts. A new approach 
to calculate the reflux factor, defined as the molar ratio of $\mathrm{H}_{2} \mathrm{O}: \mathrm{CO}_{2}$ in the regenerator overhead stream, is applied in the calculations of this regeneration energy.

Finally, a general discussion on the findings of this thesis and potential further work is presented. 


\section{Bibliography}

Bailey, D.W., Feron, P.H.M., 2005. Post-combustion decarbonisation processes. Oil and Gas Science and Technology - Rev. IFP 6o, 461-474

Eide-Haugmo, I., Brakstad, O.G., Hoff, K.A., Sørheim, K.R., Falck da Silva, E., Svendsen, H.F., 2009. Environmental impact of amines. Energy Procedia 1, 1297-1304

Fernandez, E.S., Goetheer, E.L.V., 2011. DECAB: Process development of a phase change absorption process. Energy Procedia 4, 868-875

Feron, P.H.M., Asbroek, N.A.M., 2004. New solvents based on amino-acid salts for $\mathrm{CO}_{2}$ capture from flue gases. GHGT-7, Vancouver, Canada

Goetheer, E.L.V., Nell, L., 2009. First pilot plant results from TNO's solvent development workflow. Carbon Capture Journal 8, 2-3

Hamborg, E.S., Niederer, J.P.M., Versteeg, G.F., 2007. Dissociation constants and thermodynamic properties of amino acids used in $\mathrm{CO}_{2}$ absorption from (293 to 353) K. Journal of Chemical Engineering Data 52, 2491-2502

Hamborg, E.S., van Swaaij, W.P.M., Versteeg, G.F., 2008. Diffusivities in aqueous solutions of the potassium salt of amino acids. Journal of Chemical and Engineering Data 53, 1141-1145

Van Holst, J., Versteeg, G.F., Brilman, D.W.F., Hogendoorn, J.A., 20o9. Kinetic study of $\mathrm{CO}_{2}$ with various amino acid salts in aqueous solution. Chemical Engineering Science 64, 59-68

Hook, R.J., 1997. An investigation of some sterically hindered amines as potential carbon dioxide scrubbing compounds. Industrial and Engineering Chemistry Research 36, 1779-1790

Kohl, A.L., Nielsen, R.B., 1997. Gas Purification: $5^{\text {th }}$ Edition. Gulf Publishing Company, Houston

Kumar, P.S., Hogendoorn, J.A., Timmer, J.S., Feron, P.H.M., 2003. Equilibrium solubility of $\mathrm{CO}_{2}$ in aqueous potassium taurate solutions: part 2. Experimental VLE data and model. Industrial and Engineering Chemistry Research 42, 2841-2852

Misiak, K., Sanchez Sanchez, C., van Os, P., Goetheer, E., 2013. Next generation post-combustion capture: combined $\mathrm{CO}_{2}$ and $\mathrm{SO}_{2}$ removal. Energy Procedia 37, 1150-1159

Sanchez Fernandez, E., Heffernan, K., van der Ham, L., Linders, M.J.G., Eggink, E., 2013. Conceptual design of a novel $\mathrm{CO}_{2}$ capture process based on precipitating amino acid solvents. Industrial and Engineering Chemistry Research 52, 12223-12235

Schneider, R., Schramm, H., 2011. Environmental friendly and economic carbon capture from power plant flue gases: The SIEMENS PostCap technology. First Post Combustion Capture Conference, Abu Dhabi 

Chapter 2

\section{Screening Amino Acid Salt Solutions for Post-Combustion Carbon Dioxide Capture}

The performance of a series of aqueous salts of non-volatile amino acids, as indicated by $\mathrm{CO}_{2}$ capacity, absorption kinetics, $\mathrm{p} K_{a}$ value, precipitation window, precipitate identity and appearance, viscosity, density and maximum solubility, has been studied and is presented in this work. Among the investigated amino acids were taurine, sarcosine, L-proline, $\beta$-alanine, 6-aminohexanoic acid and DL-methionine. The tendency of potassium salts of amino acids to form precipitates under varying operational conditions of $\mathrm{CO}_{2}$ absorption was studied at 293 and $313 \mathrm{~K}$, for $\mathrm{CO}_{2}$ partial pressures relevant to flue gas conditions and at atmospheric pressure $(101 \mathrm{kPa})$ and for amino acid concentrations in aqueous solution up to the solubility limit. Maximum solubility in water, relevant solvent density and viscosity of potassium salts of these amino acids were determined at $293 \mathrm{~K}$. A relatively broad window of operation without precipitation was found for the considered $\mathrm{CO}_{2}$ absorption systems (except for DL-methionine). The identity of the precipitates formed in alkaline (potassium, sodium and lithium) salts of amino acids has been revealed using $\mathrm{CHN}$ analysis and ${ }^{13} \mathrm{C}$ NMR. Based on the in-house observations and literature data, it was found that the solid product can exist in the form of amino acid, bicarbonate or (bi)carbonate salt of amino acid (salt). Equilibrium absorption-desorption experiments were carried out for $1 \mathrm{~mol} \cdot \mathrm{dm}^{-3}$ aqueous solutions. All tested amino acids showed a comparable cyclic capacity (derived as the difference between $\mathrm{CO}_{2}$ solubilities at 313 and $373 \mathrm{~K}$ ) to the industry standard MEA but only L-proline and sarcosine showed also higher $\mathrm{CO}_{2}$ absorption rate. With the results generated in this work, the most promising $\mathrm{CO}_{2}$ solvent candidates can be selected for further investigation. Based on the results of this study, the (alkaline salt of) imino acid L-proline was chosen for further investigation in this thesis.

\section{Parts of this chapter are published as:}

Majchrowicz, M.E., Brilman, D.W.F., Groeneveld, M.J., 2009; Precipitation regime for selected amino acid salts for $\mathrm{CO}_{2}$ capture from flue gases. Energy Procedia 1, 979-984 


\subsection{Introduction}

The climate change resulting from the increasing atmospheric concentration of greenhouse gases (GHGs) like $\mathrm{CO}_{2}, \mathrm{CH}_{4}, \mathrm{~N}_{2} \mathrm{O}$ and $\mathrm{CFCs}$ has become an unquestionable problem. Since the Kyoto protocol in December 1997, several stringent environmental regulations are proposed such as a target to reduce $20 \%$ of European greenhouse gases emissions by 2020 (EC, 2008). Among the GHGs, $\mathrm{CO}_{2}$ was identified as a major contributor to the global warming phenomenon and hence is a primary target for reduction. To avoid substantial increase in $\mathrm{CO}_{2}$ emissions over the next few decades, the development and deployment of technology options with a potential to decrease significantly emissions of this acid gas have been pursued. For the immediate future, post-combustion capture by use of chemical absorption with (alkanol)amines is the state-of-the-art solution to meet the exigent EC emission targets; as it can be retrofitted to already existing processes and power plants (Idem and Tontiwachwuthikul, 2006; Portugal et al., 2009). In this process, the acid gas is absorbed into an amine-based solution at lower temperatures and desorbed from the solution by heating to higher temperatures. The use of these absorption liquids is, however, accompanied by some complications such as solvent losses and amine-related emissions, caused by evaporation and solvent degradation in an oxygen-containing atmosphere (as encountered in flue gas), which results in toxic degradation products. In addition, the operational issues such as foaming and corrosion of the equipment has been reported (Goff and Rochelle, 2006; Supap et al., 2006).

In comparison with (alkanol)amines, aqueous solutions of amino acid salts (AAS) are biodegradable and show good resistance to oxidation (their natural habitat is an oxygencontaining environment). They have negligible volatilities (due to their ionic nature), and viscosities and surface tensions similar to water (Hook, 1997; van Holst et al., 2008, Weiland et al., 2010). Additionally, they react with $\mathrm{CO}_{2}$ in the same matter as amino-alcohols, which results in comparable or higher equilibrium capacities and absorption kinetics (van Holst et al., 2009, Kumar et al., 2003a). A further interesting feature of aqueous solutions of amino acid salts is their ability to form precipitates when absorbing $\mathrm{CO}_{2}$ (Hook, 1997; Kumar et al., 2003 b). It has been shown in literature that as a result of precipitation the equilibrium acid gas partial pressure over the resulting slurry remains fairly constant while increasing the solution loading. These higher solvent loadings may lead to lower energy consumption for solvent regeneration. Also, as the driving force is higher the size of gas-liquid contactor could be reduced (Feron and ten Asbroek, 2005). The chemical composition of different precipitates that are formed may create new possibilities for the (temporarily) storage of $\mathrm{CO}_{2}$ (Hook, 1997). 
When designing a new (regenerative) gas separation process for $\mathrm{CO}_{2}$ removal, utilizing the features of either precipitating or non-precipitating amino acid salt solution, knowledge is required on the operational window in order to know whether or not precipitation will occur within the process at the operating conditions under consideration. In the present work, the results are presented from an experimental investigation in which the operating conditions for $\mathrm{CO}_{2}$ absorption process (like absorption temperature, $\mathrm{CO}_{2}$ partial pressure and concentration of absorbent) are varied in order to determine the precipitation regime (or the "window of operation") for a series of non-volatile amino acid salts. The identity of the precipitates formed is investigated and revealed. Also, their visual appearance is characterized, which may be important, e.g., from a slurry handling point of view. In addition, (for the non-precipitating regime) the $\mathrm{CO}_{2}$ absorption-desorption cyclic capacity for the considered amino acid salts is determined. With the results generated in this work, an overview of the overall performance will be presented, indicated by $\mathrm{CO}_{2}$ capacity, absorption kinetics, $\mathrm{p} K_{a}$ value, precipitation window, precipitate identity and appearance, viscosity, density and maximum solubility. From this, the most promising candidates will be selected for further investigation.

\subsection{Chemistry}

Amino acids are amphiprotic species. They contain at least one basic carboxyl or sulphonyl group and one acidic amino group. In the absence of other solutes, amino acid exists in an aqueous solution as a zwitterion (form II in reaction 2.1). This compound has no overall electrical charge but it contains separate functional groups, which are positively and negatively charged. In solutions with ions other than those derived from the amino acid itself, the ionizable groups of am ampholyte might be electrically neutralized. The basic part of the zwitterion picks up a proton (form I in reaction 2.1) when an acid is added to the amino acid solution. Addition of a base to the zwitterion solution removes a proton from the ammonium group and leaves the molecule with a net negative charge (form III). It is this anion, with a deprotonated amino group, that reacts with acid gases such as $\mathrm{CO}_{2}$ and $\mathrm{H}_{2} \mathrm{~S}$.

$$
\begin{aligned}
& \mathrm{HO}_{2} \mathrm{CRNH}_{3}^{+} \stackrel{-\mathrm{H}^{+}}{\leftrightarrow}-{ }^{-} \mathrm{O}_{2} \mathrm{CRNH}_{3}^{+} \stackrel{-\mathrm{H}^{+}}{\leftrightarrow}{ }^{-} \mathrm{O}_{2} \mathrm{CRNH}_{2} \\
& \text { I II III }
\end{aligned}
$$

In aqueous solutions, $\mathrm{CO}_{2}$ reacts with primary and secondary amino acid salts according to the reaction scheme given in Figure 2.1. The initial absorption reaction is the formation of a zwitterion and a carbamate. The carbamate undergoes hydrolysis resulting in the formation of a deprotonated amino acid and a bicarbonate/carbonate (depending on the solution $\mathrm{pH}$ ). 
The deprotonated amino acid can then react with $\mathrm{CO}_{2}$. The equilibria in Figure 2.1 will favour the formation of a carbamate and a bicarbonate at lower temperatures and the liberation of an amino acid and $\mathrm{CO}_{2}$ at higher temperatures.

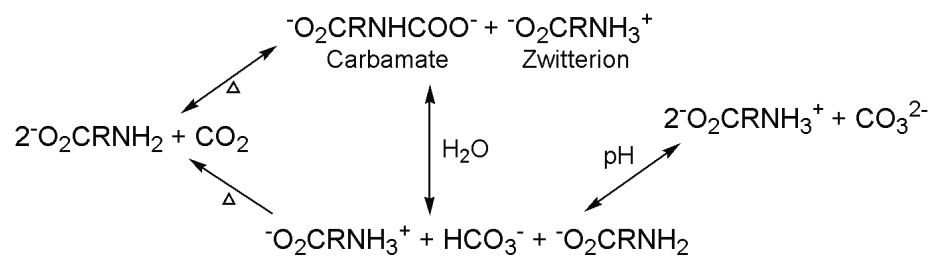

Figure 2.1: Reaction scheme for $\mathrm{CO}_{2}$ absorption in aqueous amino acid salt solution (Hook, 1997)

\subsection{Experimental section}

The $\mathrm{CO}_{2}$ [124-38-9] and $\mathrm{N}_{2}$ [7727-37-9] gases used were obtained from Linde Gas. The chemicals used were DL-methionine $(( \pm)$-2-amino-4-(methylmercapto)butyric acid, $\geq$ 99.0\%) [59-51-8], 6-aminohexanoic acid ( $\varepsilon$-aminocaproic acid, $\mathrm{H}_{2} \mathrm{~N}\left(\mathrm{CH}_{2}\right)_{5} \mathrm{CO}_{2} \mathrm{H}, \geq 99.0 \%$ ) [6o-32-2], $\beta$-alanine (3-aminopropionic acid, $\geq 98 \%$ ) [107-95-9], sarcosine (N-methylglycine, $\geq 98 \%$ ) [107-97-1], L-proline ( $(S)$-pyrrolidine-2-carboxylic acid, $\geq 98.5 \%$ ) [147-85-3], taurine (2-aminoethanesulfoni acid, $\geq 98 \%$ ) [107-35-7], MEA (2-aminoethanol, $\mathrm{C}_{2} \mathrm{H}_{7} \mathrm{NO}, \geq 99.0 \%$ ) [141-43-5], $\mathrm{KOH} \mathrm{(} \geq 85.0 \%$; water contents determined by titration) [1310-58-3], $\mathrm{NaOH}$ $(\geq 98 \%)$ [1310-73-2] and $\mathrm{LiOH}(\geq 98 \%)$ [1310-65-2]. The calibration compounds in the NMR studies were $\mathrm{KHCO}_{3}\left(99.7 \%\right.$ ) [298-14-6] and $\mathrm{K}_{2} \mathrm{CO}_{3}$ (99.0\%) [584-08-7]. All chemicals were purchased from Sigma-Aldrich and were utilized without further purification. Deuterium oxide $\left(\mathrm{D}_{2} \mathrm{O}\right)$ [7789-20-o] was used as NMR solvent (Merck).

Aqueous solution of amino acid salt was prepared by neutralizing an amino acid dissolved in deionized, double-distilled water with an equimolar quantity of an alkaline hydroxide. The actual concentration of solution was determined potentiometrically by titrating with a standard $1.000 \mathrm{~mol} \cdot \mathrm{dm}^{-3} \mathrm{HCl}$ solution [7647-01-o].

Saturation concentration of aqueous amino acid salt solution was determined by dissolving in deionized, distilled water an excess of equimolar quantities of an amino acid and an alkaline hydroxide, subsequently filtrating the solution to remove the solid phase and titrating the filtrated solution with a standard $\mathrm{HCl}$ solution. The density of the saturated solution was measured using a $10 \mathrm{~mL}$ Gay-Lussac pycnometer. The experimental method used was in accordance with the ASTM D3505 standard test method. The viscosity was measured using Ubbelohde-type viscometers according to the ASTM D445 standard test 
method. The experiments were performed at $293 \mathrm{~K}$ using a water bath (Tamson) with temperature controlled within $\pm 0.1 \mathrm{~K}$. The calibration runs using pure degassed, deionized water were also carried out and compared with the literature data (Al-Ghawas et al., 1989).

Window of operation for amino acid salts was investigated using the experimental set-up shown in Figure 2.2. The apparatus was designed to operate with both a pure $\mathrm{CO}_{2}$ gas stream at atmospheric pressure and for operation at $\mathrm{CO}_{2}$ partial pressures relevant to flue gas conditions. It consisted of thirty glass test tubes, a bubble column-type saturator, Sick Maihak IR $\mathrm{CO}_{2}$ analyzer, two water baths (Tamson, model T1ooo), two PTioo temperature sensors and mass flow controllers for pure $\mathrm{N}_{2}$ and $\mathrm{CO}_{2}$ gas streams (Brooks, model 5850 TR). The data acquisition system used LabView. The test tubes with absorbents were immersed in the water bath which temperature was regulated to within $\pm 0.1 \mathrm{~K}$. The saturator temperature was regulated by the second water bath which was operating at a slightly higher temperature than the actual absorption temperature. This temperature was chosen such that evaporation losses for distilled water in a single test tube were negligible (less than $0.15 \%$ per hour). First, the $\mathrm{CO}_{2}$ concentration in the feed gas was determined by bypassing the set of test tubes. A continuous diluted $\mathrm{CO}_{2}$ gas stream of known composition was prepared by mixing desired flow rates of pure $\mathrm{CO}_{2}$ and $\mathrm{N}_{2}$ using the mass flow controllers. After that, the feed gas was led to the water saturator and subsequently via the distributor to the thirty test tubes (arranged in parallel), each filled with an amino acid salt solution of different concentration and/or composition. Next, each outlet tube was connected to the collector and subsequently to the IR detector to measure the (collective) outlet concentration. The experiment was stopped when $\mathrm{CO}_{2}$ concentration in the inlet and outlet gas streams were the same. The samples were visually inspected for the crystals formation just after the experiment termination and after staying overnight in the water bath.

Aqueous amino acid salt solutions were flushed with pure $\mathrm{CO}_{2}$ to obtain the precipitate, which was then separated, washed and dried. The solid phase formation can be observed only under certain operational conditions, which differ for varying amino acids (salts). The absorption temperature and $\mathrm{CO}_{2}$ pressure were fixed at $293 \mathrm{~K}$ and $101 \mathrm{kPa}$, respectively.

Carbon, hydrogen and nitrogen contents were determined by $\mathrm{CHN}$ elemental analysis on an Interscience EA 200o. All NMR data were collected on a Bruker Avance $600 \mathrm{MHz}$ spectrometer using an inverse-detection triple nuclei probe, or a broad-band direct detection probe. The ${ }^{13} \mathrm{C}$ NMR data were obtained at $150.917 \mathrm{MHz}$ using an inverse-gated decoupling pulse sequence in order to minimize the coupling patterns. For the molecular composition determination, the ratio between the quaternary carbon signals was used. 
Absorption-desorption capacity of amino acid salt solution was investigated using the experimental method described by Yan et al. (2009). Pure $\mathrm{CO}_{2}$ gas was introduced to a solvent at $298 \mathrm{~K}$ to form the $\mathrm{CO}_{2}$ rich solution. The desorption behaviour of amino acid salt was studied in the apparatus shown in Figure 2.3. In the regeneration experiment, the rich solution in a Pyrex flask was heated to $373 \mathrm{~K}$ at atmospheric pressure. The water vapour was condensed by the efficient Pyrex condenser tube. The $\mathrm{CO}_{2}$ liquid loading in the rich/lean samples was determined using the analytical method described in detail by Blauwhoff et al. (1982).

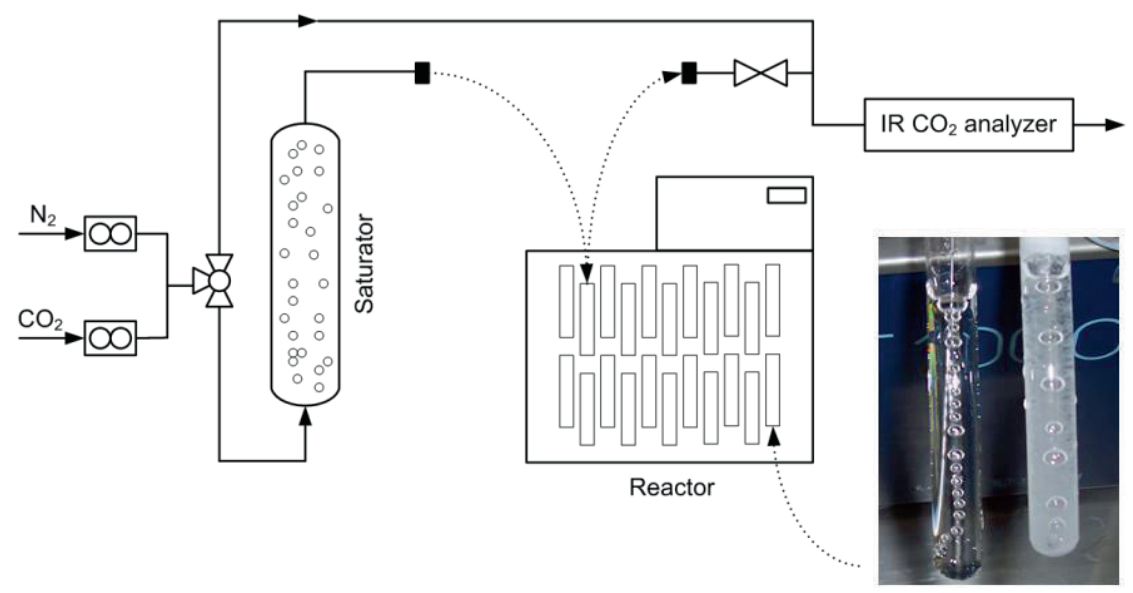

Figure 2.2. Screening apparatus for precipitation during $\mathrm{CO}_{2}$ capture

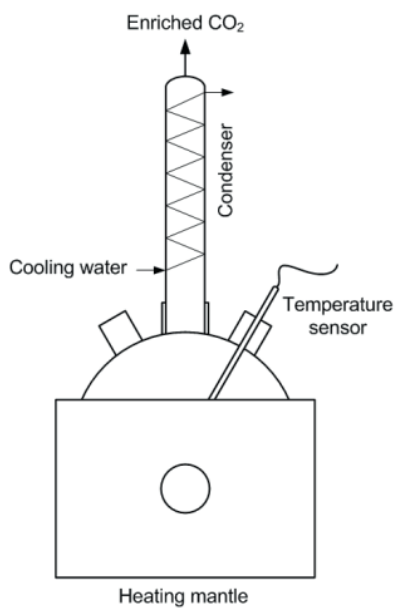

Figure 2.3: Experimental set-up for direct heating regeneration 


\subsection{Results and discussion}

In this section an overview of the results obtained for the most important performance parameters will be presented.

\subsubsection{Precipitation in $\mathrm{CO}_{2}-\mathrm{AAS}-\mathrm{H}_{2} \mathrm{O}$ absorption systems}

Precipitating $\mathrm{CO}_{2}$ solvents are gaining interest. In recent years especially the socalled Chilled-Ammonia process claimed to provide a more energy-efficient route for $\mathrm{CO}_{2}$ separation from flue gas, due to the precipitating behaviour. The use of ammonia as $\mathrm{CO}_{2}$ solvent is, however, not undisputed for safety and environmental reasons. Amino acid salt solutions may provide an environmentally benign solution here. An interesting feature of amino acid salts is their ability to form precipitates when absorbing $\mathrm{CO}_{2}$.

When investigating the operational conditions at which the amino acid salt-based $\mathrm{CO}_{2}$ absorption systems tend to precipitate, it is required to know the saturation concentration (maximum solubility) of these chemical solvents. While the solubility of amino acids in water has been well documented (Cabani and Gianni, 1986; Hutchens, 1976; Yalkowsky and He, 2003), no experimental data were found for alkaline salts of these compounds and was therefore determined in the present work. Along with the maximum solubility, the corresponding density and viscosity of solutions were measured at $293 \mathrm{~K}$, and the results are reported in Table A.1 in the Appendix.

The tendency of amino acid salts to form solid products under varying operational conditions of $\mathrm{CO}_{2}$ absorption process was investigated using the experimental set-up presented in Figure 2.2. Prior to the absorption experiments, water evaporation tests (using test tubes filled with water) were performed at both temperatures used in the experiments in order to fine-tune the gas saturator temperature. After this, it was found that changes in the solvent composition due to the evaporation losses are negligible. Subsequently, the absorption experiments were performed at 293 and $313 \mathrm{~K}$, for $\mathrm{CO}_{2}$ partial pressures relevant to flue gas conditions and at atmospheric pressure (101 kPa). The concentration of amino acid salt was varied up to and beyond the saturation concentration. Figures 2.4 and 2.5 illustrate the window of operation for potassium salts of taurine, sarcosine, $\beta$-alanine, L-proline and 6-aminohexanoic acid, respectively. These data are given also in Table A.2 in the Appendix. In the figures, only the results for the concentrations most close to the "precipitation boundary" are reported. The open symbols indicate the experimental conditions without the precipitate formation and the closed ones indicate precipitation during the absorption process. The width of a transition zone was imposed by limitations of 
the experimental method used. In this region, precipitation can still take place but it was not possible to verify this experimentally. Kumar et al. (2003b) reported the precipitate formation when absorbing the diluted $\mathrm{CO}_{2}$ gas streams $\left(\mathrm{CO}_{2}\right.$ partial pressure up to $\left.6 \mathrm{kPa}\right)$ in potassium salts of taurine $\left(C_{m}=0.5-4 \mathrm{M}\right)$ at 298 and $313 \mathrm{~K}$. Their data are included in Figure 2.4. A good agreement between the experimental and literature data can be observed. For potassium DL-methioninate, the solid product precipitates already from $0.3 \mathrm{~mol} \cdot \mathrm{dm}^{-3}$ amino acid salt solutions at $293 \mathrm{~K}$ and for $\mathrm{CO}_{2}$ partial pressure of $10.82 \mathrm{kPa}$. In general, it can be observed that the boundary between non-precipitating and precipitating system strongly depends on the amino acid salt concentration, absorption temperature and $\mathrm{CO}_{2}$ partial pressure. At constant temperature, the boundary shifts to lower $\mathrm{CO}_{2}$ partial pressure with increasing amino acid salt concentration. Alternatively, at constant $\mathrm{CO}_{2}$ partial pressure, the boundary shifts to higher amino acid salt concentration with increasing temperature. This system behaviour can be explained by an influence of absorption temperature and chemical speciation in the liquid phase on the solubility products of the solids formed (Needham et al., 1971; Pradhan and Vera, 1998).
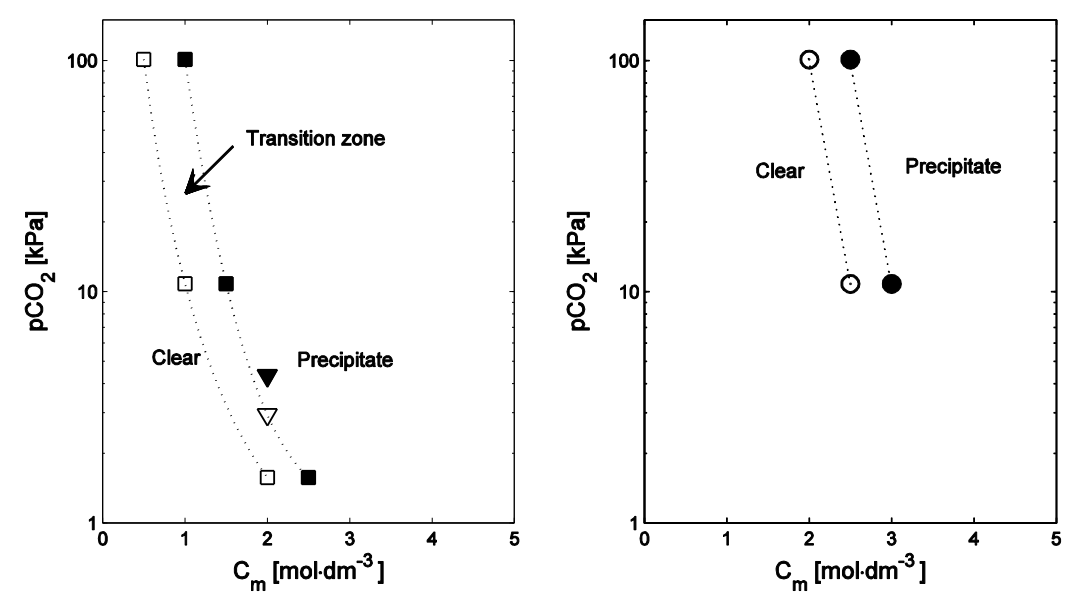

Figure 2.4: Window of operation for precipitation in potassium salts of taurine. This work: $\square$, $T=293 \mathrm{~K} ; \mathrm{O}, T=313 \mathrm{~K} ; \nabla, T=298 \mathrm{~K}$ Kumar et al. (2003b). Open symbols for non-precipitating systems and closed symbols for precipitation 

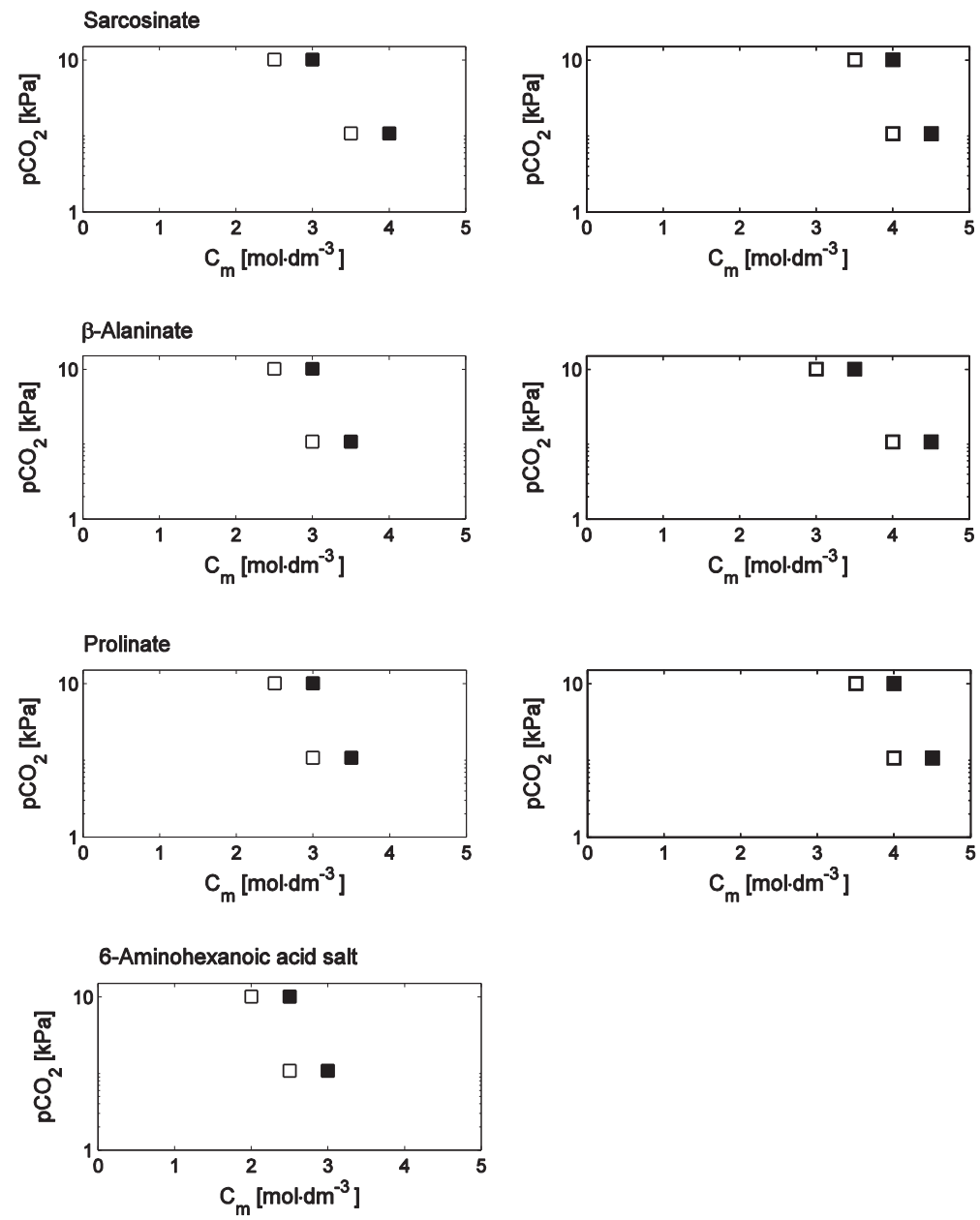

Figure 2.5: Window of operation for precipitation in potassium salts of sarcosine, $\beta$-alanine, L-proline and 6-aminohexanoic acid. $\square, T=293 \mathrm{~K}$ (left); $\square, T=313 \mathrm{~K}$ (right). Open symbols for non-precipitating systems and closed symbols for precipitation

The physical and chemical character of the precipitates and slurries formed as a result of $\mathrm{CO}_{2}$ absorption in aqueous solutions of potassium salts of taurine, DL-methionine, L-proline, sarcosine, $\beta$-alanine and 6-aminohexanoic acid is revealed. Table 2.1 presents the results from elemental $\mathrm{CHN}$ analysis of the precipitates obtained from these solvents. In the table, the theoretical composition of taurine, DL-methionine and potassium bicarbonate has been included. On the basis of the percentages by weight of the elements, it is conducted that for potassium salts of taurine and DL-methionine the solid product formed is the amino acid itself. For potassium DL-methioninate this result is consistent with Kumełan et al. (2010). 
Kumar et al. (2003b) reported the solid formation during $\mathrm{CO}_{2}$ absorption in aqueous solutions of potassium taurate. With the use of ${ }^{13} \mathrm{C}$ NMR they identified the precipitate to be taurine in the zwitterionic form, which is consistent with the present data. Only minor amounts of nitrogen were present in the solids formed from potassium salts of sarcosine, L-proline, $\beta$-alanine and 6-aminohexanoic acid - see Table 2.1. Percentages by weight of carbon and hydrogen in these precipitates agreed well with the theoretical composition of potassium bicarbonate.

Table 2.1: CHN analysis of the precipitates obtained from potassium salts of amino acids

\begin{tabular}{|c|c|c|c|c|c|c|c|}
\hline \multirow[t]{2}{*}{ Solvent } & \multirow[t]{2}{*}{ Precipitate } & \multicolumn{2}{|c|}{$\begin{array}{c}\mathrm{C} \\
{[\mathrm{wt} \%]}\end{array}$} & \multicolumn{2}{|c|}{$\begin{array}{c}\mathrm{H} \\
{[\mathrm{wt} \%]}\end{array}$} & \multicolumn{2}{|c|}{$\begin{array}{c}\mathrm{N} \\
{[\mathrm{wt} \%]}\end{array}$} \\
\hline & & $\mathrm{T}$ & Meas. & $\mathrm{T}$ & Meas. & $\mathrm{T}$ & Meas. \\
\hline Taurate & Amino acid & 19.20 & 19.60 & 5.64 & 5.45 & 11.19 & 10.64 \\
\hline DL-Methioninate & Amino acid & 40.25 & 41.03 & $7 \cdot 43$ & $7 \cdot 48$ & $9 \cdot 39$ & 9.13 \\
\hline Sarcosinate & Bicarbonate & 12.00 & 11.87 & 1.01 & 1.09 & 0.00 & 0.27 \\
\hline L-Prolinate & Bicarbonate & 12.00 & 11.84 & 1.01 & 1.01 & 0.00 & 0.07 \\
\hline$\beta$-Alaninate & Bicarbonate & 12.00 & 12.01 & 1.01 & 1.14 & 0.00 & 0.20 \\
\hline $\begin{array}{r}\text { 6-Aminohexanoic } \\
\text { acid salt }\end{array}$ & Bicarbonate & 12.00 & 12.61 & 1.01 & 1.28 & 0.00 & 0.28 \\
\hline
\end{tabular}

T= Theoretical; Meas. $=$ Measured

In order to understand the influence of the counterion (cation) on the solid composition, additional $\mathrm{CO}_{2}$ absorption experiments using aqueous sodium and lithium salts of the considered amino acids were carried out. Details of the analysis of the precipitates formed can be found in the Appendix. In Table $\mathbf{2 . 2}$ the results for the precipitates from potassium, sodium and lithium salts are listed. Generally, it was observed that the solid phase can be precipitated from the system as amino acid, bicarbonate or bicarbonate salt of amino acid (salt). The chemical character of the solids can remain the same for different counterions of the amino acid salt or it can change with the solvent composition as in the case of 6-aminohexanoic acid. It appears also that amino acids with higher base strength values (see Table 2.3) have stronger tendency to precipitate the $\mathrm{CO}_{2}$ species; which might be related to the fact that at the solution $\mathrm{pH}$ higher than 10 the direct reaction of dissolved $\mathrm{CO}_{2}$ to form bicarbonate ions plays an important role in absorption process (Kohl and Nielsen, 1997).

Figure 2.6 presents several typical (physical) appearances of the obtained slurries, as observed in the investigated three-phase $\mathrm{CO}_{2}$ absorption systems. Despite of clear differences in the physical character and crystal morphology of individual suspensions, most of the solids were easily re-suspendable with a negligible tendency to adhere to the reactor wall. This is potentially important from the absorber operation and slurry handling point of 
view. An exception from this behaviour is shown by solids crystallized from alkaline salts of DL-methionine, which formed 'sponge/cake-a-like' structures. These slurries were characterized by a significant amount of not suspendable solid products that adhered to the inside wall of the reactor during the experiments. On the commercial scale, a similar behaviour accompanied by a scale formation in the absorption column could be encountered, for example, in the flue gas desulfurization systems (FGD) for the calcium sulphate (gypsum) slurries (Ellis et al., 200o). Very low concentrations of DL-methioninate solutions would have to be used in order to remain in the non-precipitating regime of operation. This amino acid was therefore excluded from the vapour-liquid equilibrium screening experiments.

Table 2.2: Chemical composition of the precipitates from potassium, sodium and lithium salts of amino acids

\begin{tabular}{rlcl}
\hline & Potassium & Sodium & Lithium \\
\cline { 2 - 4 } Solvent & & Precipitate & \\
\hline Taurate & Amino acid & Amino acid & Amino acid \\
DL-Methioninate & Amino acid & Amino acid & Amino acid \\
Sarcosinate & Bicarbonate & Bicarbonate & \\
L-Prolinate & Bicarbonate & Bicarbonate & \\
6-Aminohexanoic acid salt & Bicarbonate & Bicarbonate salt of & \\
& & amino acid salt & \\
$\beta$-Alaninate & Bicarbonate & & \\
\hline
\end{tabular}
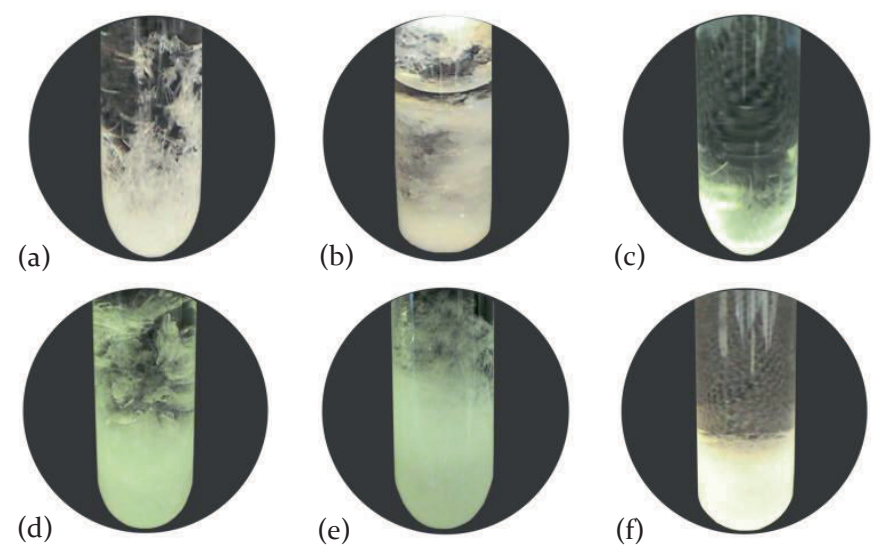

Figure 2.6: Slurries formed as a result of $\mathrm{CO}_{2}$ absorption in aqueous potassium salts of the following amino acids: (a) taurine, (b) DL-methionine, (c) L-proline, (d) $\beta$-alanine, (e) sarcosine, (f) 6-aminohexanoic acid 


\subsubsection{Absorption kinetics}

Van Holst et al. (2009) screened several potassium salts of amino acids with respect to their $\mathrm{CO}_{2}$ absorption reaction kinetics. Among the investigated amino acids were taurine, DL-methionine, L-glutamic acid, sarcosine, $\beta$-alanine, L-proline, 6-aminohexanoic acid and L-arginine. The absorption experiments were carried out at temperature of $298 \mathrm{~K}$ using $0.5 \mathrm{~mol} \cdot \mathrm{dm}^{-3}$ aqueous solutions in a stirred cell. In their article, a Brønsted plot, where the overall rate constant, $k_{o v}$, is plotted against the $\mathrm{p} K_{a}$ value, was presented. In this figure, they also included the literature $k_{o v}$ values for glycine, MEA and DEA. These data are reported here as Table 2.3. Generally, a high reaction rate is important to reduce the size and hence the capital costs of an absorber, while a low $\mathrm{p} K_{a}$ is of importance to minimize the energy requirement in a desorber (Kohl and Nielsen, 1997). Based on these criteria, salts of L-proline, sarcosine and glycine, which combine a relatively high reaction rate constant with a relatively low $\mathrm{p} K_{a}$ value, were identified by the authors as the most promising solvents for $\mathrm{CO}_{2}$ capture. Furthermore and unlike for (alkanol)amines (Versteeg et al., 1989), no close relation between the $\mathrm{p} K_{a}$ and $k_{\text {ov }}$ parameters was found for the amino acid salts studied.

Table 2.3: $k_{o v}$ vs. $K_{a}$ values for potassium salts of amino acids, MEA and DEA (van Holst et al., 2009)

\begin{tabular}{rcc}
\hline Solvent & $\begin{array}{c}k_{o v}^{*} \\
{\left[\mathrm{~s}^{-1}\right]}\end{array}$ & $\begin{array}{c}\mathrm{p} K_{a} \\
{[-]}\end{array}$ \\
\hline Taurate & 1276 & 9.06 \\
DL-Methioninate & 812 & 9.20 \\
L-Glutamic acid salt & 1442 & 9.98 \\
Sarcosinate & 2973 & 10.21 \\
$\beta$-Alaninate & 1499 & 10.33 \\
L-Prolinate & 7218 & 10.64 \\
6-Aminohexanoic acid salt & 1266 & 10.95 \\
L-Argininate & 4203 & 12.48 \\
Glycinate & 4000 & 9.78 \\
Monoethanolamine & 2500 & 9.62 \\
Diethanolamine & 215 & 8.88 \\
\hline
\end{tabular}

${ }^{*}$ Normalized at $0.5 \mathrm{~mol} \cdot \mathrm{dm}^{-3}$

\subsubsection{Absorption capacity and regeneration screening}

Another important parameter in chemical absorption of $\mathrm{CO}_{2}$ is a cyclic capacity of a solvent, $\Delta \alpha$. This cyclic, or 'working', capacity is defined as a difference in rich and lean $\mathrm{CO}_{2}$ loading and this determines to a large extent the required solvent circulation rate. 
Hook (1997) measured the $\mathrm{CO}_{2}$ capacity of $2.5 \mathrm{~mol} \cdot \mathrm{dm}^{-3}$ aqueous solutions of MEA, potassium salts of glycine and several sterically hindered amino acids at 295 and $373 \mathrm{~K}$ using pure $\mathrm{CO}_{2}$ and $\mathrm{CO}_{2}$ /air gas streams at pressure of $101 \mathrm{kPa}$. For absorption of a pure $\mathrm{CO}_{2}$ gas stream, the $\mathrm{CO}_{2}$ loading for MEA and potassium glycinate was 0.76 and 0.78 (mole $\mathrm{CO}_{2}$ per mole solvent), respectively. The lean $\mathrm{CO}_{2}$ loading for MEA and potassium glycinate as obtained by boiling the $\mathrm{CO}_{2}$ saturated solutions was found to be 0.18 and 0.36 (mole $\mathrm{CO}_{2}$ per mole solvent), respectively, and hence, a $38 \%$ smaller cyclic capacity for potassium glycinate as compared to MEA was found. In the present work, the $\mathrm{CO}_{2}$ loading in $1 \mathrm{~mol} \cdot \mathrm{dm}^{-3}$ aqueous solutions of MEA and potassium salts of taurine, sarcosine, L-proline, $\beta$-alanine and 6-aminohexanoic acid was determined at 298 and at $373 \mathrm{~K}$, and pressure of 101 $\mathrm{kPa}$ (as a screening method for the lean loading upon solvent regeneration). The results for this absorption capacity at 298 and $373 \mathrm{~K}$ are given in Table 2.4. In addition, several tests were performed for potassium salt of DL-methionine. Due to precipitation problems occurring in the system even at relatively low solution concentrations (well below $0.25 \mathrm{M}$ ), DL-methioninate was essentially excluded from this part of the screening work. A difference in the $\Delta \alpha$ values for the considered compounds is rather small; taking also into account the experimental error of a few percent. Nevertheless, some trends are visible. Of the considered systems, the lowest $\mathrm{CO}_{2}$ cyclic ability can be observed for MEA and taurine, whereas the highest absolute $\mathrm{CO}_{2}$ uptake is found for $\beta$-alanine; which means that also (bi)carbonates are formed. For this compound, the increased $\mathrm{CO}_{2}$ cyclic capacity is accompanied, however, by an overall reduction in the absorption rate as contrary to, for example, sarcosine and L-proline. Potassium salts of sarcosine, L-proline and 6-aminohexanoic acid show comparable behaviour in $\mathrm{CO}_{2}$ absorption and desorption.

Table 2.4: $\mathrm{CO}_{2}$ capacity (in mole $\mathrm{CO}_{2}$ per mole solvent) of $1 \mathrm{M}$ solutions of potassium salts of amino acids and MEA at $298 \mathrm{~K}$ and $373 \mathrm{~K}$

\begin{tabular}{rccc}
\hline Solvent & $\alpha_{\text {rich }}$ & $\alpha_{\text {lean }}$ & $\Delta \alpha$ \\
\hline Taurate & 0.80 & 0.14 & 0.66 \\
Sarcosinate & 0.93 & 0.23 & 0.70 \\
$\beta$-Alaninate & 0.96 & 0.24 & 0.72 \\
L-Prolinate & 0.91 & 0.22 & 0.69 \\
6-Aminohexanoic acid salt & 0.92 & 0.22 & 0.70 \\
Monoethanolamine & 0.87 & 0.25 & 0.62 \\
\hline
\end{tabular}

In literature, some attempt has been made to correlate the base strength with the $\mathrm{CO}_{2}$ absorption capacity of (alkanol)amines (Mergler et al., 2011; Puxty et al., 2009; da Silva, 2011). Puxty et al. (2009) measured absorption of $\mathrm{CO}_{2}$ at $313 \mathrm{~K}$ for 76 amines. The absorption capacity of all amines was plotted as a function of $\mathrm{p} K_{a}$. Generally, no relation in the absorption behaviour with $\mathrm{p} K_{a}$ for all studied compounds was observed. It was concluded 
that primary and secondary amines do not show a strong relation with $\mathrm{p} K_{a}$ at absorber conditions. Apparently, the sensitivity of the carbamate formation to $\mathrm{pH}$, and thus to $\mathrm{p} K_{a}$, is dependent on the carbamate stability constant, which varies among amines and does not seem to be related to the same molecular configuration affecting $\mathrm{p} K_{a}$. For tertiary amines, a strong relation with $\mathrm{p} K_{a}$ was found, as this is related to the bicarbonate formation being the dominant reaction pathway for $\mathrm{CO}_{2}$ absorption. The $\mathrm{CO}_{2}$ hydration reaction is independent of the amine but (due to the small stability constant for the bicarbonate formation) shows strong $\mathrm{pH}$ dependence. Also in the present work, only a weak relation in the absorption behaviour with $\mathrm{p} K_{a}$ was found for the tested amino acids.

\subsection{Conclusions}

Some general observations were made for physical and chemical character of the slurries formed during $\mathrm{CO}_{2}$ absorption in aqueous alkaline salts of amino acids, which can be useful when designing the $\mathrm{CO}_{2}-\mathrm{AAS}-\mathrm{H}_{2} \mathrm{O}$ process. For most of the considered systems (except for DL-methionine) a relatively broad window of operation without the solid formation was observed. For taurine and DL-methionine, due to the limited zwitterion solubility in the $\mathrm{CO}_{2}$-saturated amino acid salt solution, the precipitate was the amino acid itself. In the other systems, the precipitate contained the $\mathrm{CO}_{2}$ species, most often as a bicarbonate salt. Different chemical compositions of the precipitate formed will probably affect absorption capacities and regeneration conditions and hence process development. All tested amino acids had comparable cyclic capacities to the industry standard MEA but only L-proline and sarcosine showed also higher reactivity towards $\mathrm{CO}_{2}$. Based on the results of this study, the (alkaline salt of) imino acid L-proline was chosen for further investigation in this thesis. 


\section{Appendix}

\section{A.1 Operating window and physical properties}

Table A.1 reports the maximum solubility and the corresponding density and viscosity of potassium salts of taurine, sarcosine, $\beta$-alanine, L-proline, DL-methionine and 6-aminohexanoic acid at $293 \mathrm{~K}$ as determined in the present work. Table A.2 reports the window of operation for potassium salts of the considered amino acids. In the table, only the results for concentrations most close to the precipitation boundary are given. In the last column of this table the number of phases $(\mathrm{Np})$ is reported, which is equal to two for the non-precipitating gas-liquid system and three for the precipitating one.

Table A.1: Saturation concentration and the corresponding density and viscosity of potassium salts of amino acids at $293 \mathrm{~K}$

\begin{tabular}{rccc}
\hline Solvent & $\begin{array}{c}S_{\max } \\
{\left[\mathrm{mol} \cdot \mathrm{dm}^{-3}\right]}\end{array}$ & $\begin{array}{c}\rho \\
{\left[\mathrm{g} \cdot \mathrm{cm}^{-3}\right]}\end{array}$ & $\begin{array}{c}\mu \\
{\left[\mathrm{mPa} \cdot \mathrm{s}^{-1}\right]}\end{array}$ \\
\hline $\mathrm{H}_{2} \mathrm{O}$ (this work) & & 0.9982 & 1.007 \\
$\mathrm{H}_{2} \mathrm{O}$ (Al-Ghawas et al., 1989) & & 0.9982 & 1.014 \\
Taurate & 6.56 & 1.4688 & 34.771 \\
Sarcosinate & 6.98 & 1.3147 & 44.337 \\
$\beta$-Alaninate & 7.50 & 1.3767 & 122.432 \\
L-Prolinate & 5.56 & 1.2927 & 44.337 \\
DL-Methioninate & 2.81 & 1.1832 & 5.596 \\
6-Aminohexanoic acid salt & 3.46 & 1.1596 & 12.260 \\
\hline
\end{tabular}


Table A.2: Window of operation for precipitation in potassium salts of amino acids

\begin{tabular}{|c|c|c|c|c|}
\hline Solvent & $\begin{array}{c}T \\
{[\mathrm{~K}]}\end{array}$ & $\begin{array}{l}p_{\mathrm{CO}_{2}} \\
{[\mathrm{kPa}]}\end{array}$ & $\begin{array}{c}C_{m} \\
{[\mathrm{M}]}\end{array}$ & $\mathrm{Np}$ \\
\hline \multirow[t]{10}{*}{ Taurate } & 293 & 1.57 & 2.0 & 2 \\
\hline & & 1.57 & 2.5 & 3 \\
\hline & & 10.82 & 1.0 & 2 \\
\hline & & 10.82 & 1.5 & 3 \\
\hline & & 101 & 0.5 & 2 \\
\hline & & 101 & 1.0 & 3 \\
\hline & 313 & 10.82 & 2.5 & 2 \\
\hline & & 10.82 & 3.0 & 3 \\
\hline & & 101 & 2.0 & 2 \\
\hline & & 101 & 2.5 & 3 \\
\hline \multirow[t]{8}{*}{ Sarcosinate } & 293 & 10.82 & 3.5 & 2 \\
\hline & & 10.82 & 4.0 & 3 \\
\hline & & 101 & 2.5 & 2 \\
\hline & & 101 & 3.0 & 3 \\
\hline & 313 & 10.82 & 4.0 & 2 \\
\hline & & 10.82 & $4 \cdot 5$ & 3 \\
\hline & & 101 & $3 \cdot 5$ & 2 \\
\hline & & 101 & 4.0 & 3 \\
\hline \multirow[t]{8}{*}{$\beta$-Alaninate } & 293 & 10.82 & 3.0 & 2 \\
\hline & & 10.82 & $3 \cdot 5$ & 3 \\
\hline & & 101 & 2.5 & 2 \\
\hline & & 101 & 3.0 & 3 \\
\hline & 313 & 10.82 & 4.0 & 2 \\
\hline & & 10.82 & 4.5 & 3 \\
\hline & & 101 & 3.0 & 2 \\
\hline & & 101 & $3 \cdot 5$ & 3 \\
\hline \multirow[t]{8}{*}{ L-Prolinate } & 293 & 10.82 & 3.0 & 2 \\
\hline & & 10.82 & $3 \cdot 5$ & 3 \\
\hline & & 101 & 2.5 & 2 \\
\hline & & 101 & 3.0 & 3 \\
\hline & 313 & 10.82 & 3.5 & 2 \\
\hline & & 10.82 & 4.0 & 3 \\
\hline & & 101 & 3.0 & 2 \\
\hline & & 101 & $3 \cdot 5$ & 3 \\
\hline \multirow[t]{4}{*}{ 6-Aminohexanoic acid salt } & 293 & 10.82 & 2.5 & 2 \\
\hline & & 10.82 & 3.0 & 3 \\
\hline & & 101 & 2.0 & 2 \\
\hline & & 101 & 2.5 & 3 \\
\hline \multirow[t]{2}{*}{ DL-Methioninate } & 293 & 10.82 & 0.1 & 2 \\
\hline & & 10.82 & 0.3 & 3 \\
\hline
\end{tabular}




\section{A.2 Identification of the solid phase}

The solid products precipitating upon a reactive absorption of $\mathrm{CO}_{2}$ in aqueous alkaline (sodium-, lithium-) salts of a series of amino acids were identified using the CHN elemental analysis and ${ }^{13} \mathrm{C}$ NMR. Among the investigated amino acids were taurine, DL-methionine, sarcosine, L-proline and 6-aminohexanoic acid.

Table A.3 presents the results from the $\mathrm{CHN}$ analysis of the solids precipitating from alkaline salts of taurine, DL-methionine, sarcosine and L-proline. In case of the solid product from sodium salt of 6-aminohexanoic acid, elemental analysis did not answer to what is precipitating and hence ${ }^{13} \mathrm{C}$ NMR was applied (see Figure A.1). Determination of carbon, nitrogen and hydrogen contents in the precipitates from sodium and lithium salts of taurine and DL-methionine has shown that it is the amino acid itself that precipitates. Different composition pattern could be observed for the solid products obtained from sodium salts of sarcosine and L-proline. Percentages by weight of carbon and hydrogen in these precipitates agreed well with the theoretical composition of bicarbonate, with only minor amounts of nitrogen present $(\% \mathrm{~N}<0.12)$.

Figure A.1 shows the ${ }^{13} \mathrm{C}$ NMR spectrum of the solids precipitating from sodium salt of 6-aminohexanoic acid. In the spectrum, the aliphatic peaks at 25.2, 25.4, 26.5, 37.2 and $39.3 \mathrm{ppm}$, combined with the aromatic signal at $183.6 \mathrm{ppm}$, and the bicarbonate signal at 161.3 ppm, corresponds to bicarbonate salt of amino acid salt in the precipitate. This assumption was made based the following observations:

- As the integral area of the carboxyl group signal was increased compared to the amino acid pattern, it was assumed that the amino acid species exist in the solids as the amino acid salt (Tian and Yin, 2004).

- The down-field signal at $161.3 \mathrm{ppm}$ was located in the region expected for the bicarbonate/carbonate ions in water. The limiting shifts in samples containing solely $\mathrm{HCO}_{3}^{-}$or $\mathrm{CO}_{3}^{2-}$ species were found at 160.4 and $168.3 \mathrm{ppm}$, respectively. It was therefore concluded that the analyzed signal belonged to the bicarbonate ion in the precipitate. The measured values agreed well with the literature data by Abbott et al. (1982).

- The 1 to 1 ratio between the two quaternary carbon atom signals was found.

The five remaining aliphatic signals (25.7, 26.0, 29.3, 37.6 and $41.2 \mathrm{ppm})$ and the carboxylic carbon atom signal at $184.1 \mathrm{ppm}$ corresponded to the amino acid (salt). The amount of the latter one was calculated to be around $12 \%$. 
Table A.3: CHN analysis of the precipitates obtained from sodium and lithium salts of amino acids

\begin{tabular}{|c|c|c|c|c|c|c|c|}
\hline \multirow[t]{2}{*}{ Solvent } & \multirow[t]{2}{*}{ Precipitate } & \multicolumn{2}{|c|}{$\begin{array}{c}\mathrm{C} \\
{[\mathrm{wt} \%]}\end{array}$} & \multicolumn{2}{|c|}{$\begin{array}{c}\mathrm{H} \\
{[\mathrm{wt} \%]}\end{array}$} & \multicolumn{2}{|c|}{$\begin{array}{c}\mathrm{N} \\
{[\mathrm{wt} \%]}\end{array}$} \\
\hline & & $\mathrm{T}$ & Meas. & $\mathrm{T}$ & Meas. & $\mathrm{T}$ & Meas. \\
\hline Sodium Taurate & Amino acid & 19.20 & 19.44 & 5.64 & $5 \cdot 36$ & 11.19 & 10.48 \\
\hline Lithium Taurate & Amino acid & 19.20 & 19.56 & 5.64 & 5.45 & 11.19 & 10.51 \\
\hline Sodium DL-Methioninate & Amino acid & 40.25 & 40.50 & $7 \cdot 43$ & 7.28 & $9 \cdot 39$ & 9.24 \\
\hline Lithium DL-Methioninate & Amino acid & 40.25 & 40.62 & $7 \cdot 43$ & $7 \cdot 77$ & $9 \cdot 39$ & 9.63 \\
\hline Sodium Sarcosinate & Bicarbonate & $14 \cdot 30$ & 14.28 & 1.20 & 1.28 & 0.00 & 0.12 \\
\hline Sodium L-Prolinate & Bicarbonate & $14 \cdot 30$ & 14.33 & 1.20 & 1.23 & 0.00 & 0.06 \\
\hline
\end{tabular}

T= Theoretical; Meas. = Measured

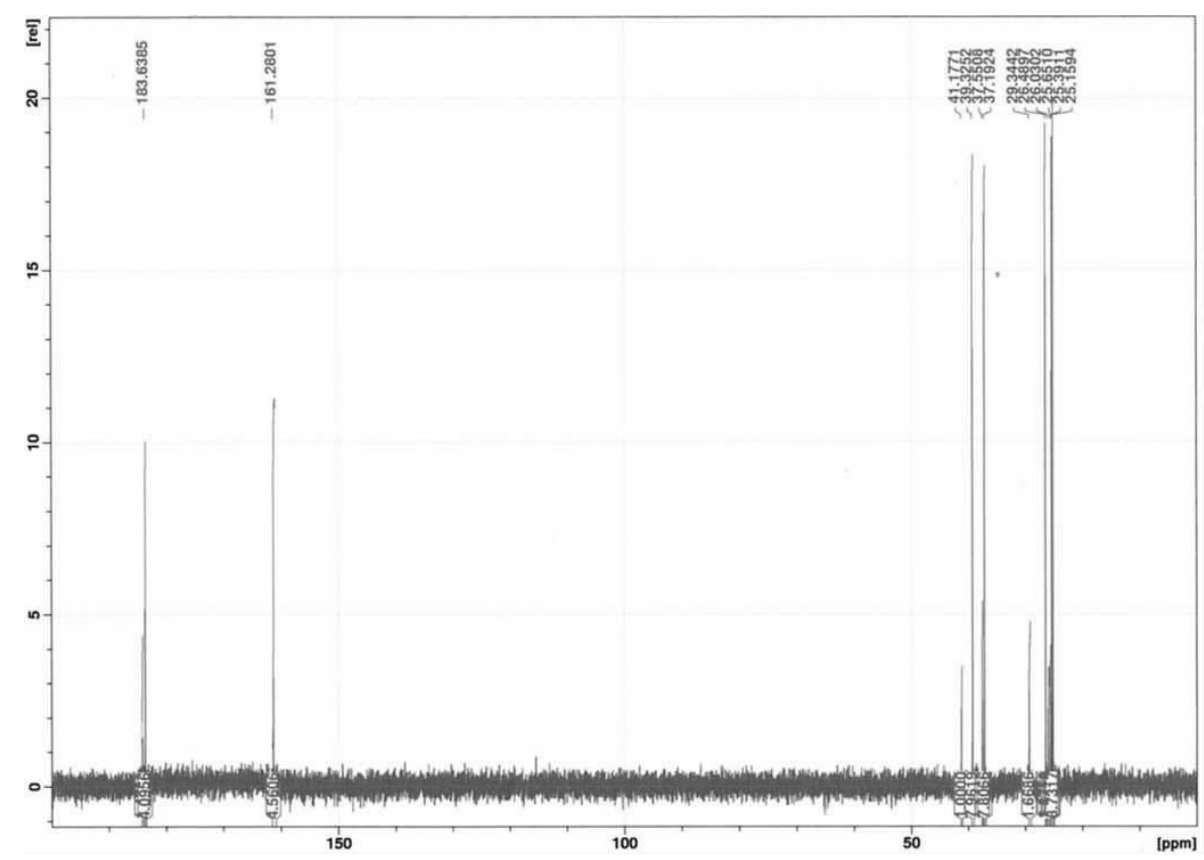

Figure A.1: ${ }^{13} \mathrm{C}$ NMR spectrum of the precipitate formed with sodium salt of 6-aminohexanoic acid 


\section{Bibliography}

Abbott, T.M., Buchanan, G.W., Kruus, P., Lee, K.C., 1982. ${ }^{13} \mathrm{C}$ nuclear magnetic resonance and Raman investigations of aqueous carbon dioxide systems. Canadian Journal of Chemistry 6o, 100o1006

Al-Ghawas, H.A., Hagewiesche, D.P., Ruiz-Ibanez, G., Sandall, O.C., 1989. Physicochemical properties important for carbon dioxide absorption in aqueous methyldiethanolamine. Journal of Chemical and Engineering Data 34, 385-391

Annual Book of ASTM Standards, 1984, Philadelphia PA

Blauwhoff, P.M.M., 1982. Selective absorption of hydrogen sulphide from sour gases by alkanolamine solutions. Ph.D. Thesis, University of Twente, The Netherlands

Cabani, S., Gianni, P., 1986. In: Thermodynamic Data for Biochemistry and Biotechnology, Hinz, H.J. ed., Springer-Verlag

EC, 2008. Communication from the Commission to the European Parliament, The Council, The European Economic and Social Committee and The Committee of the Regions - 2020 by 2020 Europe's climate change opportunity. E. Commission, Commission of the European Communities

Feron, P.H.M., ten Asbroek, N., 2005. New solvents based on amino acid salts for $\mathrm{CO}_{2}$ from flue gases. GHGT-7, Vancouver, Canada

Goff, G.S., Rochelle, G.T., 2006. Oxidation inhibitors for copper and iron catalyzed degradation of monoethanolamine in $\mathrm{CO}_{2}$ capture processes. Industrial and Engineering Chemistry Research 45, $2513-2521$

Van Holst, J., Kersten, S.R.A., Hogendoorn, K.J.A., 20o8. Physiochemical properties of several aqueous potassium amino acid salts. Journal of Chemical and Engineering Data 53, 1286-1291

Van Holst, J., Versteeg, G.F., Brilman, D.W.F., Hogendoorn, J.A., 20o9. Kinetic study of $\mathrm{CO}_{2}$ with various amino acid salts in aqueous solution. Chemical Engineering Science 64, 59-68

Hook, R.J., 1997. An investigation of some sterically hindered amines as potential carbon dioxide scrubbing compounds. Industrial and Engineering Chemistry Research 36, 1779-179o

Hutchens, J.O., 1976. In: Handbook of Biochemistry and Molecular Biology, Physical and Chemical data, Fasman, G.D. ed., CRC Press Inc

Idem, R., Tontiwachwuthikul, P., 2006. Preface for the special issue on the capture of carbon dioxide from industrial sources: technological developments and future opportunities. Industrial and Engineering Chemistry Research 45, 2413

Kohl, A.L., Nielsen, R.B., 1997. Gas Purification: $5^{\text {th }}$ Edition. Gulf Publishing Company, Houston 
Kumar, P.S., Hogendoorn, J.A., Feron, P.H., Versteeg, G.F., 2003a. Kinetics of the reaction of $\mathrm{CO}_{2}$ with aqueous potassium salt of taurine and glycine. American Institute of Chemical Engineers Journal 49, 203-213

Kumar, P.S., Hogendoorn, J.A., Timmer, J.S. Feron, P.H.M., 2003b. Equilibrium solubility of $\mathrm{CO}_{2}$ in aqueous potassium taurate solutions: part 2. Experimental VLE data and model. Industrial and Engineering Chemistry Research 42, 2841-2852

Kumełan J., Pérez-Salado, Á., Maurer, G., 2010. Solubility of $\mathrm{CO}_{2}$ in aqueous solutions of methionine and in aqueous solutions of $\left(\mathrm{K}_{2} \mathrm{CO}_{3}\right.$ and methionine). Industrial Engineering and Chemistry Research 49, 3910-3918

Mergler, Y., Rumley-van Gurp, R., Brasser, P., de Koning, M. Goetheer, E., 2011. Solvents for $\mathrm{CO}_{2}$ capture. Structure-activity relationships combined with vapor-liquid equilibrium measurements. Energy Procedia 4, 259-266

Needham, T.E., Paruta, A.N., Gerraughty, R.J., 1971. Solubility of amino acids in pure solvent systems. Journal of pharmaceutical sciences 6o, 565-567

Pradhan, A.A., Vera, J.H., 1998. Effect of acids and bases on the solubility of amino acids. Fluid Phase Equilibria 152, 121-132

Puxty, G., Rowland, R., Allport, A., Yang, Q., Bown, M., Burns, R., Maeder, M., Attalla, M., 2009. Carbon dioxide post-combustion capture: a novel screening study of the carbon dioxide absorption performance of 76 amines. Environmental Science and Technology 43, 6427-6433

Portugal, A.F., Souse, J.M., Magalhães, F.D., Mendes, A., 2009. Solubility of carbon dioxide in aqueous solutions of amino acid salts. Chemical Engineering Science 64, 1993-2002

Da Silva, E.F., 2011. Theoretical study of the equilibrium constants for solvents for $\mathrm{CO}_{2}$ capture, Energy Procedia 4, 164-170

Supap, T., Idem, R., Tontiwachwuthikul, P., Saiwan, Ch., 20o6. Analysis of monoethanolamine and its oxidative degradation products during $\mathrm{CO}_{2}$ absorption from flue gases: a comparative study of GC-MS, HPLC-RID, and CE-DAD analytical techniques and possible optimum combinations. Industrial and Engineering Chemistry Research 45, 2437-2451

Tian, J., Yin, Y., 2004. Novel phenomenon in the ${ }^{13} \mathrm{C}$ NMR spectra of amino acids. Amino Acids 26, $175^{-181}$

Versteeg, G.F., Oyevaar, M.H., 1989. The reaction between $\mathrm{CO}_{2}$ and diethanolamine at $298 \mathrm{~K}$. Chemical Engineering Science 44, 1264-1268

Weiland, R.H., Hatcher, N.A., Nava, J.L., 2010. Post-combustion $\mathrm{CO}_{2}$ capture with amino-acid salts. GPA Europe Meeting, Lisbon, Portugal, September 22-24

Yalkowsky, S.H., He, Y., 2003. Handbook of Aqueous solubility data. CRC Press Inc 
Yan, S., Fang, M., Luo, Z., Cen, K., 2009. Regeneration of $\mathrm{CO}_{2}$ from $\mathrm{CO}_{2}$-rich alkanolamines solution by using reduced thickness and vacuum technology: regeneration feasibility and characteristic of thin-layer solvent. Chemical Engineering and Processing: Process Intensification $48,515-523$ 



\section{Solubility of Carbon Dioxide in Aqueous Potassium L-Prolinate Solutions - Absorber Conditions}

The solubility of $\mathrm{CO}_{2}$ in aqueous potassium salt of L-proline solutions has been measured in the temperature range of 285 and $323 \mathrm{~K}$, for amino acid salt concentrations of $0.5,1,2$ and $3 \mathrm{~mol} \cdot \mathrm{dm}^{-3}$, and $\mathrm{CO}_{2}$ partial pressures relevant to flue gas conditions and up to $70 \mathrm{kPa}$. Precipitation was encountered in the system when absorbing $\mathrm{CO}_{2}$ in $3 \mathrm{~mol} \cdot \mathrm{dm}^{-3}$ potassium L-prolinate solution at $285 \mathrm{~K}$. A beneficial effect of the solid formation on the overall $\mathrm{CO}_{2}$ solubility was observed. The vapour-liquid equilibrium data from the present work (for the non-precipitating regime) were interpreted by a concentration-based chemical equilibrium model. In spite of the numerical simplicity of the model, a reasonable good description of the $\mathrm{CO}_{2}-\mathrm{AAS}-\mathrm{H}_{2} \mathrm{O}$ system could be observed. In the absence of the literature data on the equilibrium constant of the carbamate hydrolysis for L-prolinate, this parameter was calculated from the equilibrium $\mathrm{CO}_{2}$ solubility data. In addition, the enthalpy of absorption of $\mathrm{CO}_{2}$ in L-prolinate solutions was estimated using the solubility data, compared to that of MEA and other common $\mathrm{CO}_{2}$ absorbents. Potassium salt of L-proline was found to be a promising candidate for $\mathrm{CO}_{2}$ capture.

This chapter is an excerpt of scientific paper published as:

Majchrowicz, M.E., Brilman, D.W.F., 2012. Solubility of $\mathrm{CO}_{2}$ in aqueous potassium L-prolinate solutions - absorber conditions. Chemical Engineering Science 72, 35-44 


\subsection{Introduction}

Absorption with chemical reaction is a common process in the chemical industry and is used, among others, in the treatment of the industrial gas streams containing acid gases such as $\mathrm{H}_{2} \mathrm{~S}, \mathrm{NO}_{\mathrm{x}}$ and $\mathrm{CO}_{2}$. In these gas treating processes, (alkanol)amines like monoethanolamine (MEA), diethanolamine (DEA), N-methyldiethanolamine (MDEA), 2-amino-2-methyl-1-propanol (AMP), and their mixtures (with or without "activators" such as piperazine) are commonly used. These solvents, however, exhibit several drawbacks: (i) they show limited $\mathrm{CO}_{2}$ working capacity; (ii) they require the addition of corrosion inhibitors to prevent high equipment corrosion rates; (iii) they lead to high energy consumption for solvent regeneration; (iv) they suffer from the solvent losses by evaporation and from the thermal- and oxidative degradation (Kohl and Nielsen, 1997).

Aqueous solutions of amino acid salts (AAS) can be an interesting alternative for the commercially used (alkanol)amines. In general, amino acid salts are characterized by more favourable properties like low volatility (due to their ionic nature), high surface tension (important for membrane gas absorption) (Simons et al., 2010), low toxicity and high level of biodegradability (Shao and Stangeland, 2009). At the same time, they maintain (due to similar functionality) a comparable or higher chemical reactivity towards $\mathrm{CO}_{2}$ as compared to amine-based absorbents (Hook, 1997; Kumar et al., 2003; van Holst et al., 2009). Primary, aqueous amino acids (salts) were used commercially to promote the absorption rate in carbonate solutions in the Giammarco-Vetrocoke process. Over the years, their application expanded and they have been used as separate absorbents for selective removal of $\mathrm{CO}_{2}$ and $\mathrm{H}_{2} \mathrm{~S}$ from a variety of gas streams. An example of this application is Alkacid process of BASF and process by Exxon (Environment \& Energy Center), both based on sterically hindered amino acids, and the CORAL solvent of TNO (the Netherlands), originally developed to apply amino acid salt solutions in membrane gas absorption.

Design of gas-liquid contactors for $\mathrm{CO}_{2}$ removal using aqueous alkaline salts of amino acids requires, among others, information on the vapour-liquid equilibria (VLE) of these systems. Unlike for (alkanol)amine-based $\mathrm{CO}_{2}$ systems where a significant number of publications can be found in open literature, only limited information is presented for amino acid salts. A qualitative study on the $\mathrm{CO}_{2}$ absorption rate and capacity of aqueous potassium salts of several amino acids was reported by Hook (1997). Kumar et al. (2003) studied the $\mathrm{CO}_{2}$ solubility in aqueous potassium taurate solutions at temperatures from 298 to $313 \mathrm{~K}$, and $\mathrm{CO}_{2}$ partial pressures relevant to flue gas conditions (up to about $6 \mathrm{kPa}$ ). Portugal et al. (2009) reported the $\mathrm{CO}_{2}$ solubility in aqueous potassium salts of glycine, at temperatures from 293 to $351 \mathrm{~K}$, for salt concentration ranging between 0.1 and $3 \mathrm{~mol} \cdot \mathrm{dm}^{-3}$, and $\mathrm{CO}_{2}$ partial pressures up to $60 \mathrm{kPa}$. The $\mathrm{CO}_{2}$ solubility in $1 \mathrm{~mol} \cdot \mathrm{dm}^{-3}$ potassium threoninate 
solution was also measured at $313 \mathrm{~K}$. To date, no solubility data have been published for L-prolinate solutions. This solvent has been identified as a promising absorption medium because of its comparatively fast absorption kinetics, faster than, e.g., for MEA and DEA and potassium salts of other investigated amino acids (van Holst et al., 2009); in combination with a high absorption capacity, as determined in the screening effort when using a $\mathrm{CO}_{2}$ stream at atmospheric pressure.

The present research was undertaken to provide experimental solubility (vapour-liquid equilibrium-) data for $\mathrm{CO}_{2}$ in aqueous potassium salt solutions of L-proline. The experiments were performed in the temperature range of 298 and $323 \mathrm{~K}$, for amino acid salt concentrations of $0.5,1,2$ and $3 \mathrm{~mol} \cdot \mathrm{dm}^{-3}$, and $\mathrm{CO}_{2}$ partial pressures relevant to flue gas conditions and up to $70 \mathrm{kPa}$. At these conditions no precipitation will occur, whereas at higher solution concentrations and higher $\mathrm{CO}_{2}$ partial pressures the precipitates are formed (Majchrowicz et al., 2009). To study an influence of the precipitate formation on the overall $\mathrm{CO}_{2}$ solubility, a limited number of data points was measured in the 'precipitation regime' for $3 \mathrm{~mol} \cdot \mathrm{dm}^{-3}$ solution at a relatively low temperature of $285 \mathrm{~K}$. A concentration-based chemical equilibrium model similar to that by Aboudheir et al. (2003) for $\mathrm{CO}_{2}-\mathrm{MEA}-\mathrm{H}_{2} \mathrm{O}$ absorption system was used to represent the experimental VLE data (measured in the system under conditions without precipitation). The model was found to be fairly accurate and convenient in describing the single acid gas-amine equilibria. In the absence of the literature data, the apparent equilibrium constant of the carbamate hydrolysis of L-prolinate was derived from the experimental solubility data. In addition, the solubility data were used to calculate the enthalpy of absorption of $\mathrm{CO}_{2}$ in L-prolinate solvent. The results of this study should assist in the further evaluation of potassium salt of L-proline as potential solvent for $\mathrm{CO}_{2}$ capture.

\subsection{Chemistry of the process}

Amino acid is an example of an amphoteric electrolyte as it is capable of exhibiting both acidic and basic functions. Equation 3.1 presents the ionization equilibria that exist for L-proline. In water and in the absence of other solutes, the amino acid will exist as a molecule carrying a positive charge at one end and a negative charge at the other, thus constituting an electrically neutral system (form II in Equation 3.1). The amino acid in this form is called a zwitterion. In this case, the solution $\mathrm{pH}$ will be equal to the isoelectric point of the amino acid. In salt solutions or in a presence of ions other than those derived from the amino acid, some of the ionizable groups of the ampholyte may be electrically neutralized by other ions present. If a strong acid is added to the zwitterionic amino acid solution, the reaction is with the basic ion and form I is formed. A base may remove a 
proton from the ammonium group, leaving the molecule with a net negative charge - form III. This is an anion with a deprotonated amino group, which can further react with the acid gas like $\mathrm{CO}_{2}$ and $\mathrm{H}_{2} \mathrm{~S}$.

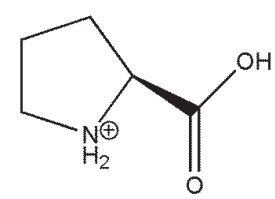

I

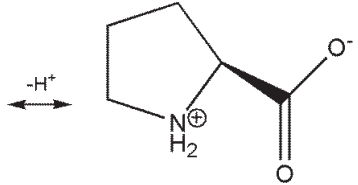

II

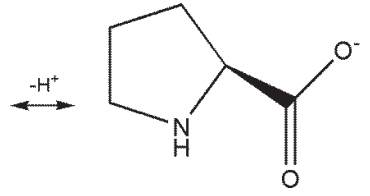

III

In the present work, the zwitterionic form of L-proline in water was neutralized with a strong base $(\mathrm{KOH})$ and the resulting aqueous amino acid salt solution was utilized in $\mathrm{CO}_{2}$ absorption experiment. There are at least two dissociation constants corresponding to the dissociation equilibria of two functional groups in amino acids. However, for the present study the second acid dissociation constant, $\mathrm{p} K_{a}$, is taken into consideration and its value at different temperatures can be found in literature (Perrin et al., 1965; Hamborg et al., 2007). Amino acid salts having an amino functional group react with $\mathrm{CO}_{2}$ in a similar way as (alkanol)amines (Kumar et al. 2003; van Holst et al., 2009). Since the amino group in proline is involved in two carbon-nitrogen bond, it is a secondary amino group. Therefore, it is expected that the overall reaction between $\mathrm{CO}_{2}$ and the amino group will result in the carbamate formation. For the overall reaction of L-prolinate with $\mathrm{CO}_{2}$, two amino acid ions are required; one forming a carbamate and one acting as a base accepting a proton. The reaction resulting in the formation of a carbamate and a protonated amino acid can be expressed (with non-reacting part $\mathrm{R} \equiv \mathrm{C}_{4} \mathrm{H}_{7}-\mathrm{COO}^{-}$, for L-prolinate) as:

$$
2 \mathrm{RNH}+\mathrm{CO}_{2} \rightleftharpoons \mathrm{RNH}_{2}^{+}+\mathrm{RNCOO}^{-}
$$

This reaction can be written as a combination of independent reactions 3.3 to 3.5 as was suggested by Kumar et al. (2003). According to the stoichiometry of reaction 3.2, a maximum $\mathrm{CO}_{2}$ absorption capacity of 0.5 (mole $\mathrm{CO}_{2}$ per mole solvent) can be expected when the carbamate formation is the only reaction. Since the amino acid carbamate may undergo hydrolysis to a bicarbonate/carbonate (depending on the solution $\mathrm{pH}$ ) and the amino acid (salt) with a deprotonated amino group, the actual $\mathrm{CO}_{2}$ loading can exceeds that theoretical value in these absorption systems. The carbamate hydrolysis reaction can be expressed as:

$$
\mathrm{RNCOO}^{-}+\mathrm{H}_{2} \mathrm{O} \rightleftharpoons \mathrm{RNH}+\mathrm{HCO}_{3}^{-}
$$


Other chemical reactions taking place in the liquid phase, along with the two abovementioned reactions, are:

Dissociation of protonated amino acid

$$
\mathrm{RNH}_{2}^{+} \rightleftharpoons \mathrm{RNH}+\mathrm{H}^{+}
$$

Hydrolysis of carbon dioxide

$$
\mathrm{CO}_{2}+\mathrm{H}_{2} \mathrm{O} \rightleftharpoons \mathrm{HCO}_{3}^{-}+\mathrm{H}^{+}
$$

Dissociation of bicarbonate

$$
\mathrm{HCO}_{3}^{-} \rightleftharpoons \mathrm{CO}_{3}^{2-}+\mathrm{H}^{+}
$$

Dissociation of water

$$
\mathrm{H}_{2} \mathrm{O} \rightleftharpoons \mathrm{H}^{+}+\mathrm{OH}^{-}
$$

\subsection{Equilibrium model}

To allow for a process evaluation at various conditions, it is desirable to have a vapour-liquid equilibrium (VLE) model that can describe $\mathrm{CO}_{2}$ absorption capacity at different absorption temperatures and $\mathrm{CO}_{2}$ partial pressures. Several models are available in literature for representing the VLE data of $\mathrm{CO}_{2}$-amine- $\mathrm{H}_{2} \mathrm{O}$ systems. These models can be generally divided into empirical models, where the non-idealities of the system are lumped into the equilibrium constants, for example, the models by Kent and Eisenberg (1976) and Aboudheir et al. (2003); and semi-empirical excess Gibbs free energy or activity coefficient models that account for the non-idealities in the liquid phase by taking into account short and long term interactions between molecular and ionic species present in the solution. Examples of the latter approach are the Deshmukh-Mather (1981) method, the electrolyteNRTL model of Chen and Evans (1989) and Clegg and Pitzer (1992). In the present work, a more practical concentration-based approach was chosen above a more fundamental activity-based model to represent the VLE data measured for potassium salt of L-proline. Studies by, for example, Kent and Eisenberg (1976), where an empirical model described well the $\mathrm{CO}_{2}$-amine- $\mathrm{H}_{2} \mathrm{O}$ system behaviour for loadings between 0.2 and 0.7 (mole $\mathrm{CO}_{2}$ per mole solvent), have shown that this type of approach is very useful and that the added value of more rigorous thermodynamic models is often not sufficient to justify additional efforts 
required. This was also shown when modelling $\mathrm{CO}_{2}-\mathrm{AAS}-\mathrm{H}_{2} \mathrm{O}$ systems. Kumar et al. (2003) studied the absorption capacities of $\mathrm{CO}_{2}$ in aqueous potassium taurate solution and the Deshmukh-Mather model was originally applied to represent the experimental VLE data. Since a limited change of the solution ionic strength (at certain absorption temperature) with $\mathrm{CO}_{2}$ liquid loading and amino acid salt concentration was observed, the binary interaction parameters in the extended Debye-Hückel expression were neglected and the model was essentially simplified to method similar to the one presented by Kent and Eisenberg (1976); with the amine deprotonation and carbamate hydrolysis constants assumed to be adjustable fit parameters. An average error in the prediction of $\mathrm{CO}_{2}$ partial pressure of $17 \%$ was reported. Portugal et al. (2009) applied both methods to describe $\mathrm{CO}_{2}$ solubility in potassium glycinate solutions and observed similar inaccuracies in the models predictions. The average relative deviations presented by the Deshmukh-Mather and the Kent-Eisenberg methods were $22 \%$ and $\mathbf{2 0} \%$, respectively.

In the present work, the VLE model for the $\mathrm{CO}_{2}-\mathrm{MEA}-\mathrm{H}_{2} \mathrm{O}$ system, as used by Aboudheir et al. (2003), served as a basis to correlate $\mathrm{CO}_{2}$ solubility in potassium L-prolinate solution; of course, taking into account solvent-specific parameters for the protonation equilibria, carbamate formation and $\mathrm{CO}_{2}$ physical solubility in the solvent under consideration. The following equilibrium constants (associated with independent chemical reactions 3.3 to 3.7 were incorporated in the model:

$$
\begin{gathered}
K_{\text {carb }}=\frac{[\mathrm{RNH}]\left[\mathrm{HCO}_{3}^{-}\right]}{\left[\mathrm{RNCOO}^{-}\right]} \\
K_{\text {ama }}=\frac{[\mathrm{RNH}]\left[\mathrm{H}^{+}\right]}{\left[\mathrm{RNH}_{2}^{+}\right]} \\
K_{\mathrm{CO}_{2}}=\frac{\left[\mathrm{HCO}_{3}^{-}\right]\left[\mathrm{H}^{+}\right]}{\left[\mathrm{CO}_{2}\right]} \\
K_{\mathrm{HCO}_{3}^{-}}=\frac{\left[\mathrm{CO}_{3}^{2-}\right]\left[\mathrm{H}^{+}\right]}{\left[\mathrm{HCO}_{3}^{-}\right]} \\
K_{\mathrm{H}_{2} \mathrm{O}}=\left[\mathrm{H}^{+}\right]\left[\mathrm{OH}^{-}\right]
\end{gathered}
$$

The temperature dependence of the equilibrium constants is expressed as (Aboudheir et al., 2003; Benamor et al., 2005):

$$
\ln K_{i}=\frac{a_{i}}{T}+b_{i} \ln T+c_{i}
$$


where $a_{i}-c_{i}$ are constants. Values of these constants for reactions other than reaction 3.3 were taken from literature - see Table 3.1. These correlations are well established and have been utilized in many VLE models (Austgen et al., 1989; Li and Mather, 1994).

Table 3.1: Coefficients for the reaction equilibrium constants used in this work (all $K_{i}$ values are on $\mathrm{mol} \cdot \mathrm{dm}^{-3}$ basis)

\begin{tabular}{lccccl}
\hline Parameter & $a_{i}$ & $b_{i}$ & $c_{i}$ & $T$ range [K] & Source \\
\hline$K_{\text {ama }}$ & -2865.5 & 7.1627 & -55.974 & $292-355$ & Hamborg et al. (2007) \\
$K_{\mathrm{CO}_{2}}$ & -12092.1 & -36.7816 & 235.482 & $273-498$ & Edwards et al. (1978) \\
$K_{\mathrm{HCO}}-$ & -12431.7 & -35.4819 & 220.067 & $273-498$ & Edwards et al. (1978) \\
$K_{\mathrm{H}_{2} \mathrm{O}}$ & -13445.9 & -22.4773 & 140.932 & $273-498$ & Edwards et al. (1978) \\
\hline
\end{tabular}

Due to the lack of experimental data for the carbamate hydrolysis constant, $K_{c a r b}$, this constant was used in the model as the sole fit parameter. By doing this, any remaining system non-idealities are then automatically lumped into this equilibrium constant. A difference between the $\mathrm{CO}_{2}$-amine- $\mathrm{H}_{2} \mathrm{O}$ system and the system with an amino acid salt is found in the charge balance of the ionic species in the liquid phase. The following assumptions were made when deriving the charge balance of amino acid salt-based $\mathrm{CO}_{2}$ capture system: (i) a protonated amino acid is a zwitterion and is treated as an electrically neutral (molecular specie), (ii) a deprotonated amino acid able to react with $\mathrm{CO}_{2}$ has a single negative charge (anion), (iii) a carbamate specie has a double negative charge, (iv) the counter ion concentration is the same as the initial amino acid salt concentration. With this, the following electroneutrality, amine and $\mathrm{CO}_{2}$ balances were formulated:

$$
\begin{gathered}
{\left[\mathrm{K}^{+}\right]+\left[\mathrm{H}^{+}\right]=[\mathrm{RNH}]+2\left[\mathrm{RNCOO}^{-}\right]+\left[\mathrm{HCO}_{3}^{-}\right]+2\left[\mathrm{CO}_{3}^{2-}\right]+\left[\mathrm{OH}^{-}\right]} \\
{[\mathrm{RNH}]_{0}=[\mathrm{RNH}]+\left[\mathrm{RNCOO}^{-}\right]+\left[\mathrm{RNH}_{2}^{+}\right]} \\
\alpha[\mathrm{RNH}]_{0}=\left[\mathrm{CO}_{2}\right]+\left[\mathrm{RNCOO}^{-}\right]+\left[\mathrm{HCO}_{3}^{-}\right]+\left[\mathrm{CO}_{3}^{2-}\right]
\end{gathered}
$$

Given $\mathrm{CO}_{2}$ partial pressure of the acid gas-liquid equilibrium system, the concentration of molecular $\mathrm{CO}_{2}$ in the solution was obtained using the Henry's law relationship:

$$
p_{\mathrm{CO}_{2}}=\frac{\left[\mathrm{CO}_{2}\right] R T}{m_{\mathrm{CO}_{2}}}
$$

For gas solubility in aqueous electrolyte solutions, the model proposed by Weisenberger and Schumpe (1996) was used to calculate the physical solubility of $\mathrm{CO}_{2}$ in aqueous potassium L-prolinate solution: 


$$
\log \left(\frac{m_{\mathrm{CO}_{2} \mathrm{H}_{2} \mathrm{O}}}{m_{\mathrm{CO}_{2}}}\right)=\Sigma\left(h_{i}+h_{g}\right) c_{i}
$$

where $m_{\mathrm{CO}_{2}, \mathrm{H}_{2} \mathrm{O}}$ and $m_{\mathrm{CO}_{2}}$ denote the gas solubility in pure water and in the salt solution, respectively, and $c_{i}$ is molar concentration of the salt. The ion-specific Schumpe parameters, $h_{i}$, (of ions other than L-prolinate) and the gas-specific constant, $h_{g}$, of $\mathrm{CO}_{2}$ were obtained from Weisenberger and Schumpe (1996); whereas the L-prolinate ion-specific parameter was taken from van Holst et al. (2008). A linear temperature dependence of the gas-specific constant was taken into account. The distribution coefficient for $\mathrm{CO}_{2}$ in water was derived from the following correlation by Versteeg et al. (1988):

$$
m_{\mathrm{CO}_{2}, \mathrm{H}_{2} \mathrm{O}}=3.54 \cdot 10^{-7} \mathrm{RT} \exp \left(\frac{2044}{T}\right)
$$

The set of nine non-linear Equations 3.8 to 3.12 and 3.14 to 3.17 was solved using Matlab program. The input data of the model include temperature, initial absorbent concentration, $\mathrm{CO}_{2}$ partial pressure and a guess-value for the $\mathrm{pH}$ of the solution. Using this guessed value for the $\mathrm{pH}$, the set of equations can be solved for the species concentrations without excessive numerical efforts; as reported necessary by Aboudheir et al. (2003). On basis of the closure of the balances, the (initial) guess of the $\mathrm{pH}$ of the solution can be adjusted until a complete solution of the system of equations is obtained. This non-trivial solution method proved to be fast and robust, without having to solve the non-linear set of stiff equations directly. A schematic overview of the model structure is presented in Figure 3.1. A performance of the model was tested by modelling $\mathrm{CO}_{2}$ solubility in aqueous MEA solution. In this case, the equilibrium constants $K_{\text {carb }}$ and $K_{\text {ama }}$ representing amine reactions were obtained from Aboudheir et al. (2003). 


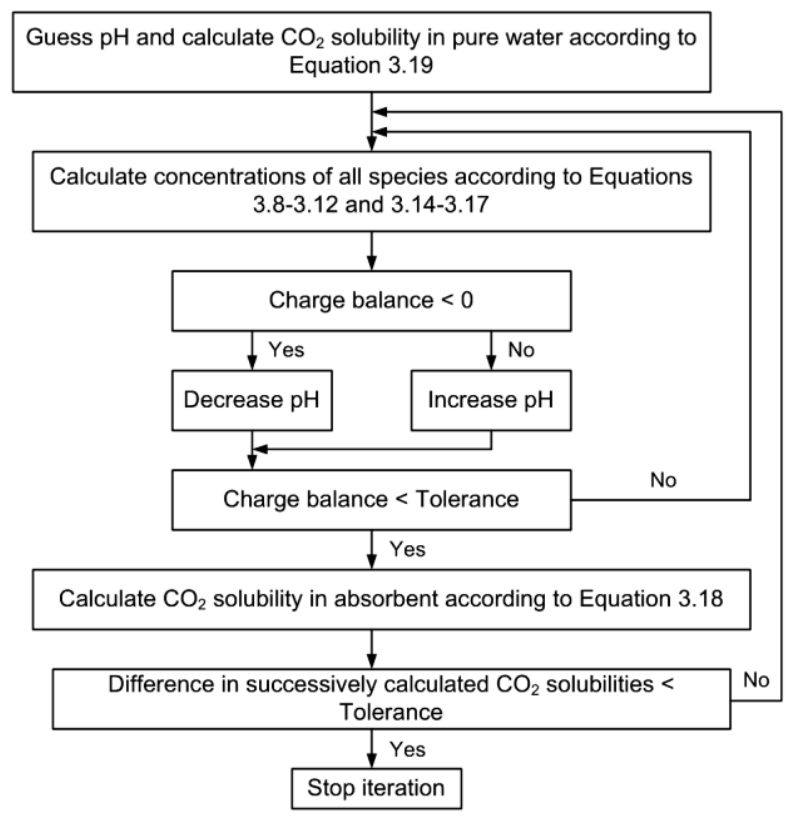

Figure 3.1: Schematic overview of the model structure

\subsection{Experimental section}

The $\mathrm{CO}_{2}$ (min. 99.99 mol\%) and $\mathrm{N}_{2}$ (min. 99.999 mol\%) gases used were obtained from Linde Gas. L-proline ( $(S)$-pyrrolidine-2-carboxylic acid, $\left.\mathrm{C}_{5} \mathrm{H}_{9} \mathrm{NO}_{2}, \geq 98.5 \%\right), \mathrm{KOH}$ ( $\geq 85.0 \%$; with the actual purity determined accurately by titration), MEA (2-aminoethanol, $\mathrm{C}_{2} \mathrm{H}_{7} \mathrm{NO}, \geq 99.0 \%$ ) were purchased from Sigma-Aldrich and were utilized without further purification. Potassium salt of L-proline was prepared by neutralizing the amino acid dissolved in deionized, double-distilled water by using an equimolar quantity of potassium hydroxide. The actual concentration of a solution was determined potentiometrically by titrating with a standard $1.000 \mathrm{~mol} \cdot \mathrm{dm}^{-3} \mathrm{HCl}$ solution.

Two experimental set-ups were used to measure $\mathrm{CO}_{2}$ solubility in the considered chemical solvents. The $\mathrm{CO}_{2}$ solubility at acid gas partial pressures relevant to flue gas conditions $(<15 \mathrm{kPa})$ was measured using the set-up and experimental procedure similar to those reported by Kumar et al. (2003). The set-up consisted of a double-walled glass reactor $\left(\cong 1.85 \mathrm{dm}^{3}\right), \mathrm{CO}_{2}$ gas supply vessel, $\mathrm{CO}_{2}$ and $\mathrm{N}_{2}$ mass flow controllers from Brooks Instruments and IR $\mathrm{CO}_{2}$ gas analyzer (Maihak). The reactor was equipped with a high 
intensity gas inducing stirrer, a digital pressure sensor (Heise) and two PT1oo temperature sensors (in the liquid and gas phases). It was heated by a water bath (Tamson). The gas supply vessel was equipped with a digital pressure sensor (Druck) and a PT1oo temperature sensor. A known, fixed amount of a fresh amino acid salt solution (or amine) $\left(\cong 1.00 \mathrm{dm}^{3}\right)$ was used in all experiments. To reduce the experiment duration, a known amount of pure $\mathrm{CO}_{2}$ from the calibrated gas supply vessel was used to pre-load (but not saturate) the solvent solution to some extent before starting the low $\mathrm{CO}_{2}$ partial pressure experiment. A liquid sample was collected from the equilibrated system, immobilized in a known amount of $1.000 \mathrm{~mol} \cdot \mathrm{dm}^{-3}$ alkaline hydroxide solution, and analyzed for the (dissolved) $\mathrm{CO}_{2}$ concentration using an analytical method similar to that described in Blauwhoff et al. (1984). Concentration of the solvent in the equilibrium cell was also checked. Change of the solvent concentration during one set of experiments (consisting of maximum 3-4 equilibrium conditions) at the end of the series was always less than $3 \%$.

Experimental data for $\mathrm{CO}_{2}$ partial pressures above $15 \mathrm{kPa}$ were obtained in the second set-up which consisted of a double-walled glass reactor $\left(\cong 1.68 \mathrm{dm}^{3}\right)$ and $\mathrm{CO}_{2}$ gas supply vessel $\left(\cong 0.52 \mathrm{dm}^{3}\right)$. The reactor was equipped with a high intensity gas inducing stirrer, a digital pressure sensor (Heise) and a PT-10o temperature sensor (in the liquid phase). It was heated by a water bath (Tamson). The gas supply vessel was equipped with a digital pressure sensor (Druck) and a PT-10o temperature sensor. In this experiment, a fresh solvent solution ( $\cong 0.80 \mathrm{dm}^{3}$ ) was introduced into the absorption cell and known portions of pure $\mathrm{CO}_{2}$ were added to the reactor. The amount of $\mathrm{CO}_{2}$ absorbed was calculated from the ideal gas law with a correction for the gas phase non-ideality by applying a compressibility factor $Z=f\left(p_{\mathrm{CO}_{2}}, T\right)$ (Turlington and McKetta, 1961; Perry and Green, 1965). More details about the set-up configuration and the experimental procedure can found in work by van Holst et al. (2007) and Portugal et al. (2009).

\subsection{Results and discussion}

To validate the experimental methods used in the present work, a series of experiments on $\mathrm{CO}_{2}$ solubility in the MEA solvent was performed. The $\mathrm{CO}_{2}$ solubility in $5 \mathrm{~mol} \cdot \mathrm{dm}^{-3}$ MEA solution at $298 \mathrm{~K}$ was obtained from the continuous mode experiments, whereas the vapour-liquid equilibrium data for $2.5 \mathrm{~mol} \cdot \mathrm{dm}^{-3}$ solution at $313 \mathrm{~K}$ were measured in the batch mode set-up. The results from this study are shown in Figure 3.2. In this figure, the VLE data from the present work are compared with those published in literature, and a good agreement can be observed. 


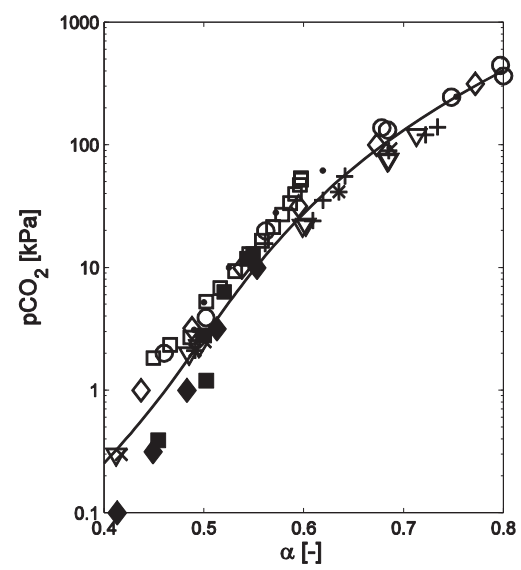

Figure 3.2: Comparison of experimental and literature data of $\mathrm{CO}_{2}$ equilibrium partial pressure over 2.5 M MEA at $T=313 \mathrm{~K}: \square$, this work; +, Shen and Li (1992); $\nabla$, Jones et al. (1959); O, Lee et al (1974); $\diamond$, Lee et al. (1976); $\times$, Austgen and Rochelle (1991), •, Song et al. (1996); *, Portugal et al.

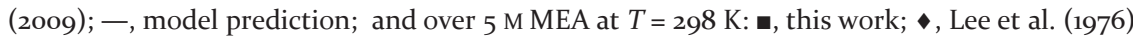

Only for the batch mode experiments the trend at lower $p_{\mathrm{CO}_{2}}$ (below $2 \mathrm{kPa}$ ) is not correct. However, this is commonly encountered for this measurement method (Portugal et al., 2009). In this figure, a $p_{\mathrm{CO}_{2}}-\alpha$ curve calculated by the VLE-model for $2.5 \mathrm{~mol} \cdot \mathrm{dm}^{-3} \mathrm{MEA}$ solution at $313 \mathrm{~K}$ is included. At $\mathrm{CO}_{2}$ loadings of less than o.6 (mole $\mathrm{CO}_{2}$ per mole solvent), the model predictions are well in line with the experimental VLE data. This loading range is of most interest for the $\mathrm{CO}_{2}$ capture industrial processes utilizing (alkanol)amines, where the lean $\mathrm{CO}_{2}$ loading ranges from about 0.2 to 0.3 and the rich $\mathrm{CO}_{2}$ loading is in the range between 0.4 and 0.6 (Kohl and Nielsen, 1997). At loading values of less than o.6, the average percentage error between the predicted and the experimental alpha value (this study only) was found to be $8.1 \%$. This inaccuracy in the model predictions is well in line with the one reported by Aboudheir et al. (2003).

Figure 3.3 presents the solubility of $\mathrm{CO}_{2}$ in potassium salt of L-proline for different molar concentrations at temperatures 298 and $313 \mathrm{~K}$. In Figure 3.4, the $\mathrm{CO}_{2}$ solubility in $3 \mathrm{~mol} \cdot \mathrm{dm}^{-3}$ L-prolinate solution as a function of the system temperature is given. In these figures, the solid lines show the $p_{\mathrm{CO}_{2}}-\alpha$ curves as calculated by the model (for systems without precipitation). The observed effect of temperature and initial absorbent concentration on the overall $\mathrm{CO}_{2}$ solubility follows the trends reported in literature for $\mathrm{CO}_{2}$-amine- $\mathrm{H}_{2} \mathrm{O}$ systems (Jones et al., 1959; Lee and Otto, 1974; Lee et al., 1976; Austgen and Rochelle, 1991; Shen and Li, 1992). 
For a given $\mathrm{CO}_{2}$ partial pressure and absorption temperature (e.g. at 298 or $313 \mathrm{~K}$ ), an increase in L-prolinate concentration from 0.5 to $3 \mathrm{~mol} \cdot \mathrm{dm}^{-3}$ results in a reduction of the relative $\mathrm{CO}_{2}$ liquid by, on average, $27 \%$. The effect of $\mathrm{CO}_{2}$ partial pressure on the overall absorbent loading was also investigated. For $298 \mathrm{~K}$, a change of $\mathrm{CO}_{2}$ partial pressure from 2 to $15 \mathrm{kPa}$ results in an increase of $\mathrm{CO}_{2}$ liquid loading by approximately $20 \%$ (for all studied amino acid salt concentrations). For $313 \mathrm{~K}$, the effect of $\mathrm{CO}_{2}$ partial pressure on the absorbent loading is especially pronounced at lower concentrations of L-prolinate. For $0.5 \mathrm{~mol} \cdot \mathrm{dm}^{-3} \mathrm{~L}$-prolinate solution, an increase of $\mathrm{CO}_{2}$ liquid loading by $30 \%$ when changing pressure from 2 to $15 \mathrm{kPa}$ can be observed, whereas for $3 \mathrm{~mol} \cdot \mathrm{dm}^{-3}$ solution a $50 \%$ lower sensitivity towards $\mathrm{CO}_{2}$ pressure is found. For these systems, in the temperature range of 298-325 K, further increase in $p_{\mathrm{CO}_{2}}$ does not result in a remarkably change in the absorbent loading.
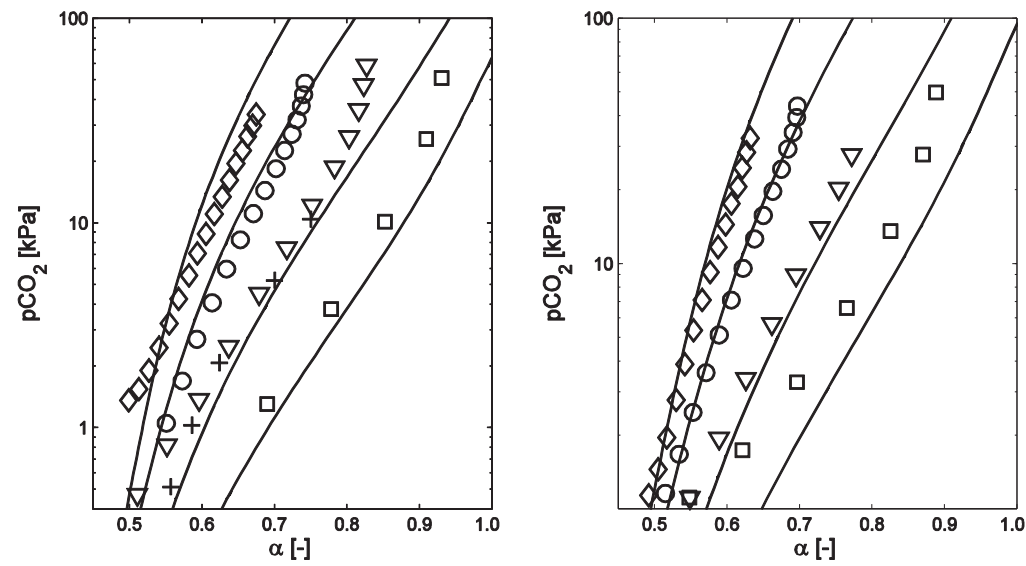

Figure 3.3: $\mathrm{CO}_{2}$ equilibrium partial pressure over potassium salt of L-proline. Effect of absorbent concentration at $T=298 \mathrm{~K}$ (left) and $T=313 \mathrm{~K}$ (right); $\square$, o.5 M; $\nabla, 1 \mathrm{M} ; \mathrm{O}, 2 \mathrm{M} ; \diamond, 3 \mathrm{M} ;+, 1 \mathrm{M}$ (continuous mode); -, model prediction 


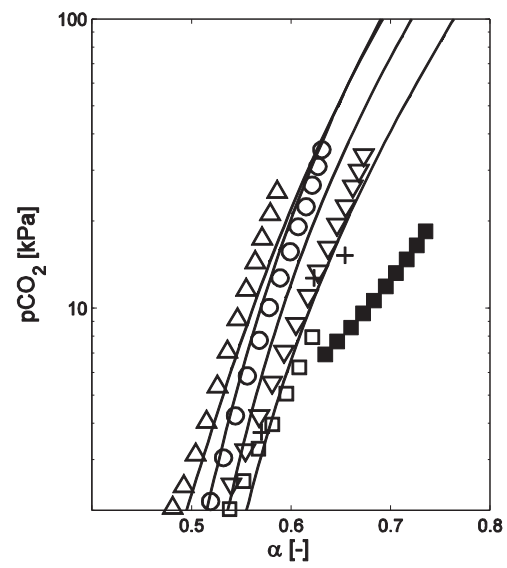

Figure 3.4: $\mathrm{CO}_{2}$ equilibrium partial pressure over $3 \mathrm{M}$ potassium L-prolinate solution. Effect of temperature and precipitation. $\square, T=285 \mathrm{~K} ; \nabla, T=298 \mathrm{~K} ; \mathrm{O}, T=313 \mathrm{~K} ; \Delta, T=323 \mathrm{~K} ;+, T=298 \mathrm{~K}$ (continuous mode); $\mathbf{\square}, T=285 \mathrm{~K}$ (precipitation); - , model prediction

Precipitation of potassium bicarbonate was encountered when absorbing $\mathrm{CO}_{2}$ in $3 \mathrm{~mol} \cdot \mathrm{dm}^{-3}$ L-prolinate solution at $285 \mathrm{~K}$ above $6 \mathrm{kPa}$ of $\mathrm{CO}_{2}$. The $\mathrm{CO}_{2}$ absorption with precipitation, at lower absorber temperatures $(T=\mathbf{2 7 5}-\mathbf{2 8 3} \mathrm{K})$, is specifically utilized in the chilled ammonia process (Darde et al., 2008). The effect of precipitation in amino acid salt solutions was therefore investigated in the present study. For $\mathrm{CO}_{2}-\mathrm{AAS}-\mathrm{H}_{2} \mathrm{O}$ systems, the solid phase formation was earlier reported at ambient temperatures $(T=298-313 \mathrm{~K})$ for a series of sterically and non-sterically hindered amino acids by Hook (1997) and Majchrowicz et al. (2009), for potassium salt of taurine by Kumar et al. (2003). It has been shown that as a result of precipitation, higher loadings of the solvent at lower partial pressures of $\mathrm{CO}_{2}$ (compared to a situation without the solids) can be obtained; which is now found for potassium salt of L-proline. A further observation is that precipitation induces a higher sensitivity of the solvent absorption capacity (in mole $\mathrm{CO}_{2}$ per mole solvent), as can be noticed from the slope of the series of closed symbols (squares) in Figure 3.4 when compared to open squares in the same figure. To improve the $\mathrm{CO}_{2}$ capture process, the concept of the formation of precipitates in $\mathrm{CO}_{2}-\mathrm{AAS}-\mathrm{H}_{2} \mathrm{O}$ systems is considered in the DECAB process (Feron and ten Asbroek, 2004). The pilot plant tests showed that this process can be more compact and more energy efficient (i.e. it requires less thermal energy for solvent regeneration due to increased rich loading) when compared to commercial (alkanol)amines. It is further indicated that for a certain $\mathrm{CO}_{2}$ liquid loading, the $\mathrm{CO}_{2}$ pressure is around "one-tenth of the extrapolated equilibrium pressure assuming that no precipitation is occurring". For L-prolinate, at a certain solution loading, the corresponding 
$\mathrm{CO}_{2}$ partial pressure is up to half the (extrapolated) value assuming no precipitation takes place.

Figure 3.5 shows a parity plot of the fitted and experimental $\mathrm{CO}_{2}$ liquid loadings for all studied conditions. A reasonable good fit between the predicted and experimental $\alpha$ values can be observed. For loadings higher than 0.3 (mole $\mathrm{CO}_{2}$ per mole solvent), an average error of $13.3 \%$ in the model prediction was found. Higher deviations in the model prediction were encountered for liquid $\mathrm{CO}_{2}$ loading in the range of o.1-0.3.

Besides the $p_{\mathrm{CO}_{2}}-\alpha$ curves, the equilibrium model was used to estimate concentration of the liquid-phase species as a function of $\mathrm{CO}_{2}$ liquid loading. Information on the species distribution may be important, for example, for kinetic analysis but can also contribute to a better understanding of the process. Figure 3.6 presents the speciation equilibrium concentration profile for the $\mathrm{CO}_{2}$-loaded $1 \mathrm{~mol} \cdot \mathrm{dm}^{-3} \mathrm{~L}$-prolinate solution at $313 \mathrm{~K}$. For the same conditions, similar qualitative trends in the species distribution were found when comparing the liquid-phase concentration profile of potassium L-prolinate with that presented by Portugal et al. (2009) for potassium glycinate. The carbamate of glycinate is somewhat less stable than that of L-prolinate; which translates into (slightly) higher $\mathrm{CO}_{2}$ absorption capacity of glycinate solvent - see Figure 3.7.

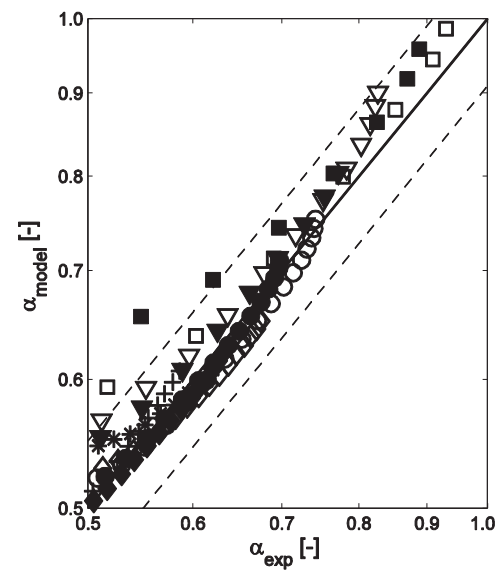

Figure 3.5: Parity plot of the predicted and experimental loading of $\mathrm{CO}_{2}$ in solution for all data analyzed. Dashed lines indicate $\pm 10 \%$ error intervals. Open symbols for $T=298 \mathrm{~K}$ and closed symbols for $T=313 \mathrm{~K}$. $\square$, o.5 M; $\nabla, 1 \mathrm{M}$; O, $2 \mathrm{M} ; \diamond, 3 \mathrm{M} ;+, 3 \mathrm{M}$ at $T=285 \mathrm{~K}$ (no solids); *, $3 \mathrm{M}$ at $T=323 \mathrm{~K}$ 


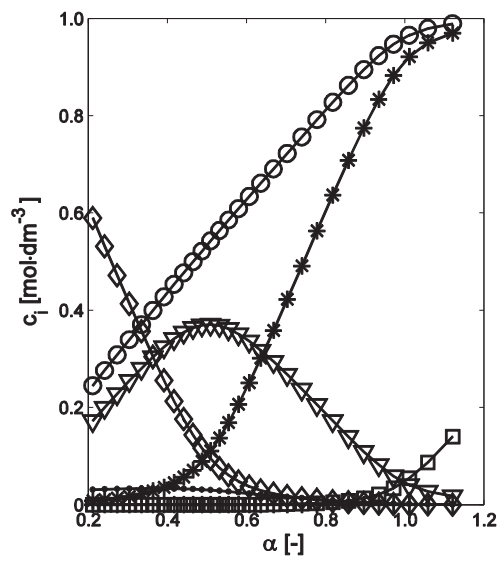

Figure 3.6: Species concentration as a function of $\mathrm{CO}_{2}$ liquid loading for $1 \mathrm{M}$ potassium L-proline solution at $T=313 \mathrm{~K} . \square, \mathrm{CO}_{2} ; \diamond, \mathrm{RNH} ; \mathrm{O}, \mathrm{RNH}_{2}^{+} ; \nabla, \mathrm{RNCOO}^{-} ; *, \mathrm{HCO}_{3}^{-} ; \bullet \bullet \mathrm{CO}_{3}^{2-} ;-, \mathrm{OH}^{-} ;+, \mathrm{H}^{+}$. Note that points represent simulation results and not experimental data. Non-reacting part, $\mathrm{R} \equiv \mathrm{C}_{4} \mathrm{H}_{7}-\mathrm{COO}^{-}$

In Figure 3.7, a comparison between $\mathrm{CO}_{2}$ solubility in $1 \mathrm{~mol} \cdot \mathrm{dm}^{-3}$ potassium L-prolinate solution with other amino acid salts and MEA is shown. From the relative positions of the equilibrium curves, it is clear that at a given $\mathrm{CO}_{2}$ partial pressure the absorption capacity is the lowest for potassium taurate and that potassium threoninate has a similar $\mathrm{CO}_{2}$ absorption capacity as MEA. Comparing potassium salts of L-proline and glycine with MEA, it can be observed that at $\mathrm{CO}_{2}$ partial pressures relevant to flue gas conditions (up to $15 \mathrm{kPa}$ ), the loading capacities of L-prolinate and glycinate are, respectively, up to 19 and $23 \%$ higher than the loading found for MEA. Of the two salts, glycinate is slightly more beneficial in terms of $\mathrm{CO}_{2}$ absorption capacity (smaller slope of the equilibrium line), which may translate into a higher cyclic loading. Potassium salt of L-proline has, however, a far higher kinetics of $\mathrm{CO}_{2}$ absorption (as compared to other investigated chemical solvents); as reported by van Holst et al. (2007). These features make L-prolinate a promising solvent for $\mathrm{CO}_{2}$ scrubbing from industrial gas streams. 


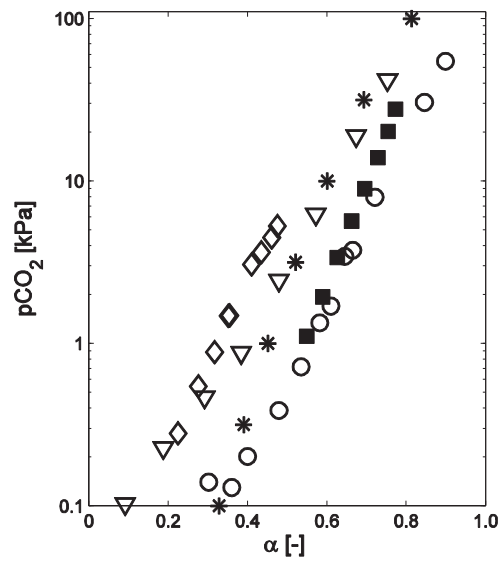

Figure 3.7: $\mathrm{CO}_{2}$ equilibrium partial pressure over $1 \mathrm{M}$ solutions of chemical solvents at $T=313 \mathrm{~K}$. L-prolinate this work; $\diamond$, taurate Kumar et al. (2003); O, glycinate Portugal et al. (2009); $\nabla$, threoninate Portugal et al. (2009); *, MEA Lee et al. (1976)

High absorption capacity towards $\mathrm{CO}_{2}$ of L-prolinate could be attributed, for example, to the physically absorbed $\mathrm{CO}_{2}$ and its contribution to the total $\mathrm{CO}_{2}$ loading (Aroua et al., 2004). Concentration of the physically absorbed $\mathrm{CO}_{2}$ for L-prolinate solution was therefore estimated from Henry's law. A clear reduction in the concentration of $\mathrm{CO}_{2}$ absorbed physically in L-prolinate solution with increasing initial amino acid salt concentration and $\alpha$ value for $298 \mathrm{~K}$ can be found. This behaviour can be explained by the 'salting out' tendency of dissolved gases as $\mathrm{CO}_{2}$ with increasing salt concentration (Bishnoi and Rochelle, 2002). For a given $\mathrm{CO}_{2}$ partial pressure and at $298 \mathrm{~K}$, this contribution is 43 and $75 \%$ higher for a $0.5 \mathrm{~mol} \cdot \mathrm{dm}^{-3}$ potassium salt of L-prolinate compared to, respectively, 1 and $3 \mathrm{~mol} \cdot \mathrm{dm}^{-3}$ solutions. Similar trend was observed for other studied temperatures. Based on the calculated data, it can be concluded that concentration of the physically absorbed $\mathrm{CO}_{2}$ is not negligible, especially for lower molarities of the solvent, but cannot explain the fact that potassium salt of L-proline can be loaded with $\mathrm{CO}_{2}$ to the observed levels.

A number of research papers indicating influence of the equilibrium constants representing amine reactions on the overall solution capacity have been published ( $\mathrm{Li}$ and Chang, 1994; Seo and Hong, 1996; Hook, 1997; Baek et al., 2000; Portugal et al., 2009). For potassium L-prolinate, the amine deprotonation equilibrium constant, $K_{a m a}$, is known and can be calculated using one of the published correlations (Perrin, 1965; Hamborg et al., 2007). No data could be found, however, for the carbamate hydrolysis equilibrium constant, $K_{\text {carb }}$. In the present work, the apparent equilibrium constants of reactions 3.8 and 3.9 were determined simultaneously using the least-squares fit to the experimental VLE data. The 
$K_{a m a}$ was included in the analysis to validate the calculation procedure used. Table 3.2 presents the optimal values of $K_{\text {ama }}$ obtained in the regression for different experimental data sets; $C_{m}$ stands for the initial solvent molarity. This table compares the fitted values with the literature data of Hamborg et al. (2007). A good agreement between the data can be reported. The fitted values of the carbamate hydrolysis equilibrium constant of L-prolinate are compared with literature data for other $\mathrm{CO}_{2}$ absorbents in Table 3.3.

Table 3.2: Fitted L-prolinate deprotonation constant, $K_{a m a}$, for different data sets

\begin{tabular}{|c|c|c|c|}
\hline $\begin{array}{c}T \\
{[\mathrm{~K}]}\end{array}$ & $\begin{array}{c}C_{m} \\
{\left[\mathrm{~mol} \cdot \mathrm{dm}^{-3}\right]}\end{array}$ & $\begin{array}{c}K_{\text {ama }}^{\text {model }} \\
{\left[\mathrm{mol} \cdot \mathrm{dm}^{-3}\right]}\end{array}$ & $\begin{array}{c}K_{\text {ama }}^{\text {lit. }} \\
{\left[\mathrm{mol} \cdot \mathrm{dm}^{-3}\right]}\end{array}$ \\
\hline 285 & 3 & $9.954 \times 10^{-12}$ & - \\
\hline 298 & 2 & $2.004 \times 10^{-11}$ & $1.736 \times 10^{-11}$ \\
\hline 298 & 3 & $1.553 \times 10^{-11}$ & $1.736 \times 10^{-11}$ \\
\hline 313 & 3 & $4.142 \times 10^{-11}$ & $3.983 \times 10^{-11}$ \\
\hline 323 & 3 & $8.224 \times 10^{-11}$ & $6.500 \times 10^{-11}$ \\
\hline
\end{tabular}

In literature, some efforts have been made to rationalize observed trends in the carbamate stability of $\mathrm{CO}_{2}$-amine- $\mathrm{H}_{2} \mathrm{O}$ systems (as in Table 3.3) (Chakraborty et al., 1986; Sartori and Savage, 1983; Rochelle et al., 2002). To fully understand the carbamate stability more than one molecular structure factor has to be taken into consideration; e.g. accessibility of various parts of molecular surface, intramolecular hydrogen bonding and variations in solvation energy (da Silva and Svendsen, 2006). Despite this complexity, some simplified correlations and concepts are useful and applicable. The stability of carbamate species can be generally related to the degree of steric hindrance as imposed by the structure of the molecule. Hindered (alkanol)amines such as AMP have low carbamate stability. These compounds still form carbamates, but they make a smaller contribution to the overall $\mathrm{CO}_{2}$ absorbed. Conversely, the carbamates of primary (alkanol)amines are relatively stable. Proline, which is a cyclic amino acid, has a molecule structure that differs from the structure of other amino acids - see Equation 3.1. Its side chain is bonded to nitrogen of the amino group as well as to carbon atom, which makes the amino group a secondary amine. Because of this, proline is also described as an imino acid. As determined in the present work, the carbamate of potassium salt of L-proline is more stable towards hydrolysis than a typical secondary (alkanol)amine (e.g. DEA), more in the range of primary (alkanol)amines (or amino acid salts). This is likely due to the unique ring structure of the molecule. In this respect, proline is probably more similar to other cyclic secondary amines as piperazine. The cyclic amines have a strong tendency to form carbamate species (da Silva and Svendsen, 2006). This is manifested, for example, in higher rates of the carbamate formation (compared to other amines); what could also be observed in the analysis of equilibrium concentration profiles - see Figure 3.6; but this requires further experimental support. 
Table 3.3: Carbamate hydrolysis constant, $K_{\text {carb }}$, for various $\mathrm{CO}_{2}$ absorbents

\begin{tabular}{lccl}
\hline Solvent & $\begin{array}{c}T \\
{[\mathrm{~K}]}\end{array}$ & $\begin{array}{c}K_{\text {carb }} \\
{\left[\mathrm{mol} \cdot \mathrm{dm}^{-3}\right]}\end{array}$ & Source \\
\hline Potassium L-prolinate & 285 & 0.014 & this work \\
& 298 & 0.028 & \\
& 313 & 0.043 & \\
Sodium glycinate & 323 & 0.057 & \\
& 291 & 0.033 & Jensen et al. (1952) \\
Potassium taurate & 298 & 0.042 & \\
Sodium $\alpha$-alaninate & 298 & 0.051 & Kumar et al. (2003) \\
Sodium $\beta$-alaninate & 291 & 0.108 & Jensen and Faurholt (1952) \\
Monoethanolamine & 291 & 0.031 & Jensen and Faurholt (1952) \\
Diethanolamine & 298 & 0.025 & Kumar et al. (2003) \\
& 298 & 0.140 & Aroua et al. (1997) \\
2-Amino-2-methyl-1-propanol & 313 & 0.268 & \\
Piperazine & 313 & $<10$ & Sartori and Savage (1983) \\
\hline
\end{tabular}

In the temperature range studied, the dependence of the equilibrium constant $K_{\text {carb }}$ with temperature can be expressed for potassium salt of L-proline by Equation 3.20. This correlation is similar to those given by Li and Shen (1993) and Haji-Sulaiman et al. (1998).

$$
K_{c a r b}=\exp \left(5.198-\frac{2607}{T}-\frac{9.2}{T^{3}}\right)
$$

The magnitude of the heat of absorption is an important factor in the thermal energy requirements of gas treating through its indirect influence on a temperature sensitivity of the vapour-liquid equilibrium curves. Several methods have been proposed in literature to determine this parameter. This includes direct calorimetric measurements, which produces accurate values but requires the use of dedicated equipment (Kim and Svendsen, 2007). This parameter can also be predicted from the reaction equilibrium constants (Posey et al., 1996) or from the partial molal enthalpies of all species present in the system (Mundhwa and Henni, 2007). Modelling of the heat of absorption is useful, for example, for a prediction of the heat effects outside the range of experimental conditions but may be complicated if not all reaction equilibrium constants are known and the non-ideality of the system is taken into account. The heats of absorption found in literature are usually derived from experimental solubility data using the Gibbs-Helmholtz formula. This is a relatively simple method that proved to be very practical in an initial phase of the solvent evaluation. However, its disadvantage lies in the fact that the differentiation process "magnifies" any inaccuracies in the VLE data (Lee et al., 1974; Kim and Svendsen, 2007). In this work, the 
major source of error was associated with a measurement of the equilibrium pressure, whereas minor errors resulted from uncertainties in the temperature measurement and determination of the solution molarity. Since the solvent phase is essentially non-volatile under the experimental conditions, approximate values of the differential heat of absorption, $\Delta H_{\text {diff }}$, of $\mathrm{CO}_{2}$ in potassium salt of L-proline can be calculated from the following form of Gibbs-Helmholtz equation (Ma'mun et al., 2005):

$$
\frac{\Delta H_{\text {diff }}}{R}=\left[\frac{\partial \ln p_{\mathrm{CO}_{2}}}{\partial\left(\frac{1}{T}\right)}\right]_{\alpha}
$$

where $p_{\mathrm{CO}_{2}}$ is partial pressure of $\mathrm{CO}_{2}$ and $\alpha$ is $\mathrm{CO}_{2}$ loading in the liquid phase.

Figure 3.8 compares the calculated values of $\Delta H_{\text {diff }}$ for L-prolinate with those reported in literature for other $\mathrm{CO}_{2}$ absorbents. A change in the absorption enthalpy with $\mathrm{CO}_{2}$ loading in the solvent is shown. In general, the enthalpy is fairly constant or slowly decreases with increasing loading till a mole ratio of about 0.5 is reached (corresponding to a formation of the carbamate). From this point, a rapid drop off in the enthalpy value is visible. This behaviour is consistent with that observed for primary and secondary (alkanol)amines, while for tertiary (alkanol)amines (as MDEA) the heat of reaction starts dropping immediately (and at lower rate compared to other amines); since no carbamate is formed. The enthalpy of absorption of L-prolinate- $\mathrm{CO}_{2}$ systems is comparable to that of DEA and similarly to this secondary alkanolamine, it also shows slight dependence on molarity of the solution; while the absence of such a relationship was reported, for example, for MEA (Lee et al., 1974). 


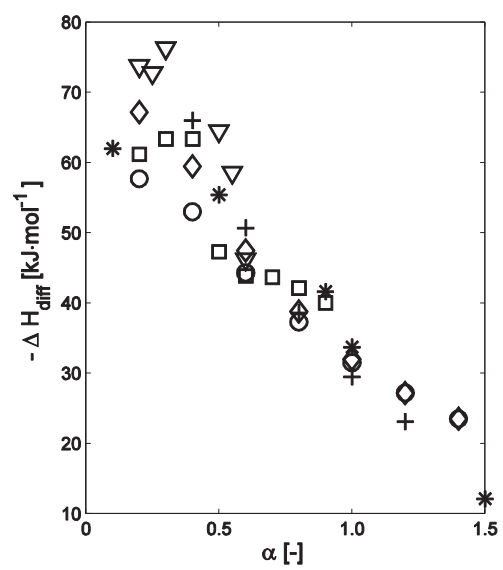

Figure 3.8: Comparison of differential enthalpy of absorption, $\Delta H_{\text {diff, }}$, of $\mathrm{CO}_{2}$ in potassium L-prolinate solution (KP) with those from literature. $\square$, o.5 M KP this work; $\nabla, 2 \mathrm{M} \mathrm{KP}$ this work; +, 2.5 M MEA Lee et al (1974); *, 2 M MDEA Jou et al. (1982); O, o.5 M DEA Lee et al. (1972); $\diamond, 2 \mathrm{M}$ DEA Lee et al. (1972)

Recently, Salazar et al. (2010) have presented the calorimetric data for the enthalpy of absorption of $\mathrm{CO}_{2}$ in sodium glycinate solutions. The heat of absorption was measured using an isothermal high-pressure flow calorimeter for $0.10 \mathrm{wt} \%$ solvent solutions, at temperatures of 313.15 and $323.15 \mathrm{~K}$, and pressure of $12 \mathrm{MPa}$. In their article, a table comparing the enthalpy of reaction for sodium glycinate solutions with those reported for other $\mathrm{CO}_{2}$ absorbents was presented. A comparison between different solvents was made based on the enthalpies of absorption at infinite dilution and at the saturated loading point of $\mathrm{CO}_{2}$. In the present work, the differential heats of absorption for $0.5 \mathrm{~mol} \cdot \mathrm{dm}^{-3}$ solutions of potassium L-prolinate (this work) and DEA (from Lee et al., 1972) were integrated following Equation 3.22 (by Arcis et al., 2007) up to the (saturated) $\mathrm{CO}_{2}$ liquid loading of o.8. The resulting absorption enthalpies are presented in Table 3.4. Other values of $\Delta H_{\text {avg }}$ reported in this table were taken from Salazar et al. (2010).

$$
\Delta H_{\text {avg }}=\frac{1}{\alpha} \int_{0}^{\alpha} \Delta H_{\text {diff }} \mathrm{d} \alpha
$$


Table 3.4: Comparison of enthalpy of absorption, $\Delta H_{a v g}$, of $\mathrm{CO}_{2}$ in potassium L-prolinate solution with those from literature

\begin{tabular}{|c|c|c|c|c|}
\hline Solvent & $\begin{array}{c}-\Delta H_{a v g} \\
{\left[\mathrm{~kJ} \cdot \mathrm{mol}^{-1}\right]}\end{array}$ & $\begin{array}{c}\alpha \\
{[-]}\end{array}$ & $\begin{array}{c}T \\
{[\mathrm{~K}]}\end{array}$ & $\begin{array}{c}x \\
{[w t \%]}\end{array}$ \\
\hline Monoethanolamine & 81.0 & & 298.15 & 0.10 \\
\hline \multirow[t]{3}{*}{ Diethanolamine } & 68.8 & & 299.82 & 0.10 \\
\hline & 69.1 & 0.87 & 299.82 & 0.20 \\
\hline & 74.7 & & 349.82 & 0.20 \\
\hline Diethanolamine* & 50.8 & 0.80 & $(298.15-413.15)$ & 5.00 \\
\hline \multirow[t]{6}{*}{ N-Methyldiethanolamine } & 50.3 & & 298.15 & 0.10 \\
\hline & 49.1 & & 313.15 & 0.10 \\
\hline & 50.3 & 1.00 & 323.15 & 0.10 \\
\hline & 50.3 & 1.07 & 313.15 & 0.10 \\
\hline & $55 \cdot 7$ & 0.95 & 333.15 & 0.10 \\
\hline & 49.6 & 1.26 & 322.50 & 0.15 \\
\hline Diglycolamine & 82.7 & & $288.71,333.15$ & 0.10 \\
\hline 2-Amino-2-methyl-1-propanol & 70.4 & 1.32 & 322.50 & 0.15 \\
\hline \multirow[t]{2}{*}{ Sodium glycinate } & 72.5 & 0.90 & 313.15 & 0.10 \\
\hline & 59.5 & 0.86 & 323.15 & 0.10 \\
\hline Potassium L-prolinate ${ }^{* *}$ & $54 \cdot 3$ & 0.80 & $(298.37-313.83)$ & 7.50 \\
\hline
\end{tabular}

"Calculated based on data of Lee et al. (1974); Calculated using present data

It can be observed that $\Delta H_{\text {avg }}$ for potassium L-prolinate is of similar magnitude than those for sodium glycinate; however, it is slightly higher than that for MDEA and lower compared to MEA and other (alkanol)amines. This may indicate moderate energy demands for L-prolinate regeneration and confirm that this amino acid can be a good $\mathrm{CO}_{2}$ absorbent alternative. However, to perform the complete energetic evaluation of this system, a relation between the heat of absorption, the overall regeneration heat duty and the process parameters needs to be considered (Oexmann and Kather, 2010).

\subsection{Conclusions}

The solubility of $\mathrm{CO}_{2}$ in aqueous potassium salt of L-proline was measured in the temperature range of 285-323 $\mathrm{K}$, for amino acid salt concentrations of $0.5,1,2$ and $3 \mathrm{~mol} \cdot \mathrm{dm}^{-3}$, and $\mathrm{CO}_{2}$ partial pressures relevant to flue gas conditions and up to $70 \mathrm{kPa}$. During absorption of $\mathrm{CO}_{2}$ in $3 \mathrm{~mol} \cdot \mathrm{dm}^{-3} \mathrm{~L}$-prolinate solutions at $285 \mathrm{~K}$, precipitation was encountered; increasing $\mathrm{CO}_{2}$ absorption capacity of the system. Higher $\mathrm{CO}_{2}$ liquid loadings and fast absorption kinetics (van Holst et al., 2007) indicate that this amino acid can be a 
good absorbent alternative. The data on $\mathrm{CO}_{2}$ solubility and heat of absorption provided in this work are required when determining the energetic demands of this system. 


\section{Nomenclature}

$\begin{array}{ll}c & \text { concentration }\left[\mathrm{mol} \cdot \mathrm{dm}^{-3}\right] \\ \Delta H & \text { enthalpy change }\left[\mathrm{kJ} \cdot \mathrm{mol}^{-1}\right] \\ h_{i} & \text { interaction parameter in Schumpe model for ions }\left[\mathrm{dm}^{3} \cdot \mathrm{mol}^{-1}\right] \\ h_{g} & \text { interaction parameter in Schumpe model for gases }\left[\mathrm{dm}^{3} \cdot \mathrm{mol}^{-1}\right] \\ K & \text { equilibrium constant }\left[\mathrm{mol} \cdot \mathrm{dm}^{-3}\right] \\ m & \text { physical distribution coefficient }[-] \\ p_{\mathrm{CO}_{2}} & \text { carbon dioxide partial pressure }[\mathrm{kPa}] \\ R & \text { universal gas constant }\left[\mathrm{J} \cdot \mathrm{mol}^{-1} \cdot \mathrm{K}^{-1}\right] \\ T & \text { temperature }[\mathrm{K}] \\ \alpha & \text { loading }\left[\text { mole } \mathrm{CO}_{2} \text { per mole solvent }\right]\end{array}$




\section{Bibliography}

Aboudheir, A., Tontiwachwuthikul, P, Chakma, A., Idem R., 2003. Kinetics of the reactive absorption of carbon dioxide in high $\mathrm{CO}_{2}$-loaded concentrated aqueous monoethanolamine solutions. Chemical Engineering Science 58, 5195-5210

Arcis, H., Rodier, L., Coxam, J-Y., 2007. Enthalpy of solution of $\mathrm{CO}_{2}$ in aqueous solutions of 2-amino-2-methyl-1-propanol. The Journal of Chemical Thermodynamics 39, 878-887

Aroua, M.K., Amor, A.B., Haji-Sulaiman, M.Z., 1997. Temperature dependence of the equilibrium constant for the formation of carbamate from diethanolamine. Journal of Chemical Engineering Data 42, 692-696

Aroua, M.K., Salleh, R.M., 2004. Solubility of $\mathrm{CO}_{2}$ in aqueous piperazine and its modeling using the Kent-Eisenberg approach. Chemical Engineering and Technology 27, 65-70

Austgen, D.M., Rochelle, G.T., Peng, X., Chen C.C., 1989. Model of vapor-liquid equilibria for aqueous acid gas alkanolamine systems using the electrolyte NRTL equation. Industrial and Engineering Chemistry Research 28, 1060-1073

Austgen, D.M., Rochelle, G.T., 1991. Model of vapor-liquid for aqueous acid gas-alkanolamine systems. Representation of $\mathrm{H}_{2} \mathrm{~S}$ and $\mathrm{CO}_{2}$ solubility in aqueous $\mathrm{MDEA}$ and $\mathrm{CO}_{2}$ solubility in aqueous mixtures of MDEA with MEA or DEA. Industrial and Engineering Chemistry Research 30 $543-555$

Baek, J.I., Yoon, J.H., Eum, H.M., 20oo. Prediction of equilibrium solubility of carbon dioxide in aqueous 2-amino-2-methyl-1,3-propanediol solutions. Korean Journal of Chemical Engineering 17, $484-487$

Benamor, A., Aroua, M.K., 2005. Modeling of $\mathrm{CO}_{2}$ solubility and carbamate concentration in DEA MDEA and their mixtures using the Deshmukh-Mather model. Fluid Phase Equilibria 231, 150-162

Bishnoi, S., Rochelle, G.T., 200o. Physical and chemical solubility of carbon dioxide in aqueous methyldiethanolamine. Fluid Phase Equilibria 168, 241-258

Blauwhoff, P.M., Versteeg, G.F., van Swaaij, W.M., 1984. A study on the reaction of between $\mathrm{CO}_{2}$ and alkanolamines in aqueous solutions. Chemical Engineering Science 39, 207-225

Chakraborty, A.K., Bischoff, K.B., Astarita, G., Damewood, J.R., 1986. Molecular orbital approach to substituent effects in amine- $\mathrm{CO}_{2}$ interactions. Journal of the American Chemical Society 110, $6947-6954$

Chen, C.C., Evans, L.B., 1986. A local composition model for the excess Gibbs energy of aqueouselectrolyte systems. American Institute of Chemical Engineers Journal 32, 444-454 
Clegg, S.L., Pitzer, K.S., 1992. Thermodynamics of multicomponent, miscible, ionic-solutionsgeneralized equations for symmetrical electrolytes. Journal of Physical Chemistry 96, 3513-3520

Darde, V., Thomsen, K., Well W., Stenby E., 2008. Chilled ammonia process for $\mathrm{CO}_{2}$ capture. ICPWS XV Berlin, September 8-11

Deshmukh, R.D., Mather, A.E., 1981. A mathematical model for equilibrium solubility of hydrogen sulfide and carbon dioxide in aqueous alkanolamine solutions. Chemical Engineering Science 36, $355-362$

Edwards, J.T., Maurer, G., Newman, J., Prausnitz, J.M., 1978. Vapor-liquid equilibria in multicomponent aqueous solutions of volatile weak electrolytes. American Institute of Chemical Engineers Journal 24, 966-976

Feron, P.H.M., ten Asbroek, N.A.M., 2004. New solvents based on amino-acid salts for $\mathrm{CO}_{2}$ capture from flue gases. GHGT-7, Vancouver, Canada

Haji-Sulaiman, M.K., Aroua, M.K., Benamor, A., 1998. Analysis of equilibrium data of $\mathrm{CO}_{2}$ in aqueous solutions of diethanolamine (DEA), methyldiethanolamine (MDEA) and their mixtures using the modified Kent-Eisenberg model. Chemical Engineering Research and Design 78, 961-968

Hamborg, E.S., Niederer, J.P.M., Versteeg, G.F., 2007. Dissociation constants and thermodynamic properties of amino acids used in $\mathrm{CO}_{2}$ absorption from (293 to 353) K. Journal of Chemical Engineering Data 52, 2491-2502

Van Holst, J., Kersten S.R.A., Hogendoorn K.J. 2008. Physicochemical properties of several aqueous amino acid salts. Journal of Chemical Engineering Data 53, 1286-1291

Van Holst, J., Versteeg, G.F., Brilman, D.W.F., Hogendoorn, J.A., 2009. Kinetic study of $\mathrm{CO}_{2}$ with various amino acid salts in aqueous solution. Chemical Engineering Science 64, 59-68

Hook, R.J., 1997. An investigation of some sterically hindered amines as potential carbon dioxide scrubbing compounds. Industrial and Engineering Chemistry Research 36, 1779-1790

Jones, J.H., Froning, H.R., Claytor, E.E., 1959. Solubility of acid gases in aqueous monoethanolamine. Journal of Chemical Engineering Data 4, 85-91

Jou, F.Y., Mather, A.E., Otto, F.D., 1982. Solubility of $\mathrm{H}_{2} \mathrm{~S}$ and $\mathrm{CO}_{2}$ in aqueous methyldiethanolamine solutions. Industrial and Engineering Chemistry Process Design and Development 21, 539-544

Kent, R.L., Eisenberg, B., 1976. Better data for amine treating. Hydrocarbon Processing 55, 87-90

Kim, I., Svendsen, F., 2007. Heat of absorption of carbon dioxide $\left(\mathrm{CO}_{2}\right)$ in monoethanolamine (MEA) and 2-(aminoethyl)ethanolamine (AEEA) solutions. Industrial and Engineering Chemistry Research 46, 5803-5809

Kohl, A.L., Nielsen, R.B., 1997. Gas Purification: $5^{\text {th }}$ Edition. Gulf Publishing Company, Houston 
Kumar, P.S., Hogendoorn, J.A., Timmer, J.S. Feron, P.H.M., 2003. Equilibrium solubility of $\mathrm{CO}_{2}$ in aqueous potassium taurate solutions: part 2. Experimental VLE data and model. Industrial and Engineering Chemistry Research 42, 2841-2852

Lee, J.I., Otto, F.D., Mather, A.E., 1972. Solubility of carbon dioxide in aqueous diethanolamine solutions at high pressure. Journal of Chemical Engineering Data 17, 465-486

Lee, J.I., Otto, F.D., Mather, A.E., 1974. The solubility of $\mathrm{H}_{2} \mathrm{~S}$ and $\mathrm{CO}_{2}$ in aqueous monoethanolamine solutions. The Canadian Journal of Chemical Engineering 52, 803-805

Lee, J.I., Otto, F.D., Mather A.E., 1976. Equilibrium between carbon dioxide and aqueous monoethanol-amine solutions. Journal of Applied Chemistry and Biotechnology 26, 541-549

Li, M.H., Shen, K.P., 1993. Calculation of equilibrium solubility of carbon dioxide in aqueous mixtures of monoethanolamine with methyldiethanolamine. Fluid Phase Equilibria 85, 129-140

Li, M.H., Chang, B.C., 1994. Solubilities of carbon dioxide in water + monoethanolamine + 2-amino-2-methyl-1-propoanol. Journal of Chemical and Engineering Data 39, 448-452

Li, Y., Mather, A.E., 1994. Correlation and prediction of the solubility of carbon dioxide in a mixed alkanolamine solution. Industrial and Engineering Chemistry Research 33, 2006-2025

Majchrowicz, M.E., Brilman, D.W.F., Groeneveld, M.J., 2009. Precipitation regime for selected amino acid salts for $\mathrm{CO}_{2}$ capture from flue gases. Energy Procedia 1, 979-984

Ma'mun, S., Nielsen, R., Svendsen, H.F., 2005. Solubility of carbon dioxide in 30 mass\% monoethanolamine and 50 mass $\%$ methyldiethanolamine solutions. Journal of Chemical Engineering Data 50, 630-634

Mundhwa, M., Henni, A., 2007. Molar excess enthalpy $\left(\mathrm{H}_{\mathrm{m}}^{\mathrm{E}}\right)$ for various \{alkanolamine (1) + water (2) $\}$ systems at $\mathrm{T}=(298.15,313.15$, and 323.15) K. The Journal of Chemical Thermodynamics 39, 1439-1451

Oexmann, J., Kather, A., 2010. Minimising the regeneration heat duty of post-combustion $\mathrm{CO}_{2}$ capture by wet chemical absorption: The misguided focus on low heat of absorption solvents. International Journal of Greenhouse Gas Control 4, 36-43

Perrin, D.D., 1965. Dissociation of organic bases in aqueous solutions. Butterworth, London

Perry, R.H., Green, D.W., 1997. Perry's Chemical Engineers' Handbook: $7^{\text {th }}$ Edition. McGraw-Hill

Portugal, A.F., Souse, J.M., Magalhães, F.D., Mendes, A., 2009. Solubility of carbon dioxide in aqueous solutions of amino acid salts. Chemical Engineering Science 64, 1993-2002

Posey, M.L., Tapperson, K.G., Rochelle, G.T., 1996. A simple model for prediction of acid gas solubilities in alkanolamines. Gas Separation and Purification 10, 181-186 
Rochelle, G.T., Goff, G.S., Cullinane, J.T., Freguia, S., 2002. Research results for $\mathrm{CO}_{2}$ capture from flue gas by aqueous absorption/stripping. Laurance Reid Conditioning Conference, Norman, Oklahoma USA, February 25-27

Salazar, V., Sánchez-Vincente, Y., Pando, C., Renuncio, J.A.R., Cabaňas, A., 2010. Enthalpies of absorption of carbon dioxide in aqueous sodium glycinate solutions at temperatures of (313.15 and 323.15) K. Journal of Chemical Engineering Data 55, 1215-1218

Sartori, S., Savage, D.W., 1983. Sterically hindered amines for $\mathrm{CO}_{2}$ removal from gases. Industrial and Engineering Chemistry Fundamentals 22, 239-249

Seo, D.J., Hong, W.H., 1996. Solubilities of carbon dioxide in aqueous mixtures of diethanolamine and 2-amino-2-methyl-1-propanol. Journal of Chemical and Engineering Data 41, 258-26o

Shao, R., Stangeland, A., 2009. Amines used in $\mathrm{CO}_{2}$ capture - health and environmental impacts. Bellona Report

Shen, K.P, Li, M.H., 1992. Solubility of carbon dioxide in aqueous mixtures of monoethanolamine with methyldiethanolamine. Journal of Chemical and Engineering Data 37, 96-100

da Silva, E.F., Svendsen, H.F., 20o6. Study of the carbamate stability of amines using ab initio methods and free-energy perturbations. Industrial and Engineering Chemistry Research 45, 24972504

Simons, K, Nijmeijer, K., Mengers H., Brilman W., Wessling M., 2010. Highly selective amino acid salt solutions as absorption liquid for $\mathrm{CO}_{2}$ capture in gas-liquid membrane contactors. ChemSusChem 3, 939-947

Song ,J., Park, S., Yoon, J., Lee, J.I., 1996. Solubility of carbon dioxide in monoethanolamine + ethylene glycol + water and monoethanolamine + poly(ethylene glycol) + water. Journal of Chemical and Engineering Data 41, 497-499

Turlington, N.L., McKetta J.J., 1961. The compressibility of carbon dioxide and nitrous oxide at low pressures. American Institute of Chemical Engineers Journal 2, 336-337

Versteeg, G.F., van Swaaij, W.P., 1988. Solubility and diffusivity of acid gases (carbon dioxide, nitrous oxide) in aqueous alkanolamine solutions. Journal of Chemical Engineering Data 33, 29-34

Weisenberger S., Schumpe, A. 1996. Estimation of gas solubilities in salt solutions at temperatures from 273 to 363 K. American Institute of Chemical Engineers Journal 42, 298-300 

Chapter 4

\section{Reactive Absorption of Carbon Dioxide in L-Prolinate Salt Solutions}

Aqueous amino acid salt solutions are seen as more sustainable alternative $\mathrm{CO}_{2}$ solvents compared to conventional (alkanol)amines. The absorption of $\mathrm{CO}_{2}$ into aqueous solutions of potassium L-prolinate, over the temperature range of 290-303 K, was studied using a stirred cell. To compare the effect of potassium versus sodium as a counterion, the absorption rates of $\mathrm{CO}_{2}$ in sodium L-prolinate solutions was also determined. The amino acid salt concentration was varied between 0.5 and $3 \mathrm{~mol} \cdot \mathrm{dm}^{-3}$. Physico-chemical properties such as density, viscosity and physical solubility of $\mathrm{N}_{2} \mathrm{O}$, required in the interpretation of absorption rate experiments, were determined separately. The obtained experimental reactive absorption fluxes were interpreted, using the pseudo-first order approach, into intrinsic reaction kinetics. Potassium based solvent showed, on average, a $32 \%$ higher reactivity towards $\mathrm{CO}_{2}$ than the sodium equivalent. The kinetic data was correlated in a power-law reaction rate expression. The reaction order with respect to the amino acid was found to be between 1.40 and 1.44 for both L-prolinate salts, and the second order kinetic rate constant, $k_{2}$, was calculated for the potassium salt to be $93 \cdot 7 \cdot 10^{3} \mathrm{dm}^{3} \cdot \mathrm{mol}^{-1} \cdot \mathrm{s}^{-1}$ at $298 \mathrm{~K}$ with an activation energy of $43.3 \mathrm{~kJ} \cdot \mathrm{mol}^{-1}$. L-Prolinate salts show higher chemical reactivity towards $\mathrm{CO}_{2}$ than most of amino-alcohols and amino acid salts.

This chapter is an excerpt of scientific paper published as:

Majchrowicz, M.E., Brilman, D.W.F., Kersten, S.R.A, 2014. Reactive absorption of carbon dioxide in L-prolinate salt solutions. Industrial and Engineering Chemistry Research 53, 11460-11467 


\subsection{Introduction}

Absorption with chemical reaction is a common process in the chemical industry and is used, among others, in the treatment of the industrial gas streams containing acid gases like $\mathrm{H}_{2} \mathrm{~S}, \mathrm{NO}_{x}$ and $\mathrm{CO}_{2}$. In these gas treating processes, aqueous solutions of aminoalcohols (MEA, DEA, MDEA, AMP, their mixtures with or without "activators", etc.) are commonly used. The use of these compounds is, however, associated with: (i) limited cyclic $\mathrm{CO}_{2}$ capacity, (ii) high equipment corrosion rates and the necessity of the corrosion inhibitors addition,(ii) high energy requirements for solvent regeneration, (iv) solvent losses due to evaporation, thermal- and oxidative degradation (Kohl and Nielsen, 1997). In contrast to (alkanol)amines, amino acid salts (AAS) solutions are characterized by low volatility (due to their ionic nature) and higher surface tension (important for membrane gas absorption) (Kumar et al., 2001; Simons et al., 2010a), as well as by high level of biodegradability in combination with low toxicity (Shao and Stangeland, 2009). At the same time they maintain (due to similar functionality) a comparable or even higher chemical reactivity towards $\mathrm{CO}_{2}$ (Hook, 1997; Kumar et al., 2003, van Holst et al., 2009). Due to these favourable properties, amino acid salts have been deployed in the past as rate promoters in carbonate solutions in the Giammarco-Vetrocoke process and for the selective acid gas removal from industrial gas streams as, for example, in the Alkacid process by BASF (Kohl and Nielsen, 1997). In the recent years, also Siemens AG has developed a proprietary post-combustion carbon capture technology (POSTCAP) based on aqueous amino acid salt solutions.

Knowledge of the reaction kinetics between $\mathrm{CO}_{2}$ and amino acid salts is essential for accurate design and simulation of $\mathrm{CO}_{2}$ absorption process. Kumar et al. (2003) measured the reaction kinetics of $\mathrm{CO}_{2}$ in aqueous solutions of potassium taurate at temperatures of 285,295 and $305 \mathrm{~K}$ and potassium glycinate at $295 \mathrm{~K}$, and over the solution concentration ranging from 0.1 to $4 \mathrm{~mol} \cdot \mathrm{dm}^{-3}$. Potassium salt of glycine was studied also by Portugal et al. (2007) who measured the absorption rates of $\mathrm{CO}_{2}$ at temperatures from 293 to $313 \mathrm{~K}$, over the solution concentration range of $0.1-3 \mathrm{~mol} \cdot \mathrm{dm}^{-3}$. Portugal et al. (2008) determined the reaction kinetics of $\mathrm{CO}_{2}$ in potassium threoninate aqueous solution at concentration ranging from 0.1 to $3 \mathrm{~mol} \cdot \mathrm{dm}^{-3}$ and temperatures from 293 to $313 \mathrm{~K}$. Van Holst et al. (2009) related the overall kinetic constant with $\mathrm{p} K_{a}$ for several amino acid salts by means of a Brønsted plot. Potassium salts of 6-aminohaxanoic acid, $\beta$-alanine, L-arginine, L-glutamic acid, DL-methionine, L-proline and sarcosine were considered. It was argued that high reaction rate is important for reducing the size and hence capital costs of the absorber, while relatively low $\mathrm{p} K_{a}$ is of importance for minimizing the energy input in the desorber. Based on this criterion, alkaline salts of L-proline and sarcosine were identified as promising amino acid salt solvents for $\mathrm{CO}_{2}$ capture. Simons et al. (2010b) studied the absorption rate of $\mathrm{CO}_{2}$ in aqueous potassium sarcosinate solution. A change of the reaction rate constant with 
temperature $\left(T=298-308 \mathrm{~K}, C_{m}=1.5 \mathrm{M}\right)$, amino acid salt concentration $\left(T=298 \mathrm{~K}, C_{m}=0.5^{-}\right.$ $3.8 \mathrm{M}$ ) and $\mathrm{CO}_{2}$ liquid loading ( $\alpha=0-0.5$ mole $\mathrm{CO}_{2}$ per mole solvent, $T=298 \mathrm{~K}, C_{m}=1.45 \mathrm{M}$ ) was reported. Paul and Thomsen (2012) studied the absorption rate of $\mathrm{CO}_{2}$ in aqueous potassium L-prolinate solution at 303, 313 and $323 \mathrm{~K}$ within the salt concentration range of $0.5-3 \mathrm{~mol} \cdot \mathrm{dm}^{-3}$.

In the present work, the absorption of $\mathrm{CO}_{2}$ into aqueous solutions of potassium L-prolinate was studied using a stirred cell apparatus and over the temperature range of 290-303 K. The absorption rates of $\mathrm{CO}_{2}$ were also measured for the sodium salt at $298 \mathrm{~K}$. The amino acid salt concentration varied between 0.5 and $3 \mathrm{~mol} \cdot \mathrm{dm}^{-3}$. After validating that the absorption experiments were conducted in the so-called pseudo first order regime, the reaction rate constants between L-prolinate salts and $\mathrm{CO}_{2}$ were extracted from the obtained experimental data using this approach. Complementary to the kinetic data, the physico-chemical properties such as density, viscosity and physical solubility of $\mathrm{N}_{2} \mathrm{O}$ in L-prolinate salts were determined. These data are reported in the Appendix.

Liquid bulk concentrations of all chemical species are required for the kinetic analysis. The vapour-liquid equilibrium model to estimate the partial pressure of $\mathrm{CO}_{2}$ and liquid bulk concentrations of all chemical species present in the solution was earlier described by Majchrowicz and Brilman (2012). Using the experimental data from the present work, this model could be further extended to a comprehensive absorption rate/kinetics model for interpreting the absorption data of $\mathrm{CO}_{2}$ in aqueous amino acid salt solutions.

\subsection{Reaction mechanism}

In aqueous solutions, $\mathrm{CO}_{2}$ reacts with an alkaline salt of (primary or secondary) amino acid to the corresponding carbamate according to the overall reaction 4.1 (here ' $\mathrm{RNH}$ ' corresponds to L-prolinate with a non-reacting part $\mathrm{R} \equiv \mathrm{C}_{4} \mathrm{H}_{7}-\mathrm{COO}^{-}$).

$$
2 \mathrm{RNH}+\mathrm{CO}_{2} \rightleftharpoons \mathrm{RNH}_{2}^{+}+\mathrm{RNCOO}^{-}
$$

The zwitterion mechanism, originally proposed by Caplow (1968), is generally applied to model $\mathrm{CO}_{2}$ absorption in aqueous solutions of amino-alcohols or amino acid salts. This reaction mechanism involves the formation of an intermediate, a 'zwitterion' (Equation 4.2), followed by the removal of a proton by a base, $B$ (Equation 4.3 ). The deprotonation reaction can be considered to be irreversible (equilibrium predominantly to the right hand side of the reaction). 


$$
\begin{gathered}
\mathrm{CO}_{2}+\mathrm{RNH} \underset{k_{-1}}{\stackrel{k_{2}}{\rightleftarrows}} \mathrm{RNH}^{+} \mathrm{COO}^{-} \\
\mathrm{RNH}^{+} \mathrm{COO}^{-}+\mathrm{B} \stackrel{k_{B}}{\rightarrow} \mathrm{RNCOO}^{-}+\mathrm{BH}^{+}
\end{gathered}
$$

Assuming a quasi-stead state condition for the zwitterion concentration and a first order behaviour of $\mathrm{CO}_{2}$, the overall forward rate of reaction of $\mathrm{CO}_{2}$ with amino acid salt can be expressed with Equation 4.4 (Danckwerts, 1979).

$$
r_{\mathrm{CO}_{2}}=\frac{k_{2}[\mathrm{RNH}]\left[\mathrm{CO}_{2}\right]}{1+\frac{k_{-1}}{\sum k_{B}[B]}}=\frac{[\mathrm{RNH}]\left[\mathrm{CO}_{2}\right]}{\frac{1}{k_{2}}+\frac{k_{-1}}{k_{2}} \frac{1}{\sum k_{B}[B]}}=k_{\text {app }}\left[\mathrm{CO}_{2}\right]
$$

where $\sum k_{B}[B]$ designates the contribution of all bases present in the solution for the proton removal step. In lean aqueous solutions, the liquid phase reactant, $\mathrm{H}_{2} \mathrm{O}$ and $\mathrm{OH}^{-}$species can act as bases (Blauwhoff et al., 1984).

Limiting conditions will lead to more simplified reaction rate expressions (Kumar et al., 2003). If the deprotonation of the zwitterion is relatively fast compared to the reversion rate of $\mathrm{CO}_{2}$ and amine, hence $k_{-1} / \sum k_{b}[B] \ll 1$, the kinetic rate expression reduces to simple second order kinetics as found for primary alkanolamines such as MEA - see Equation 4.5. If, on the other hand, $k_{-1} / \sum k_{b}[B] \gg 1$ then the kinetic rate expression reduces to Equation 4.6. In this case the reaction order depends on a contribution of the individual bases to deprotonation of the zwitterion. This expression accounts as well for the reaction order shift with changing amine concentration as found for many secondary alkanolamines (Versteeg et al., 1996). Both asymptotic options seem plausible for alkaline salts of L-proline. Similarly to DEA, this amino acid has a secondary amino functional group. On the other hand, L-prolinate has higher $\mathrm{p} K_{a}$ value than MEA, which should result in high deprotonation rate constant, $k_{B}$.

$$
\begin{gathered}
r_{\mathrm{CO}_{2}}=k_{2}\left[\mathrm{CO}_{2}\right][R N H] \\
r_{\mathrm{CO}_{2}}=k_{2}\left[\mathrm{CO}_{2}\right][R N H]\left(\frac{\sum k_{B}[B]}{k_{-1}}\right)
\end{gathered}
$$

Besides the carbamate formation from amino acid salt by reaction 4.2, other reactions can occur in $\mathrm{CO}_{2}-\mathrm{AAS}-\mathrm{H}_{2} \mathrm{O}$ systems.

$$
\mathrm{CO}_{2}+\mathrm{OH}^{-} \stackrel{k_{O H^{-}}}{\longrightarrow} \mathrm{HCO}_{3}^{-}
$$




$$
\mathrm{CO}_{2}+\mathrm{H}_{2} \mathrm{O} \stackrel{k_{\mathrm{H}_{2} \mathrm{O}}}{\longrightarrow} \mathrm{HCO}_{3}^{-}+\mathrm{H}^{+}
$$

For amino acid salts, the contribution of reactions 4.7 and 4.8 to the overall rate of $\mathrm{CO}_{2}$ absorption is usually neglected (Kumar et al., 2003, van Holst et al., 2009; Portugal et al., 2007, 2008). If the reaction between $\mathrm{CO}_{2}$ and $\mathrm{OH}^{-}$ions is taken into account then the overall reaction kinetic constant can be expressed by Equation 4.9, where $k_{a p p}$ is the apparent rate constant for reaction 4.7. The concentration of $\mathrm{OH}^{-}$is obtained by the $\mathrm{pH}$ measurements. The rate constant $k_{\mathrm{OH}^{-}}$is correlated to temperature and ionic strength by Equations 4.10 and 4.11 (Pohorecki and Moniuk, 1988).

$$
\begin{gathered}
k_{o v}=k_{a p p}+k_{O H^{-}}\left[\mathrm{OH}^{-}\right] \\
\log \frac{k_{O H^{-}}}{k_{O H^{-}}^{\infty}}=a I-b I^{2} \\
\log k_{O H^{-}}^{\infty}=11.895-\frac{2382}{T}
\end{gathered}
$$

Here, $k_{O H^{-}}^{\infty}$ is the rate constant of reaction 4.7 in an infinitely diluted solution, $I$ is the solution ionic strength, and constants $a, b$ for different counterions are given in Table 4.1.

Table 4.1: Constants in Equation 4.10 (Pohorecki and Moniuk, 1988)

\begin{tabular}{lcc}
\hline System & $a$ & $b$ \\
\hline $\mathrm{CO}_{2}-\mathrm{KOH}$ & 0.287 & 0.013 \\
$\mathrm{CO}_{2}-\mathrm{NaOH}$ & 0.211 & 0.016 \\
\hline
\end{tabular}

\subsection{Mass transfer}

Generally, the absorption rate of $\mathrm{CO}_{2}$ in a reactive liquid, in the absence of gas phase limitations and assuming the ideal gas behaviour under low pressures applied in the experiments, is given by (Danckwerts, 1970; Derks et al., 2006):

$$
J_{\mathrm{CO}_{2}}=k_{\mathrm{L}} E_{\mathrm{CO}_{2}} \frac{m_{\mathrm{CO}_{2}} p_{\mathrm{CO}_{2}}}{R T}
$$

where $J_{\mathrm{CO}_{2}}$ is the molar flow of $\mathrm{CO}_{2}$ entering the liquid, $k_{\mathrm{L}}$ is the liquid-side mass transfer coefficient, $p_{\mathrm{CO}_{2}}$ is partial pressure of $\mathrm{CO}_{2}$ in the reactor, $m_{\mathrm{CO}_{2}}$ is the distribution coefficient of $\mathrm{CO}_{2}$ between the gas and liquid phases, and $\mathrm{E}_{\mathrm{CO}_{2}}$ is the enhancement factor. The parameter $m_{\mathrm{CO}_{2}}$ describes the physical solubility of $\mathrm{CO}_{2}$ in the solution and equals to $(R \cdot T)$ 
divided by the Henry coefficient, $\mathrm{He}$. It is defined by $m_{\mathrm{CO}_{2}}=C_{l, i} / C_{g, i}$, in which $C_{g, i}$ equals to molar concentration of $\mathrm{CO}_{2}$ in the gas phase and $C_{l, I}$ is the corresponding physical solubility of $\mathrm{CO}_{2}$ in the liquid phase. The enhancement factor is a ratio of the chemical absorption flux to the absorption flux in the absence of a chemical reaction. The enhancement factor is a function of the Hatta number, $H a$, and is limited by the infinite enhancement factor, $E_{\infty}$. The Hatta number is defined by Equation 4.13 and relates the maximum conversion rate within the mass transfer zone to the diffusional transport through the mass transfer zone (Hikita and Asai, 1976). The infinite enhancement factor is determined by the diffusion of reactants towards the reaction zone and thus corresponds to an instantaneous reaction. Its value can be estimated, according to the penetration theory, by Equation 4.14 (Higbie, 1935). It should be noted, however, that this equation is valid only for irreversible reactions. In the present work, due to a high value for the equilibrium constant of reaction 4.1 (Majchrowicz and Brilman, 2012) and negligible liquid $\mathrm{CO}_{2}$ loadings present in the experiments, this reaction is regarded as essentially irreversible.

$$
\begin{gathered}
H a=\frac{\sqrt{k_{o v} D_{C O_{2}}}}{k_{L}} \\
E_{\infty}=\sqrt{\frac{D_{C O_{2}}}{D_{A A S}}} \cdot\left(1+\frac{D_{A A S}}{D_{C O_{2}}} \cdot \frac{[A A S] R T}{v_{A A S} P_{C O_{2}} m_{C O_{2}}}\right)
\end{gathered}
$$

In the above equations, $k_{o v}$ is the overall reaction kinetic constant, $D_{\mathrm{CO}_{2}}$ is the diffusion coefficient of $\mathrm{CO}_{2}$ in a solution, $D_{A A S}$ is the diffusion coefficient of the liquid phase reactant in a solution, and $v_{A A S}$ is the stoichiometric coefficient that in analogy to alkanolamines has a value of 2 (Park et al., 2007; Vučak et al., 2002, Simons et al., 2010b).

Three absorption regimes can be distinguished depending on the absolute value of the Hatta number and the $\mathrm{Ha} / \mathrm{E}_{\infty}$ ratio (Danckwerts, 1970; Derks et al., 2006, Portugal et al, 2007, 2008). Absorption taking place in the fast pseudo-first-order reaction regime can be assumed if the following condition is satisfied:

$$
3<E=H a \ll \mathrm{E}_{\infty}
$$

In this absorption regime, the enhancement factor equals the Hatta number, which makes it possible to obtain the kinetics for the forward reaction, starting with unloaded solutions. Consequently, Equation 4.12 changes to:

$$
J_{\mathrm{CO}_{2}}=\sqrt{k_{\mathrm{Ov} D_{\mathrm{CO}_{2}}}} \frac{m_{\mathrm{CO}_{2}} p_{\mathrm{CO}_{2}}}{R T}
$$


The instantaneous reaction regime refers to conditions for which $E_{\infty} \ll H a$. In this regime, the reaction is said to be instantaneous with respect to mass transfer and determination of the reaction kinetics from the absorption rate experiments is not possible. In between above two reaction regimes, there is an 'intermediate regime' for which the enhancement factor can be approximated as a function of $H a$ and $E_{\infty}$ (DeCoursey, 1974; van Swaaij and Versteeg, 1992).

Physico-chemical properties such as physical solubility of $\mathrm{CO}_{2}$ and diffusion coefficients are needed to obtain the kinetic rate coefficient estimates. Since $\mathrm{CO}_{2}$ reacts with amino acid salts, the physical solubility of $\mathrm{CO}_{2}$ in these solvents is not measurable and needs to be estimated indirectly from the solubility experiments with $\mathrm{N}_{2} \mathrm{O}$. This non-reactive gas is widely used for this purpose because it has a molecular configuration, volume and electronic structure similar to that of $\mathrm{CO}_{2}$ (Laddha et al., 1981). Additionally, for gas solubility in aqueous L-prolinate solutions, the model proposed by Weisenberger and Schumpe (1996) for electrolyte solutions was applied to correlate the salting out effect.

$$
\log \left(\frac{m_{\mathrm{H}_{2} \mathrm{O}}}{m}\right)=K C_{m}
$$

Here $m_{\mathrm{H}_{2} \mathrm{O}}$ and $m$ denotes gas solubility in pure water and in the salt solution, respectively, $C_{m}$ is molar concentration of the salt. For a single salt, the Sechenov constant, $K$, is then given by the following relation:

$$
K=\sum\left(h_{i}+h_{g}\right) n_{i}
$$

with

$$
h_{g}=h_{g, 0}+h_{T}(T-298.15 \mathrm{~K})
$$

Here $h_{i}$ and $h_{g}$ are the ion and gas specific parameters, respectively, and $n_{i}$ is the index of ion $i$.

The gas-specific parameters, $h_{g}$, and the ion-specific constants, $h_{i}$, (of ions other than L-prolinate) were obtained from Weisenberger and Schumpe (1996). The L-prolinate ionspecific parameter was obtained (as a function of temperature) from the measured $\mathrm{N}_{2} \mathrm{O}$ solubility in this solvent, see Appendix. The distribution coefficient of $\mathrm{CO}_{2}$ and $\mathrm{N}_{2} \mathrm{O}$ in water were obtained from Versteeg and van Swaaij (1988). The diffusivity of $\mathrm{N}_{2} \mathrm{O}$ in the absorption liquids, $D_{\mathrm{N}_{2} \mathrm{O}}$, was calculated using the Stokes-Einstein relation:

$$
\frac{D_{N_{2} O}}{D_{N_{2} O H_{2} O}}=\left(\frac{\mu_{H_{2} O} O}{\mu}\right)^{\propto}=\text { constant }
$$


where usually $0.5<\alpha<1$. The $\mathrm{N}_{2} \mathrm{O}-\mathrm{CO}_{2}$ analogy was further used to estimate the diffusivity of $\mathrm{CO}_{2}$ in L-prolinate solutions (Gubbins et al., 1966). The $\alpha$ value of o.6 was used to estimate the diffusion coefficient of $\mathrm{N}_{2} \mathrm{O}$ in aqueous solutions of L-prolinate (Paul and Thomsen, 2012). This value was used also for MEA (Portugal et al., 2007). For potassium salts of L-proline, viscosities, $\mu$, reported by van Holst et al. (2008) were used. For the sodium salts, viscosities obtained in the present work and reported in the Appendix were applied. The viscosities of water, $\mu_{\mathrm{H}_{2} \mathrm{O}}$, were taken from Popiel and Wojtkowiak (1998). The diffusivity of $\mathrm{CO}_{2}$ and $\mathrm{N}_{2} \mathrm{O}$ in water were obtained from Versteeg and van Swaaij (1988). The diffusion coefficients of L-prolinate in aqueous solution, as required in Equation 4.14, were taken from work by Hamborg et al. (2008).

\subsection{Experimental section}

The $\mathrm{CO}_{2}$ [124-38-9] gas used was obtained from Linde Gas. L-proline ((S)pyrrolidine-2-carboxylic acid, $\mathrm{C}_{5} \mathrm{H}_{9} \mathrm{NO}_{2}, \geq 98.5 \%$ ) [147-85-3], $\mathrm{KOH}(\geq 85.0 \%$; with the actual purity determined accurately by titration) [1310-58-3], $\mathrm{NaOH}(\geq 98.0 \%)$ [1310-65-2], MEA (2-aminoethanol, $\mathrm{C}_{2} \mathrm{H}_{7} \mathrm{NO}, \geq 99.0 \%$ ) [141-43-5] were purchased from Sigma-Aldrich and were used without further purification. Aqueous L-prolinate solutions were prepared by neutralizing the amino acid dissolved in deionized, double-distilled water with an equimolar quantity of an alkaline hydroxide. The amino acid salt concentration was estimated potentiometrically by titrating with a standard $1.000 \mathrm{~mol} \cdot \mathrm{dm}^{-3} \mathrm{HCl}$ solution [7647-01-o].

A schematic representation of the gas-liquid contactor used to study the reaction kinetics is given in Figure 4.1 and is identical to the one used by Simons et al. (2010b). The experimental set-up consisted essentially of the thermostatted cell operated with a smooth, horizontal gas-liquid interface and a calibrated gas supply vessel. Two separate stirrers were used in the reactor to agitate the gas and liquid phases. The reactor was operated batch-wise with respect to the liquid phase and 'semi-continuous' with respect to the gas phase. To allow for this mode of operation, the reactor was connected to the gas supply vessel via a constant-pressure regulator. In a typical experiment, a known amount of a solvent solution $\left(\cong 0.60 \mathrm{dm}^{3}\right)$ was charged to the reactor and shortly degassed under vacuum. After that, the vapour-liquid equilibrium was allowed to establish in the reactor at the desired temperature. This was repeated until pressure did not change anymore and the vapour pressure of a solvent was reached. This pressure was recorded as the vapour pressure, $P_{\text {vap }}$. The pressure controller was set to the desired (total) pressure, $P_{t o t}$, and pure $\mathrm{CO}_{2}$ from the gas supply vessel was introduced into the reactor. Next, the stirrers in both phases were turned on and pressure in the gas supply vessel was monitored for around $300 \mathrm{~s}$. The 
dynamic pressure in the gas vessel $\left(d P_{g v} / d t\right)$ was recorded with a pressure transducer connected to a computer. The pressure in the reactor was also continuously recorded, with an accuracy of 0.07 mbar, to verify whether the $\mathrm{CO}_{2}$ partial pressure $\left(P_{\mathrm{CO}_{2}}=P_{\text {tot }}-P_{v a p}\right)$ remained constant. The pressure decrease in the gas vessel was due to $\mathrm{CO}_{2}$ absorption in the liquid and can be related to the kinetics by Equation 4.22; if the experiments are carried out in the pseudo-first order absorption regime.

$$
J_{\mathrm{CO}_{2}} A=\frac{d P_{g v}}{d t} \cdot \frac{V_{g v}}{R T_{g v}}
$$

Here $A$ is the geometric gas-liquid interfacial area, $V_{g v}$ is volume and $T_{g v}$ is temperature of the gas vessel, respectively. In this reaction regime, the $\mathrm{CO}_{2}$ absorption rate is independent of the liquid side mass transfer coefficient and the generic $\mathrm{CO}_{2}$ absorption rate $\left(\mathrm{JOO}_{2} A\right)$ is given as (Kumar et al., 2003; Simons et al., 2010b):

$$
J_{\mathrm{CO}_{2}} A=\left(\sqrt{k_{\mathrm{Ov} D_{\mathrm{CO}_{2}}}}\right) m_{\mathrm{CO}_{2}}\left(\frac{P_{\mathrm{CO}_{2}}}{R T}\right) A
$$

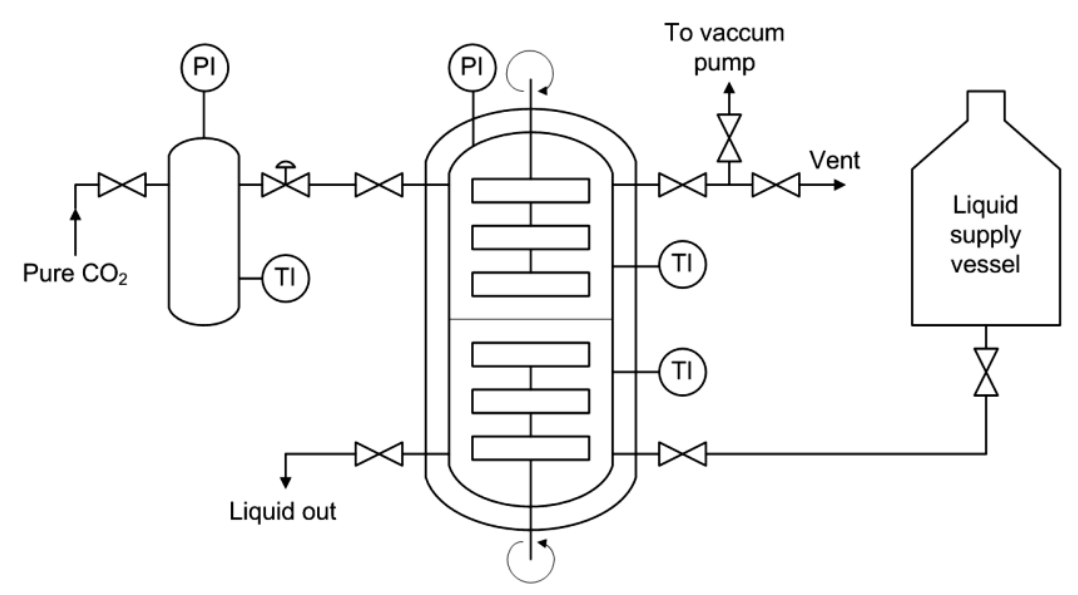

Figure 4.1: Schematic diagram of the experimental set-up used to determine the reaction kinetics

\subsection{Results and discussion}

The physico-chemical properties required in the interpretation of absorption rate experiments for alkaline salts of L-proline can be found in the Appendix. 
For validation of the experimental setup and procedures followed, the absorption rate of $\mathrm{CO}_{2}$ in aqueous $2 \mathrm{~mol} \cdot \mathrm{dm}^{-3}$ solutions of MEA at 288, 298 and $303 \mathrm{~K}$ was measured. Table 4.2 compares the observed $k_{2}$ values with those obtained using the rate constant expression given by Versteeg et al. (1996), $k_{2}=4.4 \times 10^{8} \exp (-5400 / T)$, and are considered to be in good agreement.

Table 4.2: Reaction between $\mathrm{CO}_{2}$ and aqueous MEA

\begin{tabular}{lccc}
\hline & \multicolumn{3}{c}{$k_{2}\left[\mathrm{dm}^{3} \cdot \mathrm{mol}^{-1} \cdot \mathrm{s}^{-1}\right]$} \\
\cline { 2 - 4 }$[\mathrm{K}]$ & 288 & 298 & 303 \\
\hline this study & $3.20 \times 10^{3}$ & $5.57 \times 10^{3}$ & $8.71 \times 10^{3}$ \\
Versteeg et al. (1996) & $3.20 \times 10^{3}$ & $5.92 \times 10^{3}$ & $8.23 \times 10^{3}$ \\
\hline
\end{tabular}

The absorption rate of $\mathrm{CO}_{2}$ in aqueous solutions of potassium L-prolinate was investigated at temperatures of 290, 298 and $303 \mathrm{~K}$ and over the solution concentration range of 0.5 to $3 \mathrm{~mol} \cdot \mathrm{dm}^{-3}$. The reaction kinetics of $\mathrm{CO}_{2}$ in sodium L-prolinate was also determined from the absorption experiments at $298 \mathrm{~K}$ for the same solution concentration range. In the determination of the kinetic rates, only the data at sufficiently low $\mathrm{CO}_{2}$ partial pressures, where a linear relation exists between the experimentally observed flux and $\mathrm{CO}_{2}$ partial pressure (hence, where ' $E=H a$ ') were used; as this constant slope indicates the pseudo-first order behaviour. The results of the kinetic experiments are presented in Tables 4.3 and 4.4 for the potassium and sodium salts, respectively. For both salts of L-proline the condition described by Equation 4.15 is satisfied and the ratio between the infinite enhancement factor and the Hatta number is about a factor of four and higher. In all kinetic measurements, values of the liquid $\mathrm{CO}_{2}$ loading, $\alpha$, (in mole $\mathrm{CO}_{2}$ per mole solvent) at the end of the experiments were always lower than $5 \times 10^{-3}$. This should assure no precipitation in the considered absorption systems and no significant decrease of the free amine concentration during the experiment due to $\mathrm{CO}_{2}$ absorption (Majchrowicz et al., 2009; Majchrowicz and Brilman, 2012). Also, the contribution of $k_{\mathrm{OH}^{-}}\left[\mathrm{OH}^{-}\right]$to $k_{o v}$ is relatively small, with the maximum deviation of $5.7 \%$ for all experiments carried out and in most cases less than $1 \%$. This limited effect of $\mathrm{OH}^{-}$ions to $k_{o v}$ has been reported also for the most common weakly basic amines like MEA, DEA, glycine, taurine, sarcosine. 
Table 4.3: Kinetic data for the reaction of $\mathrm{CO}_{2}$ with potassium L-prolinate at 290,298 and $303 \mathrm{~K}$

\begin{tabular}{cccccccc}
\hline $\begin{array}{c}T \\
{[\mathrm{~K}]}\end{array}$ & $\begin{array}{c}C_{m} \\
{[\mathrm{M}]}\end{array}$ & $\begin{array}{c}p_{\mathrm{CO}_{2}} \\
{[\mathrm{mbar}]}\end{array}$ & $\begin{array}{c}J_{\mathrm{CO}_{2}} \times 10^{-4} \\
{\left[\mathrm{~mol} \cdot \mathrm{m}^{-2} \cdot \mathrm{s}^{-1}\right]}\end{array}$ & $\begin{array}{c}\mathrm{Ha} \\
{[-]}\end{array}$ & $\begin{array}{c}E_{\infty} \\
{[-]}\end{array}$ & $\begin{array}{c}k_{o v} \\
{\left[\mathrm{~s}^{-1}\right]}\end{array}$ & $\begin{array}{c}J_{\mathrm{CO}_{2}}^{*} \times 10^{-4} \\
{\left[\mathrm{~mol} \cdot \mathrm{m}^{-2} \cdot \mathrm{s}^{-1}\right]}\end{array}$ \\
\hline 290 & 0.49 & 6.62 & 5.28 & 222 & 925 & 6167 & 6.30 \\
& 1.01 & 5.86 & 7.86 & 240 & 2485 & 17481 & 7.38 \\
& 2.96 & 5.38 & 7.99 & 486 & 13455 & 80303 & 7.79 \\
298 & 0.49 & 8.07 & 8.05 & 251 & 909 & 8397 & 8.24 \\
& 1.02 & 6.07 & 8.80 & 397 & 2770 & 22395 & 8.72 \\
& 2.00 & 5.24 & 8.67 & 541 & 8535 & 57834 & 8.75 \\
& 2.94 & 8.83 & 14.02 & 609 & 9473 & 104566 & 13.81 \\
& 0.50 & 5.24 & 5.72 & 304 & 1551 & 10791 & 5.78 \\
& 1.01 & 5.93 & 9.10 & 460 & 3040 & 26424 & 9.11 \\
& 1.96 & 5.74 & 10.39 & 629 & 7895 & 67645 & 10.49 \\
& 2.98 & 6.56 & 12.30 & 758 & 13281 & 144113 & 11.24 \\
\hline
\end{tabular}

The parameter $J_{\mathrm{CO}_{2}}^{*}$ was calculated using Equations 4.24 to 4.26

Table 4.4: Kinetic data for the reaction of $\mathrm{CO}_{2}$ with sodium L-prolinate at $298 \mathrm{~K}$

\begin{tabular}{cccccc}
\hline $\begin{array}{c}C_{m} \\
{[\mathrm{M}]}\end{array}$ & $\begin{array}{c}p_{\mathrm{CO}_{2}} \\
{[\mathrm{mbar}]}\end{array}$ & $\begin{array}{c}J_{\mathrm{CO}_{2}} \times 10^{-4} \\
{\left[\mathrm{~mol} \cdot \mathrm{m}^{-2} \cdot \mathrm{s}^{-1}\right]}\end{array}$ & $\begin{array}{c}\mathrm{Ha} \\
{[-]}\end{array}$ & $\begin{array}{c}E_{\infty} \\
{[-]}\end{array}$ & $\begin{array}{c}k_{o v} \\
{\left[\mathrm{~s}^{-1}\right]}\end{array}$ \\
\hline 0.51 & 7.79 & 6.52 & 222 & 998 & 6288 \\
0.89 & 6.45 & 6.89 & 288 & 2335 & 12467 \\
1.99 & 7.00 & 8.76 & 406 & 6943 & 39572 \\
3.04 & 7.47 & 8.34 & 433 & 13964 & 76456 \\
\hline
\end{tabular}

Figure 4.2 compares the overall rate constants of potassium L-prolinate with other amino acid salts, MEA, DEA and piperazine at $298 \mathrm{~K}$. For taurine, the kinetic data are reported at $295 \mathrm{~K}$. Generally, the (secondary) ring-structure amines such as L-proline and piperazine absorb $\mathrm{CO}_{2}$ at considerable rates. Among amino acid salts, the reaction kinetics is the lowest for threoninate and taurate, and is similar to that of MEA, whereas L-prolinate shows comparable (high) reactivity towards $\mathrm{CO}_{2}$ to sarcosinate and glycinate. Lower absorption rates found for threoninate can be explained by the steric hindrance caused by the hydroxyethylene group connected to the $\alpha$ carbon (Portugal et al., 2008). 


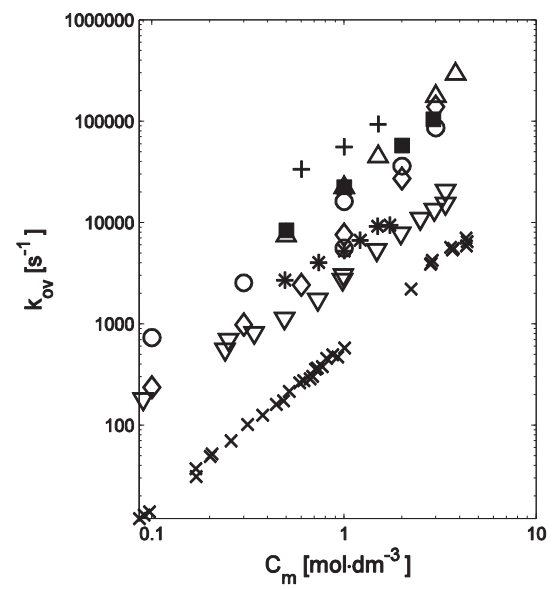

Figure 4.2: Overall kinetic constant for potassium L-prolinate compared to other $\mathrm{CO}_{2}$ absorbents at 298 K. I, potassium L-prolinate this work; $\Delta$, potassium sarcosinate Simons et al. (2010b); O, potassium glycinate Portugal et al. (2007); $\diamond$, potassium threoninate Portugal et al. (2008); $\nabla$, potassium taurate Kumar et al. (2003); +, piperazine Derks et al. (2006); *, MEA Laddha and Danckwerts (1981); ×, DEA Versteeg and Oyevaar (1989)

Figure 4.3 shows the apparent rate constants of potassium L-prolinate for 290,298 and $303 \mathrm{~K}$. For the three temperatures studied, a clear temperature dependence of $k_{\text {app }}$ can be observed. In Figure 4.4 the apparent rate constants of potassium salt of L-proline are plotted together with the $k_{a p p}$ data obtained for the sodium salt at $298 \mathrm{~K}$. A 'log-log plot' of the apparent rate constant versus the $\mathrm{CO}_{2}$ absorbent concentration is generally used to identify the mechanism of the reaction between amine and $\mathrm{CO}_{2}$. The reaction order, $n$, with respect to amine is given by the slope of the graph. For L-prolinate, this yields the $n$ value of 1.40-1.44 for the potassium and sodium salts. Paul and Thomsen (2012) investigated the reaction kinetics of potassium L-prolinate over the temperature range of 303-323 K using a wetted wall column absorber and reported the reaction order in amino acid to be in the range of 1.36-1.40. Their kinetic data reported for $303 \mathrm{~K}$ are included in Figure 4.3. In a screening study, van Holst et al. (2009) studied the kinetics of $\mathrm{CO}_{2}$-aqueous potassium L-prolinate system at $298 \mathrm{~K}$ in a stirred cell reactor using apparatus similar to that used in the present work. They gave the reaction rate expression with the reaction order in the amino acid of 1.10. The $k_{\text {app }}$ values for temperature of $298 \mathrm{~K}$ obtained by this correlation are also plotted in Figure 4.3. Whereas the data reported by Paul and Thomsen (2012) agree very well with our results, the estimates of van Holst et al. (2009) diverge from our data by $+20.5 \%$ for $0.5 \mathrm{~mol} \cdot \mathrm{dm}^{-3}$ solution and by $-30.5 \%$ for the highest solution concentration. It should be noted, however, that van Holst et al. (2009) already reported a standard deviation of $\pm 36.0 \%$ between their experimental and calculated values of $k_{\text {app }}$. The obtained fractional 
reaction orders $(n=1.40-1.44)$ have also been observed for reactions between $\mathrm{CO}_{2}$ and secondary (alkanol)amines (Danckwerts, 1979; Versteeg and Oyevaar, 1989; Versteeg et al., 1996). Alkaline salts of L-proline also contain a secondary amino group which in this respect exhibits the same behaviour.

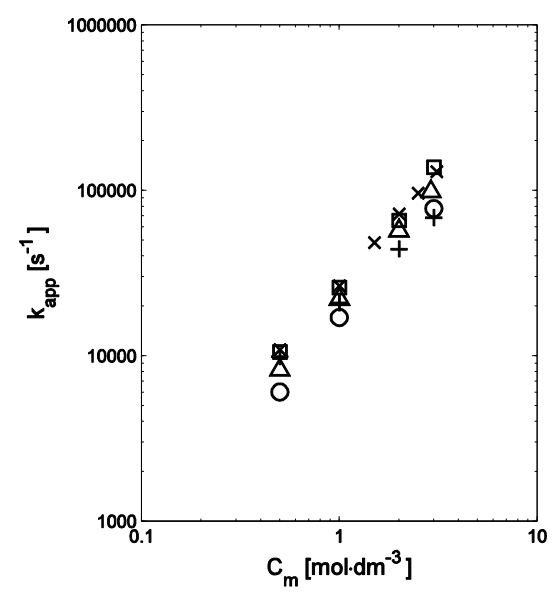

Figure 4.3: Apparent kinetic constant of potassium L-prolinate as a function of temperature and solution concentration. This work: $\mathrm{O}, T=290 \mathrm{~K} ; \Delta, T=298 \mathrm{~K} ; \square, T=303 \mathrm{~K} ;+, T=298 \mathrm{~K}$ van Holst et al. (2009); $\times, T=303 \mathrm{~K}$ Paul et al. (2012)

Pohorecki and Moniuk (1988) showed that for the reaction between $\mathrm{CO}_{2}$ and hydroxyl ions in electrolyte solutions the kinetic rate constant depends not only on the reactants concentration but also on the type of ions present in a solution. Assuming first order in the hydroxyl ion and $\mathrm{CO}_{2}$, the kinetic rate constant was found to vary significantly with the ionic strength. From their data, the reaction in potassium hydroxide solutions was around $30 \%$ faster at $1.5 \mathrm{M}$ and $80 \%$ faster in $3 \mathrm{M}$ solutions when compared to sodium hydroxide solutions at the same molar concentrations. In this study, for L-prolinate salts, the overall reaction rate also shows dependence on the type of a counterion present in a solution - see Figure 4.4. The reaction order, $n$, with respect to the prolinate ion concentration is the same for both types of solution ( $n$ is around 1.4). With this, the overall kinetic rate constant, $k_{o v}$, for potassium L-prolinate is, on average, $32 \%$ higher when compared to the sodium salt and, from the limited set of data, now independent of the L-prolinate concentration. Similarly to hydroxide solutions, the use of the activity-based kinetic rate expressions, rather than the traditional concentration-based approach, might further explain the difference in the rate constants observed (Haubrock et al., 2007). To realize this, however, the individual activity coefficients for each of the reaction components of interest would need to be determined, which is beyond the current scope. 


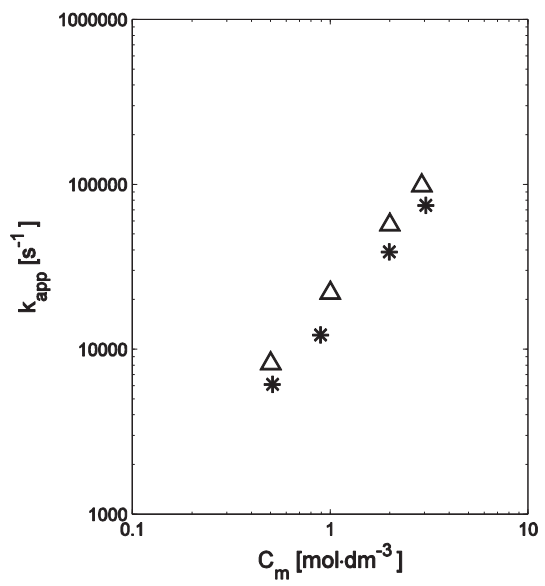

Figure 4.4: Apparent kinetic constant of alkaline salts of L-proline at $298 \mathrm{~K} . \Delta$, potassium salt; *, sodium salt

There are two limiting cases in the zwitterion mechanism. When the zwitterion formation reaction is rate limiting, the reaction rate appears to be first order in both the amine and $\mathrm{CO}_{2}$ concentrations. In the case of MEA, a primary alkanolamine, formation of the zwitterion has been shown to be the rate-determining step (Danckwerts, 1979; Versteeg and van Swaaij, 1988). On the other hand, when the zwitterion deprotonation reactions are rate determining, the overall reaction rate appears to have a fractional order between 1 and 2 in the amine concentration, as was observed in the present study. The $k_{\text {app }}$ data from the present work for potassium and sodium salts of L-proline were regressed to the reaction rate expression, Equation 4.4, by means of a Levenberg-Marquardt fitting procedure. As earlier indicated, the contribution of $\mathrm{OH}^{-}$ions to deprotonation of the zwitterion was not significant and was therefore left out from Equation 4.4. The fitted zwitterion rate coefficients are listed in Table 4.5. For potassium L-prolinate and at the system temperature of $303 \mathrm{~K}$, the second order rate constant, $k_{2}$, from the present work is in good agreement ( $4.8 \%$ higher), compared to the value given by Paul and Thomsen $(2012)\left(k_{2}=11.89 \times 10^{4}\right.$ $\left.\mathrm{dm}^{3} \cdot \mathrm{mol}^{-1} \cdot \mathrm{s}^{-1}\right)$.

Table 4.5: Zwitterion rate coefficients estimates

\begin{tabular}{lcccc}
\hline Solvent & $\begin{array}{c}\mathrm{k} \\
{[\mathrm{K}]}\end{array}$ & $\begin{array}{c}k_{2} \\
{\left[\mathrm{dm}^{3} \cdot \mathrm{mol}^{-1} \cdot \mathrm{s}^{-1}\right]}\end{array}$ & $\begin{array}{c}k_{A A S} / k_{-1} \\
{\left[\mathrm{dm}^{3} \cdot \mathrm{mol}^{-1}\right]}\end{array}$ & $\begin{array}{c}k_{\mathrm{H}_{2} \mathrm{O}} / k_{-1} \\
{\left[\mathrm{dm}^{3} \cdot \mathrm{mol}^{-1}\right]}\end{array}$ \\
\hline Potassium L -prolinate & 290 & $5.78 \times 10^{4}$ & $2.19 \times 10^{-1}$ & $3.30 \times 10^{-3}$ \\
& 298 & $9.37 \times 10^{4}$ & $1.62 \times 10^{-1}$ & $2.73 \times 10^{-3}$ \\
Sodium L -prolinate & 303 & $12.50 \times 10^{4}$ & $1.44 \times 10^{-1}$ & $2.53 \times 10^{-3}$ \\
& 298 & $8.06 \times 10^{4}$ & $1.26 \times 10^{-1}$ & $2.04 \times 10^{-3}$ \\
\hline
\end{tabular}


The rate coefficient estimates for potassium salt of L-proline were fitted as a function of temperature by the following Arrhenius equations:

$$
\begin{aligned}
& k_{2}=3.69 \times 10^{12} \exp \left(-\frac{43330}{R T}\right) \\
& \frac{k_{A A S}}{k_{-1}}=8.78 \times 10^{-6} \exp \left(\frac{24400}{R T}\right) \\
& \frac{k_{H_{2} O}}{k_{-1}}=8.65 \times 10^{-6} \exp \left(\frac{14320}{R T}\right)
\end{aligned}
$$

The average deviations for $k_{2}, k_{A A S} / k_{-1}, k_{H_{2} \mathrm{O}} / k_{-1}$ calculated from correlations 4.24-4.26 are $0.1 \%, 1.7 \%$ and $1.2 \%$, respectively. The calculated rates of absorption using Equations $4.24-$ 4.26 are included in Table 4.3. A good agreement between the predicted and experimental $\mathrm{JCO}_{2}$ values, with the average absolute deviation of $2.86 \%$, can be found. The activation energy for $k_{2}$ is calculated to be $43.3 \mathrm{~kJ} \cdot \mathrm{mol}^{-1}$; which is reasonably in line with the value of $36.5 \mathrm{~kJ} \cdot \mathrm{mol}^{-1}$ given by Paul and Thomsen (2012) for the temperature range of 303-323 $\mathrm{K}$. Arrhenius plots for the zwitterion mechanism rate constants are shown in Figures 4.5 and 4.6. Of the zwitterion rate constants, only $k_{2}$ is found to be strongly temperature dependent, while the ratios $k_{A A S} / k_{-1}$ and $k_{H_{2} O} / k_{-1}$ are found to be less sensitive to temperature. For temperature of $298 \mathrm{~K}$ and $2 \mathrm{~mol} \cdot \mathrm{dm}^{-3}$ solution, the contribution of water to the zwitterion deprotonation rate is found to be $72.5 \%$ and $72.7 \%$, respectively, for the potassium and sodium salts. This indicates that water contributes significantly to the deprotonation even at moderately high amino acid salt concentration. Considering the results obtained in Table 4.5, with deprotonation of the zwitterion being rate determining, reinterpretation of the kinetic data according to the termolecular mechanism (Crooks and Donnellan, 1989) could be considered. 


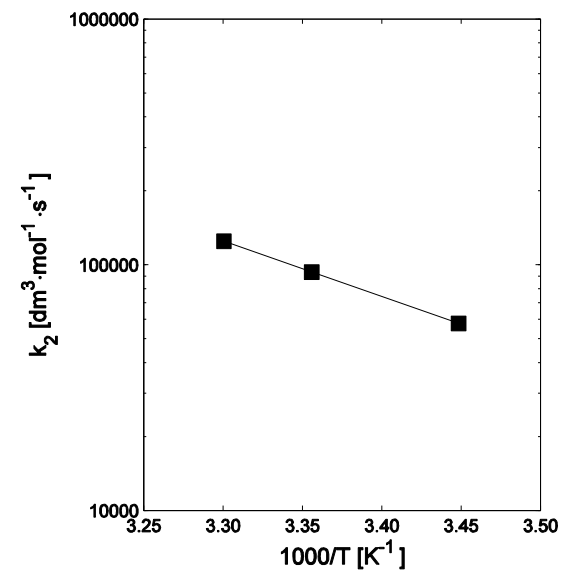

Figure 4.5: Arrhenius plot of $k_{2}$ for aqueous potassium L-prolinate solution. - , calculated with Equation 4.24

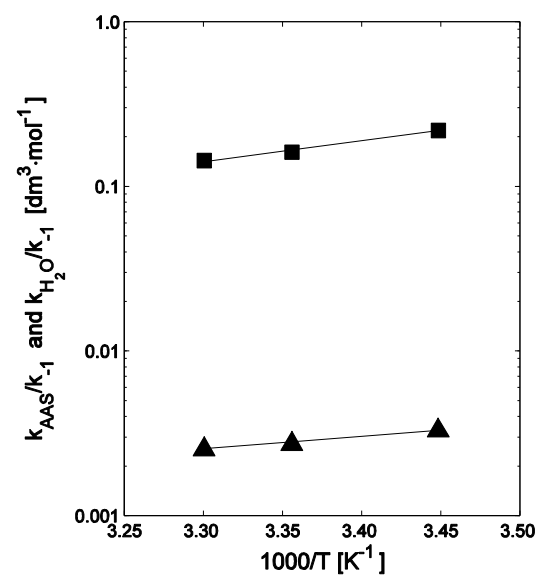

Figure 4.6: Arrhenius plot of kinetic constants ratios for aqueous potassium L-prolinate solution. -, $k_{\mathrm{H}_{2} \mathrm{O}} / k_{-1} ; \mathbf{\Lambda}, k_{A A S} / k_{-1} ;-$, calculated with Equations 4.25 and 4.26

\subsection{Conclusions}

The kinetics of the reaction between $\mathrm{CO}_{2}$ and potassium L-prolinate was estimated from the absorption data obtained in a stirred cell over the temperature range of 290-303 K and for sodium L-prolinate at $298 \mathrm{~K}$. The amino acid salt concentration was in the range of 0.5 and $3 \mathrm{~mol} \cdot \mathrm{dm}^{3}$. The kinetic data were found to be consistent with the zwitterion mechanism with deprotonation being the rate determining step. The reaction order with 
respect to the amino acid, assuming power-law kinetics, was found to be between 1.40 and 1.44 for both considered salts, indicating significant contributions from both L-prolinate and water to the zwitterion deprotonation. The potassium based-solvent showed, on average, a $32 \%$ higher reactivity towards $\mathrm{CO}_{2}$ than the sodium equivalent, and has a higher reactivity towards $\mathrm{CO}_{2}$ than most of (alkanol)amines and amino acid salts. Potassium prolinate may be therefore attractive in the bulk removal of $\mathrm{CO}_{2}$; either as a solvent or as an 'activator' to other high capacity, low energy $\mathrm{CO}_{2}$ capture solutions. 


\section{Nomenclature}

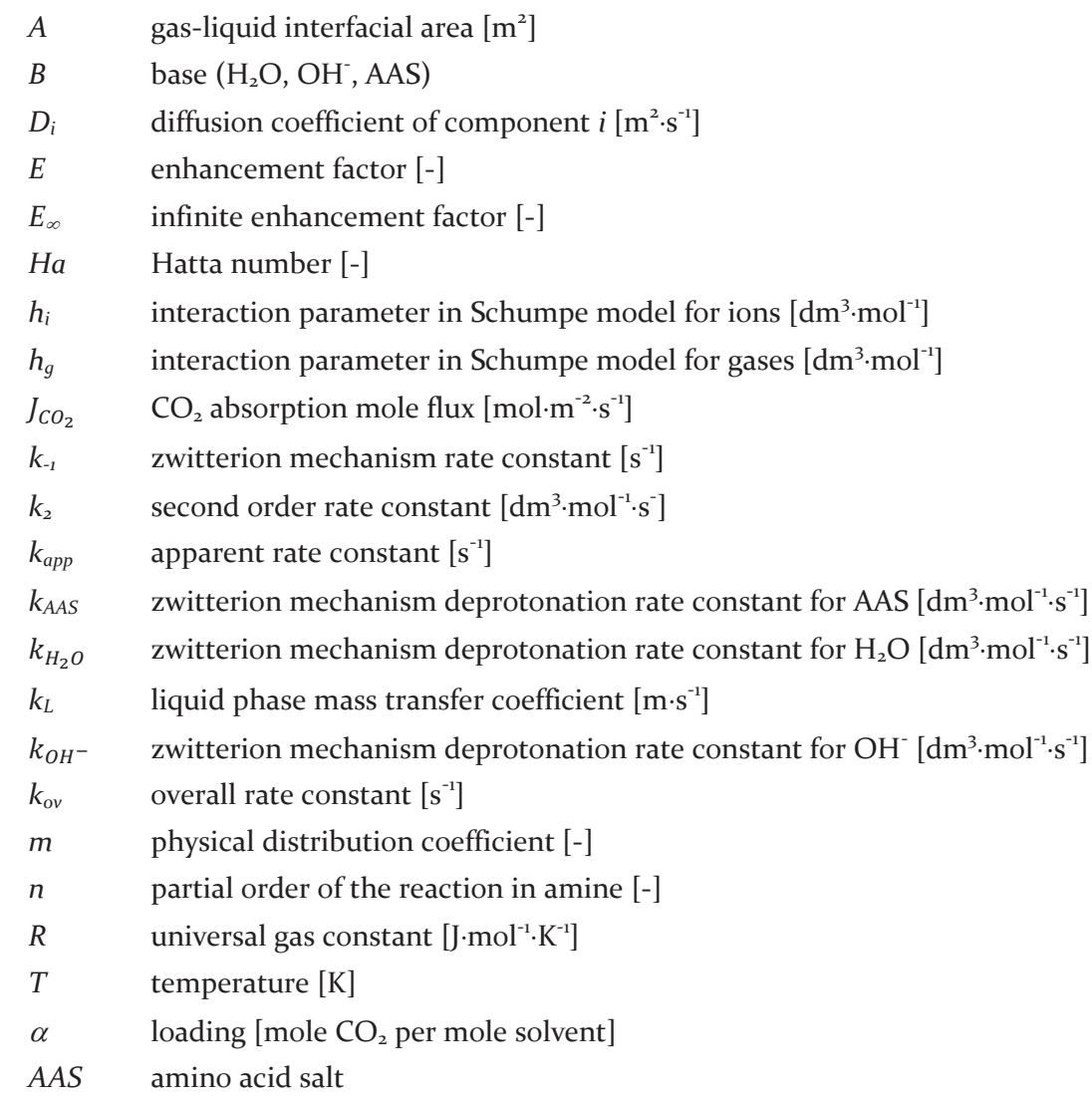




\section{Appendix}

The density and dynamic viscosity aqueous solutions of potassium, sodium and lithium salts of L-proline were measured over the temperature range of 284-313 K and for solution concentrations of $0.1 \mathrm{M}$ to the maximum concentration (as given by Majchrowicz et al., 2009). The solubility of $\mathrm{N}_{2} \mathrm{O}$ in aqueous L-prolinate solutions was measured at the same range of temperatures and solution concentrations; showing typical "salting out" behaviour. The physical solubility of $\mathrm{CO}_{2}$ can then be calculated based on the solubility of $\mathrm{CO}_{2}$ in water (Versteeg and van Swaaij, 1988) and with the use of the Schumpe model (Weisenberger and Schumpe, 1996).

\section{A.1 Experimental section}

The $\mathrm{N}_{2} \mathrm{O}$ [175876-44-5] gas used was obtained from Linde Gas. L-proline ((S)pyrrolidine-2-carboxylic acid, $\mathrm{C}_{5} \mathrm{H}_{9} \mathrm{NO}_{2}, \geq 98.5 \%$ ) [147-85-3], $\mathrm{KOH}(\geq 85.0 \%$; with the actual purity determined accurately by titration) [1310-58-3], $\mathrm{NaOH}(\geq 98.0 \%)$ [1310-65-2], $\mathrm{LiOH}$ $(\geq 98.0 \%)$ [1310-65-2] were obtained from Sigma-Aldrich and used without further purification. Aqueous L-prolinate solutions were prepared by neutralizing the amino acid dissolved in deionized, double-distilled water with an equimolar quantity of an alkaline hydroxide. The amino acid salt concentration was estimated potentiometrically by titrating with a standard $1.000 \mathrm{~mol} \cdot \mathrm{dm}^{-3} \mathrm{HCl}$ solution [7647-01-o].

The density, $\rho$, of L-prolinate salts was measured using $10 \mathrm{~cm}^{3}$ pycnometers of the GayLussac type. Temperature of a water bath (Tamson) was controlled to within $\pm 0.05 \mathrm{~K}$. The kinematic viscosity was measured using the Ubbelohde-type viscometers (sizes oB, oC, 1 and $\left.{ }_{2} \mathrm{C}\right)$ purchased with a calibration. The viscometers were immersed in a large water bath (Tamson) and temperature was controlled to within $\pm 0.05 \mathrm{~K}$. The kinematic viscosity of a sample was estimated by multiplying the efflux time by the viscometer constant. The dynamic viscosity, $\mu$, was calculated by multiplying kinematic viscosity by the corresponding density. Each reported value was the average of at least three measurements with the estimated accuracy for the density and viscosity measurements, respectively, of 0.05 and $0.5 \%$,

The physical solubility experiments were carried out in the thermostatted reactor equipped with a high intensity gas inducing impeller and connected to a calibrated gas supply vessel. Details regarding the solubility apparatus and its operation have been given by Majchrowicz and Brilman (2012). A known amount of amino acid salt solution ( $\left.\cong 0.80 \mathrm{dm}^{3}\right)$ was introduced into the absorption cell and degassed by applying vacuum. The system was 
allowed to come to the vapour-liquid equilibrium at the desired temperature, which was maintained to within $\pm 0.1 \mathrm{~K}$. This pressure is recorded as the vapour pressure, $P_{\text {vap. }}$. The gas supply vessel was filled with pure $\mathrm{N}_{2} \mathrm{O}$. Then, the gas was allowed to flow into the reactor until an arbitrary pressure was reached. This pressure was recorded as the initial pressure, $P_{i n t}$. After this, the agitator in the reactor was switched on and the system was allowed to reach vapour-liquid equilibrium at which point the final pressure was recorded, $P_{\text {eq. }}$ The equilibrium pressure was generally achieved in less than $15 \mathrm{~min}$. The physical solubility was then calculated from:

$$
m=\frac{R T}{H e}=\frac{P_{\text {int }}-P_{e q}}{P_{\text {eq }}-P_{\text {vap }}} \cdot \frac{V_{g}}{V_{l}}
$$

where $V_{g}$ and $V_{l}$ are volumes of the gas and liquid phases, respectively.

\section{A.2 Results and discussion}

The density and dynamic viscosity of sodium and lithium salts of L-proline were obtained over the temperature range of $284-313 \mathrm{~K}$, for solution concentrations from o.1 M to the maximum concentration (as given by Majchrowicz et al., 2009; see also Chapter 2), and the results are reported in Tables A.1 and A.2, respectively. The experimental densities were fitted to a polynomial function in the form proposed by van Holst et al. (2008):

$$
\rho=k_{1} T+k_{2} c+k_{3}
$$

where $k_{i}$ are the polynomial coefficients presented in Table A.3. The average deviations for $\rho$ are $0.2 \%$ and $0.1 \%$ for the sodium and lithium salts, respectively. The experimental viscosities were fitted to Equation A.3 (as derived by van Holst et al., 2008):

$$
\mu=k_{1} \exp \left[\frac{k_{2} \exp \left(k_{3} C_{m}\right)}{R T}\right] \exp \left(k_{4} C_{m}\right)
$$

The $k_{i}$ coefficients in this equation are reported in Table A.4. The average deviations for $\mu$ are $4.1 \%$ and $3.7 \%$ for the sodium and lithium salts, respectively. Van Holst et al. (2008) measured the density and dynamic viscosity of aqueous potassium L-prolinate solutions at temperatures of 298-333 $\mathrm{K}$ and amino acid salt concentrations of $0.5-3.5 \mathrm{~mol} \cdot \mathrm{dm}^{-3}$. Their $\rho$ and $\mu$ data for the potassium salt were included in Tables A.1 and A.2. The data points at temperature of $284 \mathrm{~K}$ for $\rho$ and $\mu$ were extrapolated from their data using Equation A.2 and A.3. Generally, the density of the amino acid salt increases in the order of $\mathrm{K}^{+}>\mathrm{Na}^{+}>\mathrm{Li}^{+}$; while for the dynamic viscosity no clear trend could be observed. The density decreases and 
increases, respectively, with increasing temperature and amino acid salt concentration. The dynamic viscosity decreases exponentially with an increase in temperature but increases with increasing solution concentration.

Table A.1: Density of aqueous alkaline salts of L-proline

\begin{tabular}{lccccc}
\hline Solvent & $T[\mathrm{~K}]$ & 284 & 298 & 303 & 313 \\
\cline { 2 - 6 } & $C_{m}[\mathrm{M}]$ & \multicolumn{3}{c}{$\rho\left[\mathrm{g} \cdot \mathrm{cm}^{-3}\right]$} \\
\hline Potassium L-prolinate & 0.51 & 1.038 & 1.028 & 1.027 & 1.023 \\
& 1.01 & 1.066 & 1.059 & 1.057 & 1.053 \\
& 1.52 & 1.096 & 1.089 & 1.087 & 1.082 \\
& 2.01 & 1.123 & 1.118 & 1.115 & 1.110 \\
Sodium L-prolinate & 2.52 & 1.152 & 1.146 & 1.144 & 1.138 \\
& 2.98 & 1.178 & 1.171 & 1.168 & 1.162 \\
& 3.45 & 1.205 & 1.197 & 1.194 & 1.188 \\
& 0.10 & 1.007 & 1.003 & 1.003 & 1.001 \\
& 0.51 & 1.030 & 1.026 & 1.025 & 1.023 \\
& 1.03 & 1.058 & 1.053 & 1.052 & 1.050 \\
& 2.03 & 1.113 & 1.106 & 1.105 & 1.102 \\
& 2.98 & 1.163 & 1.155 & 1.153 & 1.150 \\
& 4.05 & 1.211 & 1.204 & 1.201 & 1.197 \\
& 0.09 & 1.005 & 1.001 & 1.000 & 0.999 \\
& 0.49 & 1.020 & 1.017 & 1.016 & 1.015 \\
& 0.99 & 1.040 & 1.037 & 1.036 & 1.034 \\
& 1.84 & 1.075 & 1.070 & 1.069 & 1.067 \\
\hline
\end{tabular}


Table A.2. Dynamic viscosity of aqueous alkaline salts of L-proline

\begin{tabular}{|c|c|c|c|c|c|}
\hline \multirow[t]{2}{*}{ Solvent } & $T[\mathrm{~K}]$ & 284 & 298 & 303 & 313 \\
\hline & $C_{m}[\mathrm{M}]$ & \multicolumn{4}{|c|}{$\mu\left[\mathrm{mPa} \cdot \mathrm{s}^{-1}\right]$} \\
\hline \multirow[t]{7}{*}{ Potassium L-prolinate } & 0.51 & 1.600 & 1.107 & 0.986 & 0.799 \\
\hline & 1.01 & 2.035 & 1.400 & 1.242 & 0.992 \\
\hline & 1.52 & 2.662 & 1.811 & 1.59 & 1.251 \\
\hline & 2.01 & $3 \cdot 510$ & 2.365 & 2.061 & 1.599 \\
\hline & 2.52 & 4.809 & 3.163 & 2.721 & 2.076 \\
\hline & 2.98 & 6.540 & 4.112 & $3 \cdot 516$ & 2.664 \\
\hline & 3.45 & 9.117 & $5 \cdot 732$ & 4.837 & $3 \cdot 587$ \\
\hline \multirow[t]{6}{*}{ Sodium L-prolinate } & 0.10 & 1.388 & 0.929 & 0.822 & 0.682 \\
\hline & 0.51 & 1.776 & 1.163 & 1.057 & 0.843 \\
\hline & 1.03 & 2.517 & 1.587 & 1.405 & 1.103 \\
\hline & 2.03 & 5.436 & 3.169 & 2.638 & 2.036 \\
\hline & 2.98 & 13.429 & $7 \cdot 935$ & 5.615 & 4.174 \\
\hline & 4.05 & 41.297 & $17 \cdot 901$ & $14 \cdot 461$ & $9 \cdot 384$ \\
\hline \multirow[t]{4}{*}{ Lithium L-prolinate } & 0.09 & 1.406 & 0.931 & 0.915 & 0.792 \\
\hline & 0.49 & 1.832 & 1.190 & 1.049 & 0.839 \\
\hline & 0.99 & 2.623 & 1.648 & 1.445 & 1.126 \\
\hline & 1.84 & $5 \cdot 598$ & 3.122 & 2.654 & 2.049 \\
\hline
\end{tabular}

Table A.3: Coefficients in Equation A.2

\begin{tabular}{lcccl}
\hline Solvent & $k_{1} \times 10^{4}$ & $k_{2} \times 10^{2}$ & $k_{3}$ & Source \\
\hline Potassium L-prolinate & -5.258 & 5.602 & 1.160 & Van Holst et al. (2008) \\
Sodium L-prolinate & -3.225 & 5.112 & 1.097 & this work \\
Lithium L-prolinate & -2.077 & 3.876 & 1.060 & this work \\
\hline
\end{tabular}

Table A.4: Coefficients in Equation A.3

\begin{tabular}{lccccl}
\hline Solvent & $k_{1} \times 10^{3}$ & $k_{2} \times 10^{-3}$ & $k_{3}$ & $k_{4}$ & Source \\
\hline Potassium L-prolinate & 1.534 & 15.85 & 0.1071 & -0.3025 & Van Holst et al. (2008) \\
Sodium L-prolinate & 0.146 & 21.59 & 0.1009 & -0.3434 & this work \\
Lithium L-prolinate & 0.398 & 19.30 & 0.1734 & -0.9252 & this work \\
\hline
\end{tabular}

The physical solubility of $\mathrm{N}_{2} \mathrm{O}$ in water, $m_{N_{2} O, H_{2} O}$, was determined as a function of temperature to validate the operation of the experimental apparatus. The results of this study are plotted in Figure A.1. From the figure, it is clear that the measured solubilities are well in line with the literature data. Next, the solubility of $\mathrm{N}_{2} \mathrm{O}$ in aqueous solutions of potassium and sodium salts of L-proline, $m_{N_{2} O}$, were obtained for temperatures of $284-313 \mathrm{~K}$ and solution concentrations of $0.1-3.0 \mathrm{~mol} \cdot \mathrm{dm}^{-3}$. The results are shown in Figure A.2. No 
significant impact of a counterion on the $\mathrm{N}_{2} \mathrm{O}$ solubility in aqueous L-prolinate solutions was found. Van Holst et al. (2009) measured the physical distribution of $\mathrm{N}_{2} \mathrm{O}$ in potassium and lithium salts of the considered amino acid in the temperature range of 298-333 K. As in the present case, differences in the values of $m_{N_{2} O}$ for both salts were within the accuracy of measurements. Using the experimental results of the $\mathrm{N}_{2} \mathrm{O}$ solubility from the present work and Equations 4.17 to 4.19 , the anion specific parameter for L-prolinate was calculated - see Table A.5. In this table, the $h_{-}$values for L-prolinate reported by van Holst et al. (2009) and Paul and Thomsen (2012) are also included. The $h_{-}$values from the present work agree within $5.3 \%$ with the literature data. As shown in this table, the obtained value of $h_{-}$for the considered amino acid decreases with temperature. This behaviour was also reported by Portugal et al. (2008) for solubility of $\mathrm{N}_{2} \mathrm{O}$ in aqueous solutions of potassium threoninate.

Table A.5. Ion specific parameter for L-prolinate

\begin{tabular}{lccccc}
\hline & \multicolumn{5}{c}{$h_{-}\left[\mathrm{dm}^{3} \cdot \mathrm{mol}^{-1}\right]$} \\
\cline { 2 - 6 }$T[\mathrm{~K}]$ & 290 & 298 & 303 & 313 & 323 \\
\hline this work & 0.0841 & 0.0751 & 0.0648 & 0.0562 & \\
Paul and Thomsen (2012) & & & 0.0676 & 0.0592 & 0.0505 \\
Van Holst et al. (2009) & & 0.0740 & & & \\
\hline
\end{tabular}

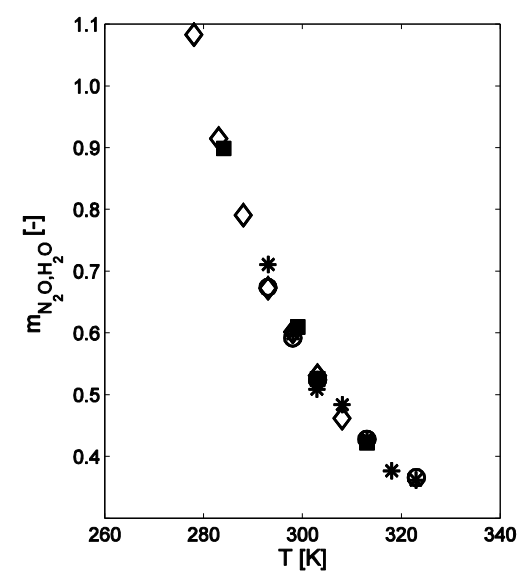

Figure A.1. Physical distribution coefficient of $\mathrm{N}_{2} \mathrm{O}$ in water as a function of temperature. $\mathbf{m}$, this work; $\diamond$, Derks et al. (2006); O, Perry and Green (1997); *, Versteeg and van Swaaij (1988) 


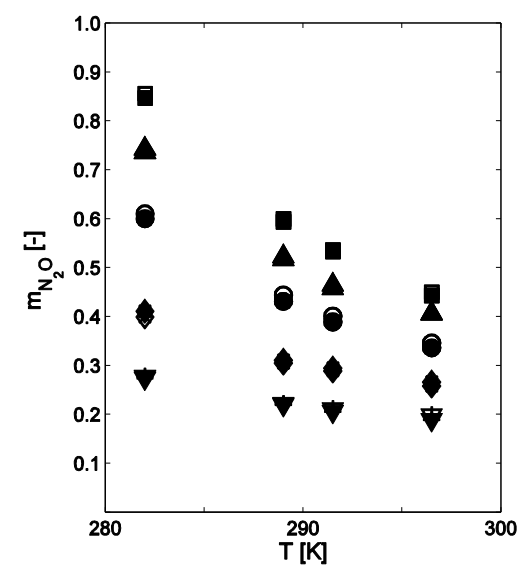

Figure A.2. Physical distribution coefficient of $\mathrm{N}_{2} \mathrm{O}$ in alkaline salts of L-proline. Closed symbols for the potassium salt and open symbols for the sodium salt. $\square$, o.1 M; $\Delta$, o.5 M; O, 1.o M; $\diamond$, 2.o M; $\nabla, 3 \mathrm{M}$ 


\section{Bibliography}

Blauwhoff, P.M.M., Versteeg, G.F., van Swaaij, W.P.M., 1984. A study on the reaction between $\mathrm{CO}_{2}$ and alkanolamines in aqueous solutions. Chemical Engineering Science 39, 207-225

Caplow, M., 1968. Kinetics of carbamate formation and breakdown. Journal of American Chemical Society 90, 6796-6803

Crooks, J. E., Donnellan, J. P., 1989. Kinetics and mechanism of the reaction between carbon dioxide and amines in aqueous solution. Journal of the Chemical Society, Perkin Transactions 2 , $331-333$

Danckwerts, P.V., 1970. Gas-liquid reactions. McGraw-Hill Book Company, New York

Danckwerts, P.V., 1979. The reaction of $\mathrm{CO}_{2}$ with ethanolamines. Chemical Engineering Science 34, $443-446$

DeCoursey, W.J., 1974. Absorption with chemical reaction: development of a new relation for the Danckwerts model. Chemical Engineering Science 29, 1867-1872

Derks, P.W.J., Kleingeld, T., van Aken, C., Hogendoorn, J.A., Versteeg, G.F., 20o6. Kinetics of absorption of carbon dioxide in aqueous piperazine solutions. Chemical Engineering Science 61, 6837-6854

Gubbins, K.E., Bhatia, K.K., Walker, R.D., 1966. Diffusion of gases in electrolytic solutions. American Institute of Chemical Engineers Journal 12, 548-552

Hamborg, E.S., van Swaaij, W.P.M., Versteeg, G.F., 2008. Diffusivities in aqueous solutions of the potassium salt of amino acids. Journal of Chemical and Engineering Data 53, 1141-1145

Haubrock, J., Hogendoorn, J.A., Versteeg, G.F., 2007. The applicability of activities in kinetic expressions: a more fundamental approach to represent the kinetics of the system $\mathrm{CO}_{2}-\mathrm{OH}^{-}$salt in terms of activities. Chemical Engineering Science 62, 5753-5769

Higbie, R., 1935. The rate of absorption of a pure gas into a still liquid during a short time of exposure. Transactions of the American Institute of Chemical Engineers 31, 365-389

Hikita, H., Asai, S., 1976. Gas absorption with a two step chemical reaction. The Chemical Engineering Journal 11, 123-129

Van Holst, J., Kersten S.R.A., Hogendoorn, K.J., 2008. Physicochemical properties of several aqueous amino acid salts. Journal of Chemical Engineering Data 53, 1286-1291

Van Holst, J., Versteeg, G.F., Brilman, D.W.F., Hogendoorn, J.A., 20o9. Kinetic study of $\mathrm{CO}_{2}$ with various amino acid salts in aqueous solution. Chemical Engineering Science 64, 59-58

Hook, R.J., 1997. An investigation of some sterically hindered amines as potential carbon dioxide scrubbing compounds. Industrial and Engineering Chemistry Research 36, 1779-179o 
Kohl, A.L., Nielsen, R.B., 1997. Gas Purification: $5^{\text {th }}$ Edition. Gulf Publishing Company, Houston

Kumar, P.S., Hogendoorn, J.A., Feron, P.H., Versteeg, G.F., 20o1. Density, viscosity, solubility, and diffusivity of $\mathrm{N}_{2} \mathrm{O}$ in aqueous amino acid salt solutions. Journal of Chemical Engineering Data 46, $1357-1361$

Kumar, P.S., Hogendoorn, J.A., Feron, P.H., Versteeg, G.F., 2003. Kinetics of the reaction of $\mathrm{CO}_{2}$ with aqueous potassium salt of taurine and glycine. American Institute of Chemical Engineers Journal 49, 203-213

Laddha, S.S., Diaz, J.M., Danckwerts, P.V., 1981. The $\mathrm{N}_{2} \mathrm{O}$ analogy: the solubilities of $\mathrm{CO}_{2}$ and $\mathrm{N}_{2} \mathrm{O}$ in aqueous solutions of organic compounds. Chemical Engineering Science 36, 228-229

Laddha, S.S., Danckwerts, P.V., 1981. Reaction of $\mathrm{CO}_{2}$ with ethanolamines: kinetics from gasabsorption. Chemical Engineering Science 36, 479-482

Majchrowicz, M.E., Brilman, D.W.F., Groeneveld, M.J., 2009. Precipitation regime for selected amino acid salts for $\mathrm{CO}_{2}$ capture from flue gases. Energy Procedia 1, 979-984

Majchrowicz, M.E., Brilman, D.W.F., 2012. Solubility of $\mathrm{CO}_{2}$ in aqueous potassium L-prolinate solutions - absorber conditions. Chemical Engineering Science 72, 35-44

Paul, S., Thomsen, K., 2012. Kinetics of absorption of carbon dioxide into aqueous potassium salt of proline. International Journal of Greenhouse Gas Control 8, 169-179

Park, S.W., Choi, B.S., Oh, K.J., Lee, J.W., 2007. Absorption of carbon dioxide into aqueous PAA solution containing diethanolamine. Journal of the Chinese Institute of Chemical Engineers 38, 461466

Perry, R.H., Green, D.W., 1997. Perry's chemical engineers handbook: $6^{\text {th }}$ Edition. McGraw-Hill

Pohorecki, R., Moniuk, W., 1988. Kinetics of the reaction between carbon dioxide and hydroxyl ion in aqueous electrolyte solutions. Chemical Engineering Science 43, 1677-1684

Popiel, C.O., Wojtkowiak, J., 1998. Simple formulas for thermophysical properties of liquid water for heat transfer calculations (from $0^{\circ} \mathrm{C}$ to $150^{\circ} \mathrm{C}$ ). Heat Transfer Engineering 19, 87-101

Portugal, A.F., Derks, P.W.J., Versteeg, G.F., Magalhães, F.D., Mendes, A., 2007. Characterization of potassium glycinate for carbon dioxide absorption purposes. Chemical Engineering Science 62, 6534-6547

Portugal, A.F., Magalhães, F.D., Mendes, A., 2008. Carbon dioxide absorption kinetics in potassium threonate. Chemical Engineering Science 63, 3493-3503

Shao, R., Stangeland, A., 20o9. Amines used in $\mathrm{CO}_{2}$ capture - health and environmental impacts. Bellona Report

Simons, K, Nijmeijer, K., Mengers H., Brilman W., Wessling, M., 2010a. Highly selective amino acid salt solutions as absorption liquid for $\mathrm{CO}_{2}$ capture in gas-liquid membrane contactors. ChemSusChem 3, 939-947 
Simons, K., Brilman, D.W.F., Mengers, H., Nijmeijer, K., Wessling, M., 2o1ob. Kinetics of $\mathrm{CO}_{2}$ absorption in aqueous sarcosine salt solutions: influence of concentration, temperature, and $\mathrm{CO}_{2}$ loading. Industrial and Engineering Chemistry Research 49, 9693-9702

Van Swaaij, W.P.M., Versteeg, G.F., 1992. Mass transfer accompanied with complex reversible chemical reaction in gas-liquid systems: an overview. Chemical Engineering Science 47, 3181-3195

Versteeg, G.F., van Swaaij, W.P., 1988. Solubility and diffusivity of acid gases (carbon dioxide, nitrous oxide) in aqueous alkanolamine solutions. Journal of Chemical Engineering Data 33, 29-34

Versteeg, G.F., Oyevaar, M.H., 1989. The reaction between $\mathrm{CO}_{2}$ and diethanolamine at $298 \mathrm{~K}$. Chemical Engineering Science 44, 1264-1268

Versteeg, G.F., van Dijck, L.A.J., van Swaaij, W.P.M., 1996. On the kinetics between $\mathrm{CO}_{2}$ and alkanolamines both in aqueous and non-aqueous solutions. An overview. Chemical Engineering Communications 144, 113-158

Vučak, M., Perić, J., Žmikić, A., Pons, M.N., 2002. A study of carbon dioxide absorption into aqueous monoethanolamine solution containing calcium nitrate in the gas-liquid reactive precipitation of calcium carbonate. Chemical Engineering Journal 28, 171-179

Weisenberger S., Schumpe, A., 1996. Estimation of gas solubilities in salt solutions at temperatures from 273 to 363 K. American Institute of Chemical Engineers Journal 42, 298-300 

Chapter 5

\title{
Amino Acid Salts for Carbon Dioxide Capture - Evaluating L-Prolinate at Desorber Conditions
}

\begin{abstract}
Vapour-liquid equilibrium (VLE) measurements for unloaded- and for $\mathrm{CO}_{2}$ saturated aqueous potassium salt solutions of L-proline have been performed using a highpressure equilibrium cell. The solubility of $\mathrm{CO}_{2}$ has been determined at temperatures of 363, 393 and $403 \mathrm{~K}$, in 3 and $4 \mathrm{~mol} \cdot \mathrm{dm}^{-3}$ aqueous solutions. The $\mathrm{CO}_{2}$ partial pressures ranged from 3.0 to $358 \mathrm{kPa}$. In addition, the VLE data for $\mathrm{CO}_{2}$-free and saturated $3 \mathrm{~mol} \cdot \mathrm{dm}^{-3}$ aqueous potassium sarcosinate solutions are presented for the same range of temperatures. The vapour pressures of the considered compounds have been determined at temperatures from 353 to $403 \mathrm{~K}$. The reboiler duty required for stripping $\mathrm{CO}_{2}$ from potassium L-prolinate solutions has been computed by the summation of the desorption enthalpy of $\mathrm{CO}_{2}$, the sensible heat and the evaporation heat associated with co-produced regenerator overhead water vapour. A new approach to calculate the latter contribution is presented. The calculated energy requirements for L-prolinate are in the range reported in open literature for other amino acid salts.
\end{abstract}




\subsection{Introduction}

Nowadays, carbon dioxide $\left(\mathrm{CO}_{2}\right)$ is widely recognized as a major greenhouse gas contributing to long-term climate changes. Based on technologies available today, postcombustion removal of $\mathrm{CO}_{2}$ by use of absorption with chemical solvents such as (alkanol)amines and amino acid salts (AAS) is considered to be most cost-effective and viable option for a large-scale $\mathrm{CO}_{2}$ capture from flue gases. In the amine-based gas cleaning units, it is the regeneration of the $\mathrm{CO}_{2}$-loaded liquid that mainly determines the operational costs of the process. This cost is due to a large amount of heat required to reverse the amine-acid gas reaction, to bring rich solvent from the absorber (after feed-product heat exchange) to regenerator conditions and energy for evaporating the co-produced regenerator overhead water vapour.

This reboiler duty can be measured experimentally in pilot plant units (Knuutila et al., 2011; Lee et al., 2010; Sakwattanapong et al., 2005), it can be estimated by rigorous column modelling using dedicated software and advanced thermodynamic models (Abu Zahra, 2009) or estimated by the summation of above-mentioned components of the overall regeneration energy, determined separately (Rochelle et al., 2001; Song et al., 2008).

To obtain an (initial) indication of the energy required for a regenerative amine-based process, the latter procedure is often applied. Lee et al. (2010) evaluated the regeneration energy and degree of $\mathrm{CO}_{2}$ removal for aqueous solution of monoethanolamine (MEA) as a function of process parameters in a bench scale $\mathrm{CO}_{2}$ capture process. For the verification of experimental results, the regeneration energy was also computed by the summation of the enthalpy of reaction, the sensible heat and the heat of water vaporization using their process data. The calculated reboiler duty was in good agreement with the data from the bench scale tests, within $6 \%$. Song et al. (2008) estimated the reboiler duty for $\mathrm{CO}_{2}$ absorption in aqueous solutions of MEA and sodium salt of glycine as the sum of these three terms. The physico-chemical properties and the heat associated data required in the calculations were determined experimentally. No information is given, however, on the method of establishing the $\mathrm{H}_{2} \mathrm{O}: \mathrm{CO}_{2}$ overhead (reflux-) ratio; which is a crucial parameter in this type of calculations.

In the present work, an estimation method to calculate the reboiler duty is presented with a new approach to determine the $\mathrm{H}_{2} \mathrm{O}: \mathrm{CO}_{2}$ overhead ratio. This ratio of partial pressures of water vapour and $\mathrm{CO}_{2}$ in the gas phase at the desorber outlet (top) is here referred to as the "reflux ratio". To validate the model developed in this work, the reboiler duty for stripping $\mathrm{CO}_{2}$ from aqueous $5 \mathrm{M}$ MEA solution was calculated with the current method and compared with the data obtained with the module available in the Aspen Plus v8.o (here referred to as 
the working Aspen Plus Example). After that, the energy requirements for potassium L-prolinate solution has been computed and compared with the literature numbers found for other amino acid salts.

While a number of publications on the experimental $\mathrm{CO}_{2}$ solubility data can be found for (alkanol)amines, the literature data for $\mathrm{CO}_{2}$-AAS- $\mathrm{H}_{2} \mathrm{O}$ systems is relatively scarce and in majority dealing with the absorption side. Table 5.1 summarizes the conditions of the $\mathrm{CO}_{2}$ solubility measurements for amino acid salt solutions as reported in open literature. The vapour-liquid equilibrium (VLE) data, with and without $\mathrm{CO}_{2}$ in the system, are needed in the reboiler duty calculation. In the present work, the VLE curves of $\mathrm{CO}_{2}$-satured, 3 and $4 \mathrm{~mol} \cdot \mathrm{dm}^{-3}$ aqueous solutions of potassium salt of L-proline were obtained for the $\mathrm{CO}_{2}$ partial pressure range of 3.0 to $358 \mathrm{kPa}$. Since at temperatures greater than $398 \mathrm{~K}$ an accelerated MEA degradation has been reported (Movagharnejad and Akbari, 2011), the experimental procedures followed were validated using potassium salt of sarcosine. The VLE data for $3 \mathrm{~mol} \cdot \mathrm{dm}^{-3}$ sarcosinate solution in the $\mathrm{CO}_{2}$ partial pressure range of 3.3 to $253 \mathrm{kPa}$ were measured. For both amino acids, the experiments were carried out at temperatures of 363, 393 and $403 \mathrm{~K}$. The vapour pressures of the considered compounds were determined at temperatures from 353 to $403 \mathrm{~K}$. This work is part of a set of studies aiming to identify the potential of potassium salt of L-proline as $\mathrm{CO}_{2}$ absorbent.

Table 5.1: Literature sources for the vapour-liquid equilibrium data of $\mathrm{CO}_{2}-\mathrm{AAS}-\mathrm{H}_{2} \mathrm{O}$ systems

\begin{tabular}{|c|c|c|c|c|}
\hline Solvent & $\begin{array}{c}C_{m} \\
{\left[\mathrm{~mol} \cdot \mathrm{dm}^{-3}\right]}\end{array}$ & $\begin{array}{c}T \\
{[\mathrm{~K}]}\end{array}$ & $\begin{array}{l}p_{\mathrm{CO}_{2}} \\
{[\mathrm{kPa}]}\end{array}$ & Source \\
\hline \multirow[t]{2}{*}{ Potassium taurate } & $0.5-3,4$ & $298^{*}$ & $0.107-7.396$ & Kumar et al. (2002) \\
\hline & 1 & 313 & $0.208-5.286$ & \\
\hline \multirow[t]{2}{*}{ Sodium glycinate } & $1-3 \cdot 5$ & $303-323$ & $0.1-214$ & Song et al. (2006) \\
\hline & $3 \cdot 5$ & $313-393$ & $0.1-400$ & Song et al. (2008) \\
\hline Potassium glycinate & $0.1-3$ & $283-351$ & $0.54-63.4$ & Portugal et al. (2009) \\
\hline Potassium threonate & 1 & 313 & $1.03-42.0$ & Portugal et al. (2009) \\
\hline \multirow[t]{2}{*}{ Potassium sarcosinate } & $3 \cdot 5$ & $313-353$ & $0.029-14 \cdot 585$ & Aronu et al. (2011) \\
\hline & $3 \cdot 5$ & $373-393$ & $38.1-1051$ & \\
\hline Potassium serinate & 1 & $313-373$ & $0.1-400$ & Song et al. (2011) \\
\hline Potassium DL-methioninate & 0.5 & 353 & $1280-8570$ & Kumełan et al. (2010) \\
\hline \multirow[t]{2}{*}{ Potassium L-prolinate } & $0.5^{-2}$ & $298-313$ & $0.5^{1-70.1}$ & Majchrowicz and \\
\hline & $3^{*}$ & $285^{*}, 298-323$ & $2.02-35.4$ & Brilman (2012) \\
\hline
\end{tabular}

At these conditions the solids precipitation is observed 


\subsection{Material and methods}

The $\mathrm{CO}_{2}$ (min. 99.99 mol\%) [124-38-9] gas used was purchased from Linde Gas. L-proline ( $(S)$-pyrrolidine-2-carboxylic acid, $\left.\mathrm{C}_{5} \mathrm{H}_{9} \mathrm{NO}_{2}, \geq 98.5 \%\right)$ [147-85-3], sarcosine (N-methylglycine, $\mathrm{C}_{3} \mathrm{H}_{7} \mathrm{NO}_{2} \geq 98.0 \%$ ) [107-97-1], $\mathrm{KOH}$ ( $\geq 85.0 \%$; with the actual purity determined accurately by titration) [1310-58-3] were purchased from Sigma-Aldrich and applied without further purification. Amino acid salt solutions were prepared by neutralizing the amino acid dissolved in deionized, double-distilled water by using an equimolar quantity of potassium hydroxide. For this the actual purity of potassium hydroxide was utilized. The actual concentration of the amino acid salt solution was determined potentiometrically by titrating with a standard $1.000 \mathrm{~mol} \cdot \mathrm{dm}^{-3} \mathrm{HCl}$ solution [7647-01-o].

The vapour-liquid equilibrium set-up consisted of an autoclave made of 316 SS $\left(\cong 0.267 \mathrm{dm}^{3}\right)$, a $\mathrm{CO}_{2}$ supply vessel $\left(\cong 0.520 \mathrm{dm}^{3}\right)$ and a vacuum pump. The equilibrium cell was equipped with a high intensity gas inducing stirrer, digital pressure sensors, and a PTioo temperature sensor (in the liquid phase). It was heated by a thermostatic oil circulator. The gas supply vessel was provided with a digital pressure sensor and a PT1oo temperature sensor. In all experiments, a known amount of a solution was introduced into the equilibrium cell and degassed by applying vacuum. In the vapour pressure experiment, a $\mathrm{CO}_{2}$-free solution was heated up to a desired temperature. Once the system reached an equilibrium state, temperature and pressure in the autoclave were recorded. Samples were analyzed before and after each experiment to check for any concentration variation due to losses during evacuation or by degradation. In the $\mathrm{CO}_{2}$ solubility experiments, known portions of pure $\mathrm{CO}_{2}$ was added to the autoclave, after which the stirrer was started and the system was allowed to reach equilibrium. The amount of $\mathrm{CO}_{2}$ absorbed by the solution was calculated from the pressure drop in the $\mathrm{CO}_{2}$ supply vessel in combination with the ideal gas law corrected for the gas phase non-ideality by applying a compressibility factor $Z=f\left(p_{\mathrm{CO}_{2}}, T\right)$ (Turlington and McKetta, 1961; Perry and Green, 1965). More details about the experimental procedure and calculations used in this study can be found in work by van Holst et al. (2008) and Portugal et al. (2009).

\subsection{Reboiler duty}

The heat required to regenerate a solvent solution in the stripper column of $\mathrm{CO}_{2}$ capture process (reboiler duty, $Q_{\text {reb }}$ ) depends on three terms (Kohl and Nielsen, 1997; Song et al., 2008; Oexmann and Kather, 2010): 


$$
Q_{\text {reb }}=Q_{\text {sens }}+Q_{\text {des }, \mathrm{CO}_{2}}+Q_{v a p, \mathrm{H}_{2} \mathrm{O}}
$$

where $Q_{\text {sens }}$ is the sensible heat to raise a solvent solution from temperature of the loaded solvent downstream the rich-lean heat exchanger to the reboiler temperature, $Q_{v a p, \mathrm{H}_{2} \mathrm{O}}$ is the heat of evaporation required to produce the stripping steam leaving the column overhead, and $Q_{d e s, \mathrm{CO}_{2}}$ is the overall heat required to desorb $\mathrm{CO}_{2}$ from the loaded solvent. All these heat requirements are calculated in $\mathrm{MJ} \cdot \mathrm{kg}^{-1} \mathrm{CO}_{2}$. The quantities of these three terms are calculated as follows:

$$
\begin{gathered}
Q_{\text {sens }}=\frac{\rho C_{p} \Delta T}{\Delta \alpha C_{m} M_{\mathrm{CO}_{2}}} \\
Q_{d e s, \mathrm{CO}_{2}}=\frac{\Delta H_{d e s, \mathrm{CO}_{2}}}{M_{\mathrm{CO}_{2}}} \\
Q_{v a p, \mathrm{H}_{2} \mathrm{O}}=\frac{R \Delta H_{v a p, \mathrm{H}_{2} \mathrm{O}} M_{\mathrm{H}_{2} \mathrm{O}}}{M_{\mathrm{CO}_{2}}}
\end{gathered}
$$

where $\Delta \alpha$ is the difference in $\mathrm{CO}_{2}$ liquid loading between the absorber outlet (rich) and inlet (lean) and is expressed (in mole $\mathrm{CO}_{2}$ per mole solvent), $R$ is the molar ratio of $\mathrm{H}_{2} \mathrm{O}: \mathrm{CO}_{2}$ in the regenerator overhead stream, $\Delta H_{d e s, \mathrm{CO}_{2}}$ is the enthalpy of desorption, $\Delta \mathrm{H}_{v a p, \mathrm{H}_{2} \mathrm{O}}$ is the heat of water evaporation, $\mathrm{M}_{\mathrm{CO}_{2}}$ and $\mathrm{M}_{\mathrm{H}_{2} \mathrm{O}}$ are molar weights of $\mathrm{CO}_{2}$ and water, respectively. The remaining parameters are defined in Table 5.2. For the heat required to strip $\mathrm{CO}_{2}$ from the solution, $Q_{\mathrm{des} \mathrm{CO}_{2}}$, the (average) enthalpy of desorption is required and can be calculated using Equations 5.5 and 5.6 (Kohl and Nielsen, 1997).

$$
\begin{gathered}
\frac{\Delta H_{\text {diff }}}{R}=\left[\frac{\partial \ln p_{\mathrm{CO}_{2}}}{\partial\left(\frac{1}{T}\right)}\right]_{\alpha} \\
\Delta H_{\text {avg }}=\frac{1}{\Delta \alpha} \int_{\alpha_{\text {lean }}}^{\alpha_{\text {rich }}} \Delta H_{\text {diff }} \mathrm{d} \alpha
\end{gathered}
$$

In Equation 5.3, $R$ is the quantity of stripping vapour (mole $\mathrm{H}_{2} \mathrm{O}$ ) provided per mole of $\mathrm{CO}_{2}$ produced. This ratio is estimated via the ratio of partial pressures of water vapour and $\mathrm{CO}_{2}$ in the gas phase at the desorber outlet (top). According to literature, this ratio in commercial columns is in the range of 0.3 to 3.0 mole water per mole acid gas (Kohl and Nielsen, 1997); with the highest reflux found for MEA (2-3), followed by DEA (1.5) and MDEA (0.3-1.o). Alternative to assuming a "typical figure", based on a thermodynamic analysis, Oexmann and Kather (2010) proposed to estimate this ratio from: 


$$
\frac{p_{\mathrm{H}_{2} \mathrm{O}}^{S}}{p_{C O_{2}}^{*}}=\frac{p_{\mathrm{H}_{2} \mathrm{O}, \text { ref }}^{s}}{p_{C O_{2}, \text { ref }}^{*}} \exp \left(\left[\frac{T-T_{\text {ref }}}{R T T_{\text {ref }}}\right]\left(\left|\Delta H_{v a p, \mathrm{H}_{2} \mathrm{O}}\right|-\left|\Delta H_{a b s, C O_{2}}\right|\right)\right)
$$

A similar equation as Equation 5.7 is given by Rochelle et al. (2001) and describes the ratio of $\mathrm{CO}_{2}$ equilibrium partial pressure at absorber temperature (here $p_{\mathrm{CO}_{2} \text {,ref }}^{*}$ ) to that at stripper temperature (here $p_{\mathrm{CO}_{2}}^{*}$ ).

In this work, another approach is used in which the $R$ value is estimated from regeneration pressure and temperature at the top of the stripper column. The configuration of the top of the stripper column is indicated schematically in Figure 5.1. The following assumptions are made: (i) the feed is introduced one tray below the water wash tray, (ii) temperature at the feed tray is the same as temperature of the feed itself. In this fashion, the top temperature can be calculated from a simplified enthalpy balance for the water vapour and liquid streams entering and leaving the water wash tray, and without the necessity of taking into account the solvent contributions. The contribution of $\mathrm{CO}_{2}$ entering and leaving the water wash tray is neglected as it contributes only around $2 \%$ of the net enthalpy input to that tray and results in less than $0.2 \%$ difference in the final reboiler duty calculated.

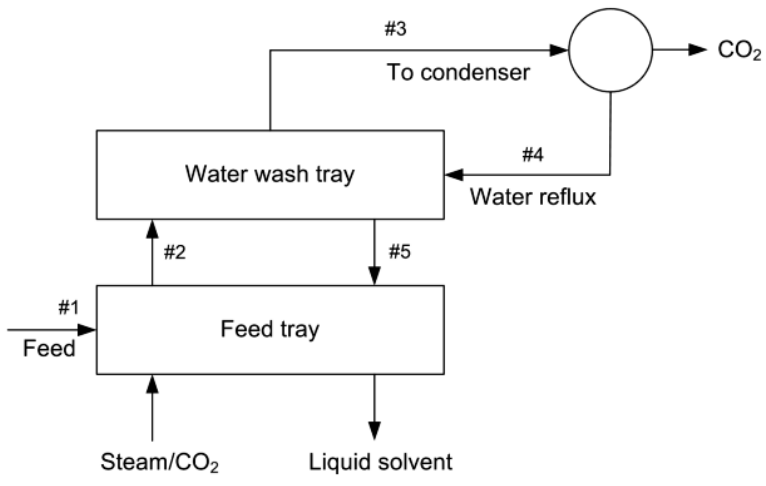

Figure 5.1: Top-section of the regenerator column

The solvent specific properties and process parameters, required as the input for the calculation method, are listed in Table 5.2. Using the input parameters presented in this table, the mass- and enthalpy balances for the top-section of the regenerator (as presented in Figure 5.1) can be calculated. In this calculation, molar balances listed in Table 5.3 are used. Note that subscripts ' $f t$ ' and ' $w t$ ' stand, respectively, for the feed-and water wash trays. The cyclic capacity, $\Delta \alpha$, is defined as the difference in the rich and lean liquid $\mathrm{CO}_{2}$ loadings. 
Table 5.2: Input parameters for the reboiler duty calculation

\begin{tabular}{ll}
\hline Solvent properties & \\
\hline Density & $\rho$ \\
Heat capacity & $C_{p}$ \\
Enthalpy of desorption & $\Delta H_{d e s, C O_{2}}$ \\
\hline Process parameters & \\
\hline Solvent concentration & $C_{m}$ \\
Mole fraction of water in the solution & $x_{\mathrm{H}_{2} O}$ \\
Rich liquid loading & $\alpha_{\text {rich }}$ \\
Lean liquid loading & $\alpha_{\text {lean }}$ \\
Reboiler temperature & $T_{\text {reb }}$ \\
Condenser temperature & $T_{\text {cond }}$ \\
Temperature approach determined by HEX & $\Delta T$ \\
Pressure drop (bottom-top of stripper) & $\Delta P$ \\
\hline
\end{tabular}

Table 5.3: Mass- and enthalpy balances for the top-section of the regenerator

\begin{tabular}{|c|c|}
\hline Feed $(\# 1)$ & Known composition \\
\hline \multirow{4}{*}{$\mathrm{CO}_{2}$ molar balance } & $\phi_{M, C O_{2}}(\# 2)=\phi_{M, A m i n e}(\# 1) \cdot \Delta \alpha$ \\
\hline & $\phi_{M, C O_{2}}(\# 3)=\phi_{M, C O_{2}}(\# 2)$ \\
\hline & $\phi_{M, C O_{2}}(\# 4)=0$ \\
\hline & $\phi_{M, \mathrm{CO}_{2}}(\# 5)=0$ \\
\hline \multirow[t]{4}{*}{ Water molar balance } & $\phi_{M, H_{2} O}(\# 2)=\phi_{M, C_{2}}(\# 3) \cdot R_{f t}$ \\
\hline & $\phi_{M, H_{2} O}(\# 3)=\phi_{M, C O_{2}}(\# 3) \cdot R_{w t}$ \\
\hline & $\phi_{M, H_{2} O}(\# 4)=\phi_{M, H_{2} O}(\# 3)$ \\
\hline & $\phi_{M, H_{2} O}(\# 5)=\phi_{M, H_{2} O}(\# 4)$ \\
\hline \multirow[t]{3}{*}{ Enthalpy balance } & $\phi_{H}(\# 2)+\phi_{H}(\# 4)=\phi_{H}(\# 3)+\phi_{H}(\# 5)$ \\
\hline & $\phi_{H}(\# i)=\phi_{M, H_{2} O}(\# i) \cdot H_{H_{2} O}^{\text {sat.vap. }}\left(P_{\text {top }}, T(\# i)\right) \cdot M_{H_{2} O}$ \\
\hline & $\phi_{H}(\# j)=\phi_{M, H_{2} 0}(\# j) \cdot H_{H_{2} O}^{\text {sat.liq. }}\left(P_{\text {top }}, T(\# j)\right) \cdot M_{H_{2} O}$ \\
\hline \multirow[t]{5}{*}{ Temperatures } & $T_{\text {feed }}=T_{\text {reb }}-\Delta T$ \\
\hline & (from enthalpy balance) \\
\hline & $T(\# 4)=T_{\text {cond }}$ \\
\hline & $T(\# 2)=T_{\text {feed }}$ \\
\hline & $T(\# 5)=T(\# 3)$ \\
\hline
\end{tabular}

The overall calculation procedure to calculate $R_{w t}$ and $R_{f t}$ now involves the following steps (where subscripts ' $b$ ' and 'top' stands for the bottom and top conditions in the column, respectively): 
1. Select reboiler temperature, $T_{r e b}$, and a lean $\mathrm{CO}_{2}$ liquid loading, $\alpha_{\text {lean }}$.

2. From VLE data at $T_{\text {reb }}$ find the reboiler $\mathrm{CO}_{2}$ equilibrium partial pressure, $p_{\mathrm{CO}_{2}, b}$, at the selected $\alpha_{\text {lean }}$.

3. The water vapour pressure at the reboiler conditions, $p_{H_{2} O, b}$, is estimated using the following equation: $p_{\mathrm{H}_{2} \mathrm{O}, b}=p_{\mathrm{H}_{2} \mathrm{O}}^{0}\left(T_{r e b}\right) \cdot x_{\mathrm{H}_{2} \mathrm{O}} \cdot \gamma$; where $x_{\mathrm{H}_{2} \mathrm{O}}$ is the mole fraction for water in the solution and $\gamma$ is the non-ideality coefficient defined as the ratio of the solution vapour pressure at zero $\mathrm{CO}_{2}$ loading, $p^{\text {vap }}$, and the vapour pressure for pure water at the reboiler temperature, $p_{\mathrm{H}_{2} \mathrm{O}}^{0}\left(T_{r e b}\right)$.

4. Calculate the total pressure at the bottom of a regenerator (maximum attainable pressure), $P_{b}$, using formula: $P_{b}=p_{\mathrm{H}_{2} \mathrm{O}, \mathrm{b}}+p_{\mathrm{CO}_{2}, b}$.

5. With pressure $P_{b}$ at the bottom and the assumed pressure drop, $\Delta P$, over the column, the operating pressure at the top (water wash- and feed trays) of the regenerator is $P_{\text {top }}=P_{w t}=P_{f t}=P_{b}-\Delta P$.

6. For the feed tray, the water vapour pressure, $p_{\mathrm{H}_{2} \mathrm{O}, \mathrm{ft}}$, is calculated via $p_{\mathrm{H}_{2} \mathrm{O}, \mathrm{ft}}=$ $p_{\mathrm{H}_{2} \mathrm{O}}^{0}\left(T_{f e e d}\right) \cdot x_{\mathrm{H}_{2} \mathrm{O}} \cdot \gamma$ and the $\mathrm{CO}_{2}$ partial pressure via $p_{\mathrm{CO}_{2}, f t}=P_{f t}-p_{\mathrm{H}_{2} \mathrm{O}, \mathrm{ft}}$. The ratio $R_{f t}$ is now $\left(p_{\mathrm{H}_{2} \mathrm{O}} / p_{\mathrm{CO}_{2}}\right)_{f t}$.

7. Use an initial guess for $T_{w t}$ (e.g. $T_{w t}=T_{\text {feed }}$ ).

8. Calculate the vapour pressure of water at the water wash tray, $p_{\mathrm{H}_{2} O, w t}$, via $p_{\mathrm{H}_{2} \mathrm{O}, w t}=p_{\mathrm{H}_{2} \mathrm{O}}^{0}\left(T_{w t}\right)$ and the $\mathrm{CO}_{2}$ partial pressure at the top using equation: $p_{\mathrm{CO}_{2}, w t}=P_{\text {top }}-p_{\mathrm{H}_{2} \mathrm{O}, w t}$. With this, $R_{w t}=\left(p_{\mathrm{H}_{2} \mathrm{O}} / p_{\mathrm{CO}_{2}}\right)_{w t}$.

9. With $R_{f t}$ and $R_{w t}$ known, the flowrate and composition of all streams can be calculated using the mass- and enthalpy balances from Table 5.3.

10. Check if the enthalpy balance over the water wash tray closes (see Table 5.3 and Figure 5.1). Adjust the value for $T_{w t}$ (in step 7 above) and repeat steps 8 and 9 until the enthalpy balance is closed.

The (minimum) $R$ value relevant to the energy requirement calculation (see Equation 5.4 ) is now the $R_{w t}$ value for the converged solution. The optimal ratio between $R$-actual and $R$-min normally depends upon an economic analysis that compares the cost of energy (which rises with rising reflux) with a number of column trays (which declines with rising reflux); and for most commercial operations it equals to 1.1 to 1.5 (de Haan and Bosch, 2007). For the present case, it is assumed that $R_{w t}$-actual $/ R_{w t}$-min $=1.2$. Hence, via Equation 5.4 , the 
contribution $Q_{v a p, H_{2} O}$ can now be calculated. In addition, the sensible heat, $Q_{\text {sens }}$, is here calculated using Equation 5.8.

$$
Q_{\text {sens }}=\frac{\rho C_{p} \Delta T}{\Delta \alpha C_{m} M_{\mathrm{CO}_{2}}}+\frac{\left(\phi_{\mathrm{H}}\left(\# 4, T_{\text {reb }}\right)-\phi_{\mathrm{H}}\left(\# 4, T_{\text {cond }}\right)\right) M_{\mathrm{H}_{2} \mathrm{O}}}{\Delta \alpha C_{m} M_{\mathrm{CO}_{2}}}
$$

In this equation not only the difference in the sensible heat between the rich and lean streams is taken into account but also the sensible heat effect associated with feeding the cold reflux condensate back to the column.

\subsection{Results and discussion}

The high volatility of (alkanol)amine-based solvents results in higher wash-up costs and environmental risks (Kohl and Nielsen, 1997; Nguyen et al., 2011); whereas, in general, salt solutions are characterized by negligible vapour pressure of the active components and thus show minimum liquid evaporation losses (Housecroft and Constable, 2010). For amino acid salts, Aronu et al. (2011) reported the vapour pressure of aqueous potassium sarcosinate solutions $\left(C_{m}=1,2,3.5,3,4,5 \mathrm{M}\right)$ at temperatures of 313, 333, 353 and 373 K. In Figure 5.2, the measured vapour-liquid equilibrium data of L-proline and sarcosine solutions at regeneration temperatures are presented. These data are compared with the $p^{\text {vap }}$ values of other aqueous $\mathrm{CO}_{2}$ absorbents. As expected, amino acid salts are characterized by lower vapour pressures as compared to amines. For amines, the following trend in increasing volatility was reported in the literature: tertiary < secondary < primary (Xu et al., 1991; Kennard et al., 1984). Nguyen et al. (2011) related volatility of amines with molecular groups and structural shapes. The volatility-structural relations for amines seem to be also applicable for amino acid salts. It was reported that amines having one or more polar groups, such as amine, hydroxyl, and ether groups, tend to be less volatile due to favourable interactions with water. Presence of one or more methyl groups in the structure contributes to non-polarity and greater volatility (e.g. AMP). As a second order effect, presence of an $\mathrm{N}-\mathrm{CH}_{3}$ contribution in a straight chained amine (e.g. sarcosine), or a $\mathrm{C}-\mathrm{CH}_{3}$ contribution in a cyclic amine, correlates to lower volatility. Finally, cyclic amines (e.g. proline) appear to be less volatile than straight chain amines (e.g. glycine).

At temperatures greater than $398 \mathrm{~K}$ an accelerated MEA degradation was reported (Movagharnejad and Akbari, 2011). The VLE apparatus and methodology applied were therefore validated using potassium salt of sarcosine. The equilibrium partial pressure of $\mathrm{CO}_{2}$ over aqueous solutions of potassium L-prolinate $\left(C_{m}=3,4 \mathrm{M}\right)$ for the $\mathrm{CO}_{2}$ partial pressure range of 3.0 to $358 \mathrm{kPa}$ and potassium sarcosinate $\left(C_{m}=3 \mathrm{M}\right)$ for $p_{\mathrm{CO}_{2}}$ ranging from 
3.3 to $253 \mathrm{kPa}$ was measured. The experiments were carried out at temperatures of 363,383 and $403 \mathrm{~K}$. The VLE curves obtained for potassium salts of sarcosine and L-proline are shown in Figures 5.3 and 5.4, respectively. Aronu et al. (2011) reported $\mathrm{CO}_{2}$ partial pressure over $3.5 \mathrm{~mol} . \mathrm{dm}^{-3}$ solutions of potassium sarcosinate for the $p_{\mathrm{CO}_{2}}$ range of $0.03-14.6 \mathrm{kPa}$ at temperatures of 313,333 and $353 \mathrm{~K}$, and for the $p_{\mathrm{CO}_{2}}$ range of $38.1-971 \mathrm{kPa}$ at temperatures of 373 and $393 \mathrm{~K}$. It was found that the VLE data from the present work for potassium sarcosinate are comparable to the data by Aronu et al. (2011). The reaction enthalpy of potassium sarcosinate solution was calculated according to Equation 5.5 and compared to the values reported by Aronu et al. (2011). At the liquid $\mathrm{CO}_{2}$ loading, $\alpha$, of 0.2 (mole $\mathrm{CO}_{2}$ per mole solvent) the enthalpy of desorption is found to be $66.3 \mathrm{~kJ} \cdot \mathrm{mol}^{-1} \mathrm{CO}_{2}$ and at $\alpha=0.4$ the enthalpy of desorption equals to $62.2 \mathrm{~kJ} \cdot \mathrm{mol}^{-1} \mathrm{CO}_{2}$. These values agree with the value of $66.7 \mathrm{~kJ} \cdot \mathrm{mol}^{-1} \mathrm{CO}_{2}$ reported at $\alpha=0.2$ for $3.5 \mathrm{~mol} \cdot \mathrm{dm}^{-3}$ solution by Aronu et al. (2011).
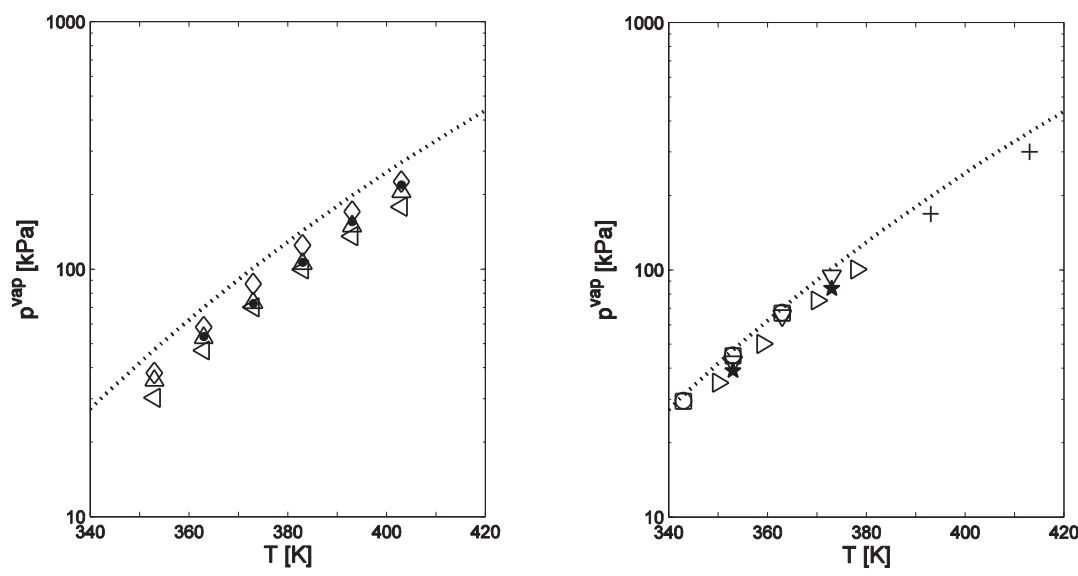

Figure 5.2: (left) Experimental results of the vapour pressure of aqueous: $\diamond, 2 \mathrm{M}$ L-prolinate; $\Delta, 3 \mathrm{M}$ L-prolinate; $\triangleleft$, 4 M L-prolinate; $\bullet, 3 \mathrm{M}$ sarcosinate. (right) Literature values of the vapour pressure of aqueous $\mathrm{CO}_{2}$ absorbents: $\star$, 3.5 M sarcosinate Aronu et al. (2011); $\triangleright$, $3.3 \mathrm{M}$ glycinate Song et al. (2011); $\square, 2.6$ M MEA Belabbaci et al. (2009); +, 3 M DEA Kennard et al. (1984); $\nabla$, 2.6 M MDEA Xu et al. (1991); O, 2.3 M AMP Belabbaci et al. (2010). Dotted line stands for water by Popiel and Wojtkowiak (1998)

At a certain $\alpha$ value, an increase in the system temperature results in higher $\mathrm{CO}_{2}$ partial pressure; which is common for $\mathrm{CO}_{2}-($ alkanol $)$ amine- $\mathrm{H}_{2} \mathrm{O}$ systems. For both amino acids, the dependence of $\mathrm{CO}_{2}$ partial pressure on temperature and $\mathrm{CO}_{2}$ liquid loading in the temperature range studied has been expressed by Equation 5.9, where $a_{0}-a_{5}$ are constants (see Table 5.4). The average relative deviation between the experimental data and the values 
from the fits are 7.6 and $2.2 \%$ for 3 and $4 \mathrm{~mol} \cdot \mathrm{dm}^{-3}$ L-prolinate solutions, respectively, and $2.8 \%$ for sarcosinate solution.

$$
\ln p_{C O_{2}}=a_{0}+a_{1} \alpha+a_{2} T+a_{3} \alpha^{2}+a_{4} \alpha T+a_{5} T^{2}
$$

Table 5.4: Constants $a_{0}-a_{5}$ in Equation 5.9

\begin{tabular}{lcccccc}
\hline Solvent & $a_{0}$ & $a_{1}$ & $a_{2} \times 10^{-2}$ & $a_{3}$ & $a_{4} \times 10^{-3}$ & $a_{5} \times 10^{-5}$ \\
\hline Potassium L-prolinate, 3 M solution & 7.40 & 13.08 & -7.89 & 10.95 & -31.27 & 16.17 \\
Potassium L-prolinate, 4 M solution & 17.64 & 2.834 & -13.62 & 21.36 & -20.38 & 24.79 \\
Potassium sarcosinate, 3 M solution & 11.51 & 16.57 & -11.57 & 5.084 & -24.31 & 22.12 \\
\hline
\end{tabular}

The effect of amino acid salt concentration on the absorption capacity of $\mathrm{CO}_{2}$ for potassium L-prolinate solutions was also investigated - see Figure 5.4. Generally, if the main path of $\mathrm{CO}_{2}$ absorption is the formation of a carbamate (primary and secondary amines), the absorption equilibria are less dependent on the solvent concentration (up to a certain $\mathrm{CO}_{2}$ liquid loading). On the other hand, if the bicarbonate formation dominates (e.g. for tertiary and some sterically hindered primary and secondary amines), the absorbent concentration significantly influences the VLE behaviour of the system (Oexmann and Kather, 2010). This latter pathway is, however, kinetically less favourable than the formation of a carbamate. For L-prolinate, no significant reduction in $\mathrm{CO}_{2}$ solubility in $4 \mathrm{~mol} \cdot \mathrm{dm}^{-3}$ solution, when compared with the results for $3 \mathrm{~mol} \cdot \mathrm{dm}^{-3}$ solution, is found up to $\alpha \approx 0.35\left(\mathrm{~mole} \mathrm{CO}_{2}\right.$ per mole solvent). This loading increases to (approximately) 0.40 and 0.46 (mole $\mathrm{CO}_{2}$ per mole solvent) as the absorption temperature decreases to 383 and $363 \mathrm{~K}$, respectively. 


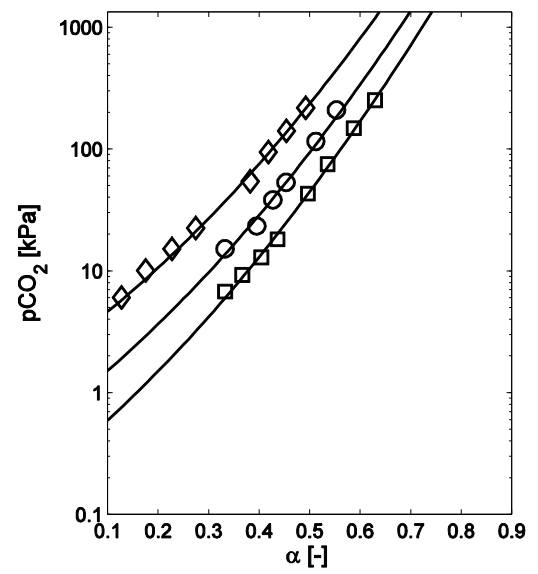

Figure 5.3: Experimental results of the $\mathrm{CO}_{2}$ equilibrium partial pressure over $3 \mathrm{M}$ solution of potassium sarcosinate. $\square, T=363 \mathrm{~K} ; \mathrm{O}, T=383 \mathrm{~K} ; \diamond, T=403 \mathrm{~K}$; - , calculated by Equation 5.9
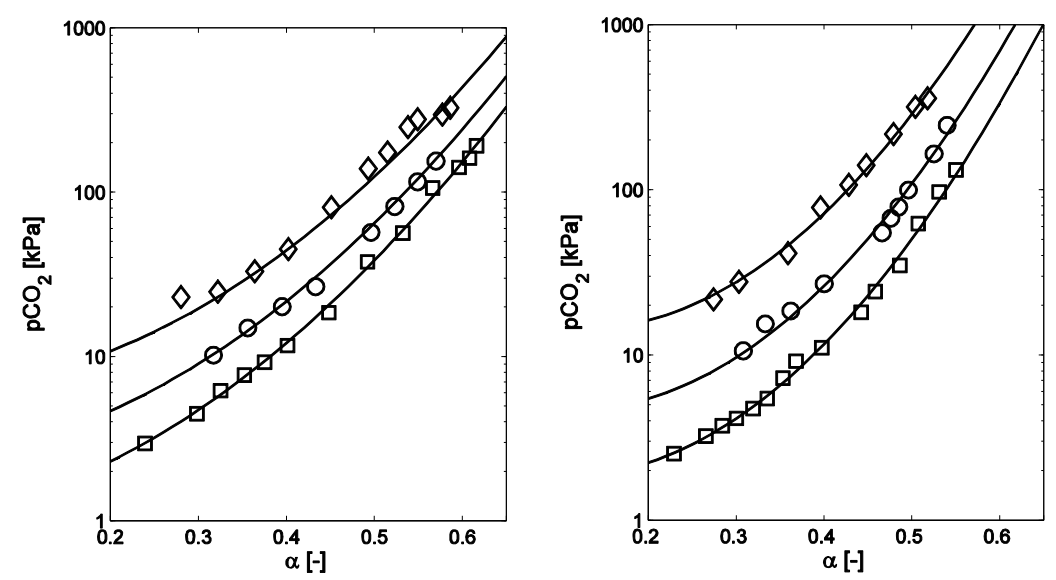

Figure 5.4: Experimental results of the $\mathrm{CO}_{2}$ equilibrium partial pressure over potassium salt of L-proline: (left) 3 M solution; (right) 4 M solution. $\square, T=363 \mathrm{~K} ; \mathrm{O}, T=383 \mathrm{~K} ; \diamond, T=403 \mathrm{~K}$; 一, calculated by Equation 5.9

In a recent version of the ASPEN process simulator (Aspen Plus v8.o) a working example of $\mathrm{CO}_{2}$ absorption in 4.5 M MEA solution is available, based on a full electrolyte-NRTL column model for absorber and stripper. The results for the stripper were compared with the method developed in this work for 5 M MEA solution. The reboiler duty found with the method described above is in good agreement with the ASPEN simulation $\left(5.18 \mathrm{MJ} \cdot \mathrm{kg}^{-1} \mathrm{CO}_{2}\right.$ (this work) vs. $5.25 \mathrm{MJ} \cdot \mathrm{kg}^{-1} \mathrm{CO}_{2}$ (Aspen)) and also distributions of the three energy 
components in Equation 5.1 are quite similar, see Figure A.1 in the Appendix. The $R$ value for the water wash tray in the Aspen simulation equals 2.20 whereas a value of 1.86 is found with the present method. The $R$ value for the feed tray in the Aspen simulation equals 2.38 vs. 2.33 as found by the current method. More information can be found in the Appendix.

Carbon dioxide capture process in aqueous solutions of (alkanol)amines has been simulated and studied under different process conditions in a number of publications (e.g. Sakwattanapong et al., 2005; Tobiesen et al., 2005; Warudkar et al., 2013); where several process parameters have been varied over a given span to study their effect on the $\mathrm{CO}_{2}$ removal and the reboiler duty. It has been pointed out that some major energy savings can be obtained by optimizing the $\mathrm{CO}_{2}$ liquid loading level in the amine system. Therefore, this factor was studied for $3 \mathrm{~mol} \cdot \mathrm{dm}^{-3}$ aqueous solution of potassium L-prolinate by keeping the lean solvent loading constant at the value of 0.262 and increasing the rich loading. The input parameters as reported in Table A.3 in the Appendix were applied. Equation 5.9 was used to calculate the VLE data of the system. The results of this study are presented in Table $5 \cdot 5$.

Table 5.5: Calculated values of the reboiler duty vs. $\alpha_{\text {rich }}$ for potassium L-prolinate using input parameters reported in Table A.3: $C_{m}=3 \mathrm{M} ; T_{\text {reb }}=403 \mathrm{~K} ; \alpha_{\text {lean }}=0.262$ (mole $\mathrm{CO}_{2}$ per mole solvent)

\begin{tabular}{cc}
\hline $\begin{array}{c}\alpha_{\text {rich }} \\
{[-]}\end{array}$ & $\begin{array}{c}Q_{\text {reb }} \\
{\left[\mathrm{MJ} \cdot \mathrm{kg}^{-1} \mathrm{CO}_{2}\right]}\end{array}$ \\
\hline 0.400 & 6.26 \\
0.425 & 5.94 \\
0.450 & 5.71 \\
0.475 & 5.53 \\
0.500 & 5.39 \\
0.525 & 5.28 \\
0.550 & 5.19 \\
0.586 & 5.08 \\
\hline
\end{tabular}

It is apparent that at a given lean $\mathrm{CO}_{2}$ loading, a reduction in the rich $\mathrm{CO}_{2}$ loading leads to an increase in the reboiler duty. For a theoretical maximum rich solution loading of 0.586 (mole $\mathrm{CO}_{2}$ per mole solvent), represented by an equilibrium with the feed gas at the absorber bottom conditions, a reboiler duty of $5.08 \mathrm{MJ} \cdot \mathrm{kg}^{-1} \mathrm{CO}_{2}$ is calculated. Since this theoretical maximum cannot be attained in practical equipment, a " $75-80 \%$ approach to equilibrium" is often assumed in the design of the amine plants (Kohl and Nielsen, 1997). For the alpha rich of 0.465 a reboiler duty of at least $5.60 \mathrm{MJ} \cdot \mathrm{kg}^{-1} \mathrm{CO}_{2}$ is required by the system, using the conditions from Table A.3. As presented in Figure A.2 (in the Appendix), high values of the sensible heat and the heat of vaporization of water are the main reason of 
high regeneration heat of L-prolinate; of which $Q_{\text {sens }}$ corresponds to $30.8 \%, Q_{v a p, H_{2} O}$ to $45.3 \%$, and $Q_{d e s, \mathrm{CO}_{2}}$ to $24.0 \%$.

The approach by Oexmann and Kather was used to calculate the $R$ value and further the reboiler duty of potassium L-prolinate solution. For the calculated ratio of 2.9 the reboiler duty of $5.64 \mathrm{MJ} \cdot \mathrm{kg}^{-1} \mathrm{CO}_{2}$ was found. The $Q_{\text {reb }}$ and $R$ values thus calculated are around $1 \%$ higher than the values obtained by the current method. It was observed that the $R$ values obtained by the Oexmann and Kather method are sensitive to the value of enthalpy of reaction inserted to their formula (Equation 5.7). For instance, when $\Delta H_{d e s, \mathrm{CO}_{2}}$ is increased by $10 \%$ (which is probably within the range of experimental error) to $65 \mathrm{~kJ} \cdot \mathrm{mol}^{-1}$, the $R$ value increases to 4.2. This inconvenience is eliminated in the model developed in the present work. In addition, the current method allows studying the reboiler duty of the considered acid gas absorption process for different process conditions.

The inlet temperature of the rich solution to the stripper column is determined by a performance of the rich-lean cross-flow heat exchanger. The minimum acceptable temperature approach of $10-15 \mathrm{~K}$ is usually used in the design of the amine-based $\mathrm{CO}_{2}$ absorption systems but with the use of more modern plate exchangers a $\Delta T$ of less than $5 \mathrm{~K}$ can be achieved (Tobiesen et al. 2005). The predicted change of the reboiler duty and the three energy contributions for potassium L-prolinate with $\Delta T$ is illustrated in Figure 5.5. The rich liquid loading was fixed to 0.465 (mole $\mathrm{CO}_{2}$ per mole solvent). No reduction in the reboiler duty with a decreasing $\Delta T$ value is found. Instead an optimum of $5.21 \mathrm{MJ} \cdot \mathrm{kg}^{-1} \mathrm{CO}_{2}$ at $\Delta T$ equal to $15 \mathrm{~K}$ is reached. This finding is contrary to the conclusion of Barchas and Davis (1992) who stated generally that with a more efficient cross-flow heat exchanger much less energy for stripping $\mathrm{CO}_{2}$ is needed. Finally, an influence of the pressure drop along the stripper column, $\Delta P$, on the reboiler duty was investigated. As $\Delta P$ increases from a zero pressure drop to $0.1 \mathrm{kPa}$ the energy consumption of the system increases by $7.7 \%$ from 5.17 to $5.50 \mathrm{MJ} \cdot \mathrm{kg}^{-1} \mathrm{CO}_{2}$, and is further increased by $21.6 \%$ as $\Delta P$ goes up to $0.3 \mathrm{kPa}$. A complete optimization of the system is, however, not pursued in this work. 


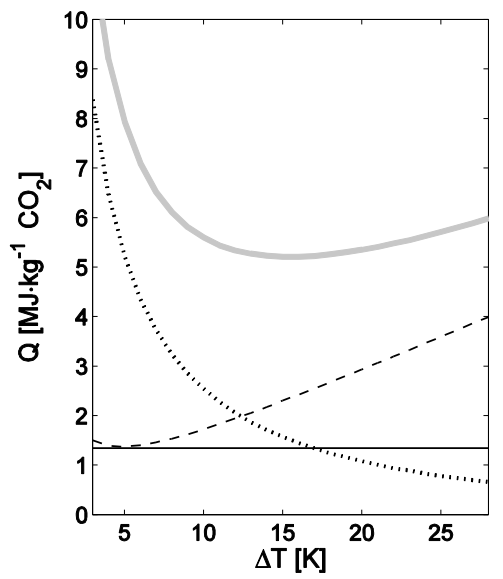

Figure 5.5: Calculated values of the total energy requirements (reboiler duty) and individual energy contributions vs. $\Delta T$ for potassium L-prolinate using input parameters reported in Table A.3: $C_{m}=3 \mathrm{M} ; T_{\text {reb }}=403 \mathrm{~K} ; \alpha_{\text {lean }}=0.262$ (mole $\mathrm{CO}_{2}$ pre mole solvent). - , reboiler duty; ----, sensible heat; - , heat of desorption; ….., heat of evaporation

In general, aqueous amino acid salt solutions have slightly higher desorption energy requirements than, e.g., the industry standard MEA. Erga et al. (1995) performed the equilibrium and pilot plant tests using aqueous solutions of MEA, MDEA-piperazine mixture, and potassium salts of sarcosine and glycine. For amino acids, the operational conditions used were as follows: a 6.0 vol $\% \mathrm{CO}_{2}$ gas stream at the inlet of the absorber, $\mathrm{CO}_{2}$ absorption temperature of $313 \mathrm{~K}, 4 \mathrm{M}$ solutions, stripping temperature of $413 \mathrm{~K}, \Delta T$ set to 10 $K$. In terms of the reboiler heat demand, the amino acid systems were found to be less competitive than MEA solution. The reboiler duties for stripping $\mathrm{CO}_{2}$ from aqueous potassium salts of glycine and sarcosine were 6.05 and $5.77 \mathrm{MJ} \cdot \mathrm{kg}^{-1}$ of $\mathrm{CO}_{2}$, respectively. In another comparison, Song et al. (2008) calculated the regeneration energy for $30 \mathrm{wt} \%$ aqueous solutions of MEA and for sodium salt solutions of glycine. Other assumptions made in that study included a rich liquid loading of 0.4 , a temperature difference between top and bottom of the stripper of $50 \mathrm{~K}$ and a stripping temperature of $393 \mathrm{~K}$. It was reported that the heat demand for glycinate $\left(Q_{r e b}=5.74 \mathrm{MJ} \cdot \mathrm{kg}^{-1} \mathrm{CO}_{2}\right)$ is $17 \%$ higher than that for the MEA system $\left(Q_{\text {reb }}=4.75 \mathrm{MJ} \cdot \mathrm{kg}^{-1} \mathrm{CO}_{2}\right)$ under the same conditions.

Also in this work, for potassium salt of L-proline the calculated reboiler duty, $Q_{r e b}$, is higher than the value found for the MEA system. The results are in line with the numbers reported in open literature for other amino acid salts. 


\subsection{Conclusions}

Vapour-liquid equilibrium data for $\mathrm{CO}_{2}$-saturated and $\mathrm{CO}_{2}$-free potassium L-prolinate solutions were obtained at the stripper operating conditions. The experimental VLE data at regeneration conditions were used to calculate the reboiler duty for an absorption-desorption process. This heat duty is calculated as the sum of the desorption enthalpy of $\mathrm{CO}_{2}$, the sensible heat and the heat of vaporization. A new method to determine the latter contribution was used and tested against a full Electrolyte-NRTL rigorous column model. Like for other amino acid salt solutions, the energy required for stripping $\mathrm{CO}_{2}$ from aqueous solutions of L-proline is somewhat higher than that for the $5 \mathrm{M}$ MEA reference system. With the new method, the influence of a few process parameters on the calculated reboiler duty of potassium L-prolinate was investigated, showing, e.g., an optimum temperature approach, $\Delta T$, of $15 \mathrm{~K}$ for the lean-rich heat exchanger. The specific reboiler duty reduces with increasing cyclic capacity of the amino acid salt solution. Hence, an increase in the alpha rich by precipitation during absorption may result in further energy savings in amino acid salt-based $\mathrm{CO}_{2}$ absorption systems. 


\section{Nomenclature}

\begin{tabular}{|c|c|}
\hline$C_{p}$ & heat capacity $\left[\mathrm{kJ} \cdot \mathrm{kg}^{-1} \cdot \mathrm{K}^{-1}\right]$ \\
\hline$\Delta \mathrm{H}_{\text {des, } \mathrm{CO}_{2}}$ & heat of reaction $\left[\mathrm{kJ} \cdot \mathrm{mol}^{-1}\right]$ \\
\hline $\mathrm{H}_{\mathrm{H}_{2} \mathrm{O}}^{\text {sat.liq. }}$ & specific enthalpy of boiling water $\left[\mathrm{kJ} \cdot \mathrm{kg}^{-1}\right]$ \\
\hline $\mathrm{H}_{\mathrm{H}_{2} \mathrm{O}}^{\text {sat.vap. }}$ & specific enthalpy of saturated steam $\left[\mathrm{kJ} \cdot \mathrm{kg}^{-1}\right]$ \\
\hline$\Delta \mathrm{H}_{\text {vap }, \mathrm{H}_{2} \mathrm{O}}$ & heat of water evaporation $\left[\mathrm{kJ} \cdot \mathrm{kg}^{-1}\right]$ \\
\hline $\mathrm{M}_{\mathrm{CO}_{2}}$ & molar mass of carbon dioxide $\left[\mathrm{kg} \cdot \mathrm{mol}^{-1}\right]$ \\
\hline$M_{\mathrm{H}_{2} \mathrm{O}}$ & molar mass of water $\left[\mathrm{kg} \cdot \mathrm{mol}^{-1}\right]$ \\
\hline$Q_{\text {sens }}$ & sensible heat $\left[\mathrm{MJ} \cdot \mathrm{kg}^{-1} \mathrm{CO}_{2}\right]$ \\
\hline$Q_{v a p, H_{2} O}$ & heat of evaporation $\left[\mathrm{M} J \cdot \mathrm{kg}^{-1} \mathrm{CO}_{2}\right]$ \\
\hline$Q_{d e s, \mathrm{CO}_{2}}$ & heat of desorption $\left[\mathrm{MJ} \cdot \mathrm{kg}^{-1} \mathrm{CO}_{2}\right]$ \\
\hline$Q_{r e b}$ & reboiler duty $\left[\mathrm{MJ} \cdot \mathrm{kg}^{-1} \mathrm{CO}_{2}\right]$ \\
\hline$P$ & pressure $[\mathrm{kPa}]$ \\
\hline$T$ & temperature $[\mathrm{K}]$ \\
\hline$\alpha$ & loading [mole $\mathrm{CO}_{2}$ per mole solvent] \\
\hline$\Phi_{M}$ & molar flow $\left[\mathrm{mol} \cdot \mathrm{s}^{-1}\right]$ \\
\hline$\Phi_{H}$ & enthalpy flow $\left[\mathrm{kJ} \cdot \mathrm{s}^{-1}\right]$ \\
\hline$\rho$ & density $\left[\mathrm{kg} \cdot \mathrm{m}^{-3}\right]$ \\
\hline
\end{tabular}




\section{Appendix}

The energy required for stripping $\mathrm{CO}_{2}$ from aqueous $5 \mathrm{M}$ MEA solution was calculated with the model developed in this work and compared with the data obtained in the working Aspen Plus Example (Aspen Plus v8.o). The system parameters utilized in the calculations are listed in Table A.1. For the current method, the density of solution was taken from Amundsen et al. (2009) and the heat capacity was from Song et al. (2008). The enthalpy of desorption and the $\mathrm{CO}_{2}$ equilibrium partial pressure were calculated using the VLE model by Majchrowicz and Brilman (2012); see also Chapter 3.

The contributions of the three energy components in Equation 5.1 to the reboiler duty as obtained by the two methods are reported in Table A.2 and illustrated in Figure A.1. Individually all the three contributions of regeneration energy and the total regeneration energy as obtained by the model are in a relatively good agreement with the data generated by the Aspen process simulation software. Within the Aspen working example an assumption of a zero pressure drop over the column is made. When this assumption is introduced to the model then $Q_{\text {reb }}$ reduces from 5.18 to $4.92 \mathrm{MJ} \cdot \mathrm{kg}^{-1} \mathrm{CO}_{2}$.

Table A.r: System parameters for the reboiler duty calculation - MEA case

\begin{tabular}{ccc}
\hline Parameter & this work & Aspen \\
\hline$\rho\left[\mathrm{kg} \cdot \mathrm{m}^{-3}\right]$ & 954 & (not reported) \\
$C_{p}\left[\mathrm{~kJ} \cdot \mathrm{kg}^{-1} \cdot \mathrm{K}^{-1}\right]$ & 4.14 & (not reported) \\
$\Delta H_{\text {des }, \mathrm{CO}_{2}}\left[\mathrm{~kJ} \cdot \mathrm{mol}^{-1} \mathrm{CO}_{2}\right]$ & 100 & (not reported) \\
$C_{m}\left[\mathrm{~mol} \cdot \mathrm{dm}^{-3}\right]$ & 5.0 & 4.5 \\
$\alpha_{\text {rich }}\left[\right.$ mole $\mathrm{CO}_{2}$ per mole solvent $]$ & 0.384 & 0.384 \\
$\alpha_{\text {lean }}\left[\right.$ mole $\mathrm{CO}_{2}$ per mole solvent $]$ & 0.262 & 0.262 \\
$T_{\text {reb }}[\mathrm{K}]$ & 392.5 & 392.5 \\
$T_{\text {cond }}[\mathrm{K}]$ & 291.2 & 291.2 \\
$\Delta T[\mathrm{~K}]$ & 6.5 & 6.5 \\
$\Delta P[\mathrm{kPa}]$ & 0.1 & 0.0 \\
\hline & $R=1.2 \times R-\min$ \\
\hline
\end{tabular}




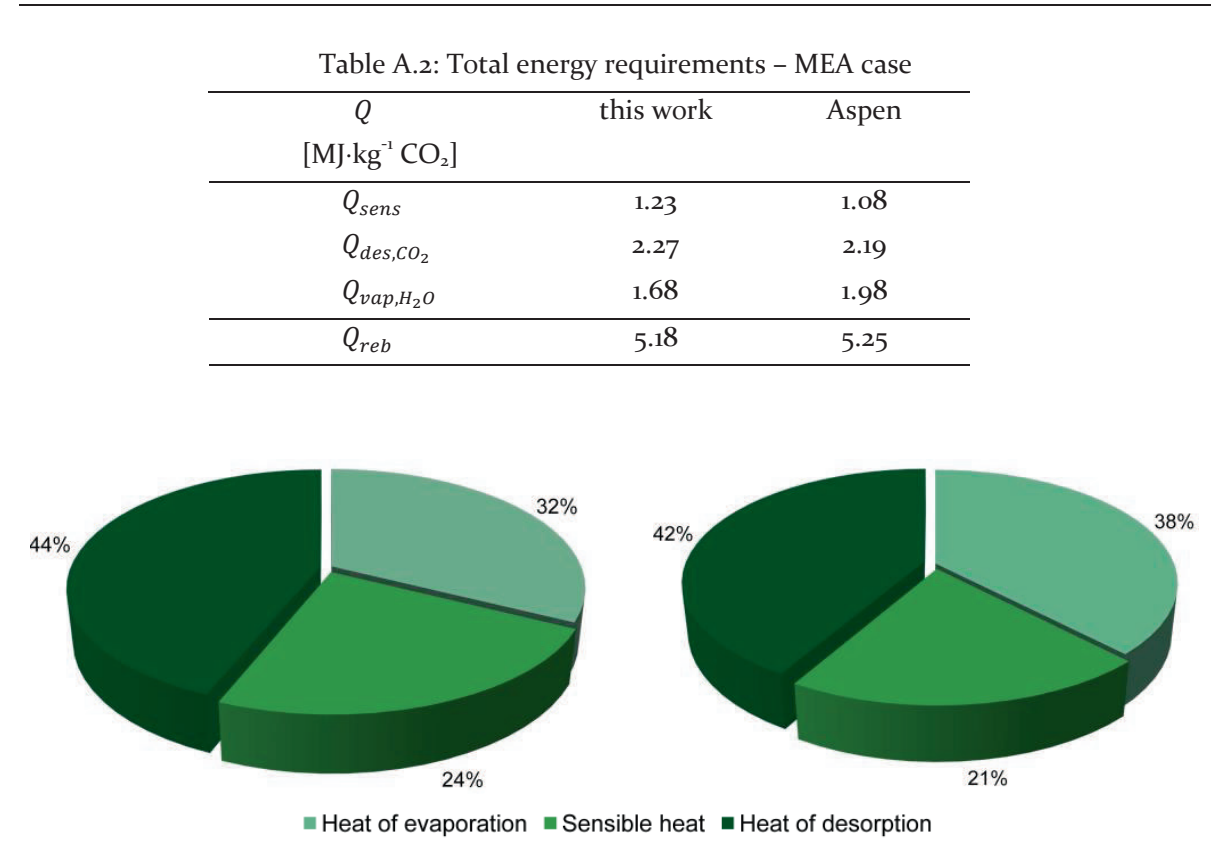

Figure A.1: Heat contributions to the reboiler duty for the MEA case: (left) calculated by the model $\left(Q_{r e b}=5.18 \mathrm{MJ} \cdot \mathrm{kg}^{-1} \mathrm{CO}_{2}\right)$, (right) calculated by the Aspen process simulator $\left(Q_{\text {reb }}=5.25 \mathrm{MJ} \cdot \mathrm{kg}^{-1} \mathrm{CO}_{2}\right)$

The energy requirements for stripping $\mathrm{CO}_{2}$ from aqueous $3 \mathrm{M}$ potassium L-prolinate solution were calculated with the use of the current method. It was assumed that the flue gas enters the absorber column bottom with $\mathrm{CO}_{2}$ partial pressure of $12 \mathrm{kPa}$. The inlet temperature of a solution to the absorber column was assumed to be $313 \mathrm{~K}$. The input parameters in Table A.3 were used in the calculations; except for setting the rich $\mathrm{CO}_{2}$ liquid loading to 0.465 (mole $\mathrm{CO}_{2}$ per mole solvent), which reflects an assumption of $79.3 \%$ of the equilibrium loading. This assumed degree of the solution saturation with $\mathrm{CO}_{2}$ is the same as that applied by the working Aspen Plus Example for the MEA solvent. The density of amino acid salt solution was taken from van Holst et al. (2008). Due to lack of experimental data, the heat capacity of $3.35 \mathrm{~kJ} \cdot \mathrm{kg}^{-1} \cdot \mathrm{K}^{-1}$ as reported by Erga et al. (1995) for aqueous potassium salts of sarcosine and glycine was used also for L-prolinate salt. Equation 5.6 was used to calculate the enthalpy of desorption of $\mathrm{CO}_{2}$ from L-prolinate solution. The contributions of the three energy components (see Equation 5.1) to the total energy required by the amino acid salt are shown in Table A.4 and Figure A.2. 
Amino Acid SAltS For CARbon Dioxide CAPTURE - EVAluATING L-ProlinAtE AT Desorber CONDITIONS

Table A.3: System parameters for the reboiler duty calculation - potassium L-prolinate

\begin{tabular}{cc}
\hline Parameter & \\
\hline$\rho\left[\mathrm{kg} \cdot \mathrm{m}^{-3}\right]$ & 1116 \\
$C_{p}\left[\mathrm{~kJ} \cdot \mathrm{kg}^{-1} \cdot \mathrm{K}^{-1}\right]$ & 3.35 \\
$\Delta H_{\text {des,CO }}\left[\mathrm{kJ} \cdot \mathrm{mol}^{-1} \mathrm{CO}_{2}\right]$ & 59 \\
$C_{m}\left[\mathrm{~mol} \cdot \mathrm{dm}^{-3}\right]$ & 3.0 \\
$\alpha_{\text {rich }}\left[\right.$ mole $\mathrm{CO}_{2}$ per mole solvent $]$ & $0.400-0.586$ \\
$\alpha_{\text {lean }}\left[\right.$ mole $\mathrm{CO}_{2}$ per mole solvent $]$ & 0.262 \\
$T_{\text {reb }}[\mathrm{K}]$ & 403.2 \\
$T_{\text {cond }}[\mathrm{K}]$ & 323.2 \\
$\Delta T[\mathrm{~K}]$ & 10 \\
$\Delta P[\mathrm{kPa}]$ & 0.1 \\
\hline
\end{tabular}

Table A.4: Total energy requirements - potassium L-prolinate

\begin{tabular}{cc}
\hline & this work \\
{$\left[\mathrm{MJ} \cdot \mathrm{kg}^{-1} \mathrm{CO}_{2}\right]$} & \\
\hline$Q_{\text {sens }}$ & 1.72 \\
$Q_{\text {des }, \mathrm{CO}_{2}}$ & 1.34 \\
$Q_{\text {vap }, \mathrm{H}_{2} \mathrm{O}}$ & 2.54 \\
\hline$Q_{\text {reb }}$ & 5.60 \\
\hline
\end{tabular}

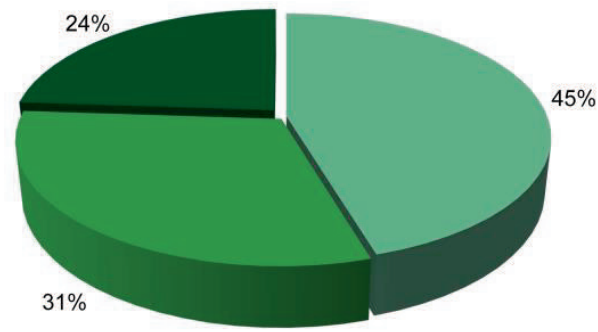

= Heat of evaporation $\backsim$ Sensible heat $\square$ Heat of desorption

Figure A.2: Heat contributions to the reboiler duty for potassium L-prolinate $\left(Q_{r e b}=5.60 \mathrm{MJ} \cdot \mathrm{kg}^{-1}\right)$ 


\section{Bibliography}

Abu Zahra, M., 2009. Carbon dioxide capture from flue gas, development and evaluation of existing and novel process concepts. Ph.D. Thesis, TU Delft, The Netherlands

Aronu, U.E., Hessen, E.T., Haug-Warberg, T., Hoff, K.A., Svendsen, H.F., 2011. Vapor-liquid equilibrium in amino acid salt: experiments and modelling. Chemical Engineering Science 66, 21912198

Barchas, R., Davis, R. 1992. The Kerr-McGee/Abb Lumnus Crest technology for the recovery of $\mathrm{CO}_{2}$ from stack gases. Energy Conversion and Management 33, 333-340

Belabbaci, A., Razzouk, A., Mokbel, I., Jose, J., Negadi, L., 2009. Isothermal vapor-liquid equilibria of (monoethanolamine + water) and (4-methylmorpholine + water) binary systems at several temperatures. Journal of Chemical Engineering Data 54, 2312-2316

Belabbaci, A., Ahmed, N.C.B., Mokbel, I., Negadi, L., 2010. Investigation of the isothermal (vapor + liquid) equilibria of aqueous 2-amino-2-methyl-1-propanol (AMP), N-benzylethanolamine, or 3dimethylamino-1-propanol solutions at several temperatures. The Journal of Chemical Thermodynamics 42, 1158-1162

Erga, O., Juliussen, O., Lidal, H., 1995. Carbon dioxide recovery by means of aqueous amines. Energy Conversion and Management 36, 387-392

Housecroft, C.E., Constable, E.C., 2010. Chemistry: an introduction to organic, inorganic and physical chemistry: $4^{\text {th }}$ Edition. Harlow Prentice Hall

Van Holst, J., Kersten S.R.A., Hogendoorn, K.J. 2008. Physicochemical properties of several aqueous amino acid salts. Journal of Chemical Engineering Data 53, 1286-1291

Kennard, M.L., Meisen, A., 1984. Solubility of carbon dioxide in aqueous diethanolamine solutions at elevated temperatures and pressures. Journal of Chemical and Engineering Data 29, 309-312

Knuutila, H., Aronu, U.E., Kvamsdal, H.M., Chikukwa, A., 2011. Post combustion $\mathrm{CO}_{2}$ capture with an amino acid salt. Energy Procedia 4, 1550-1557

Kohl, A.L., Nielsen, R.B., 1997. Gas Purification: $5^{\text {th }}$ Edition. Gulf Publishing Company, Houston Kumar, P.S., 2002. Development and design of membrane gas absorption processes. Ph.D. Thesis, University of Twente, The Netherlands

Kumełan, J., Pérez-Salado Kamps, Á., Maurer, G., 2010. Solubility of $\mathrm{CO}_{2}$ in aqueous solutions of methionine and in aqueous solutions of $\left(\mathrm{K}_{2} \mathrm{CO}_{3}\right.$ and methionine). Industrial and Engineering Chemistry Research 49, 3910-3918

Lee, J.H., Kim, J.H., Lee, I.Y., Jang, K.R., Shim, J.G., 2010. Bench scale carbon dioxide recovery from the flue gas by monoethanolamine. Journal of Chemical Engineering of Japan 43, 720-726 
Majchrowicz, M.E., Brilman, D.W.F, 2012. Solubility of $\mathrm{CO}_{2}$ in aqueous potassium L-prolinate solutions - absorber conditions. Chemical Engineering Science 72, 35-44

Movagharnejad, K., Akbari, A., 2011. Simulation of $\mathrm{CO}_{2}$ capture process. World Academy of Science, Engineering and Technology 58, 238-242

Nguyen, T., Hilliard, M., Rochelle, G., 2011. Volatility of aqueous amines in $\mathrm{CO}_{2}$ capture. Energy Procedia 4, 1624-1630

Oexmann, J., Kather, A., 2010. Minimising the regeneration heat duty of post-combustion $\mathrm{CO}_{2}$ capture by wet chemical absorption: the misguided focus on low heat of absorption solvents. International Journal of Greenhouse Gas Control 4, 36-43

Perry, R.H., Green, D.W., 1997. Perry's Chemical Engineers' Handbook: $7^{\text {th }}$ Edition. McGraw-Hill Popiel, C.O., Wojtkowiak, J., 1998. Simple formulas for thermophysical properties of liquid water for heat transfer calculations (from $0^{\circ} \mathrm{C}$ to $150^{\circ} \mathrm{C}$ ). Heat Transfer Engineering 19, 87-101

Portugal, A.F., Souse, J.M., Magalhães, F.D., Mendes, A., 2009. Solubility of carbon dioxide in aqueous solutions of amino acid salts. Chemical Engineering Science 64, 1993-2002

Rochelle, G.T., Bishnoi, S., Chi, S., Dang, H., Santos, J., 2001. Research needs for $\mathrm{CO}_{2}$ capture from flue gas by aqueous absorption/stripping. Final Report. University of Texas, Austin

Sakwattanapong, R., Aroonwilas, A., Veawab, A., 2005. Behavior of reboiler heat duty for $\mathrm{CO}_{2}$ capture plants using regenerable single and blended alkanolamines. Industrial and Engineering Chemistry Research 44, 4465-4473

Song, H.J., Lee, S., Maken, S., Park, J.J., Park, J.W., 2006. Solubilities of carbon dioxide in aqueous solutions of sodium glycinate. Fluid Phase Equilibria 246, 1-5.

Song, H.J., Lee, S., Park, K., Lee, J., Spah, D.C., Park, J.W., Filburn, T.P., 2008. Simplified estimation of regeneration energy of $30 \mathrm{wt} \%$ sodium glycinate solution for carbon dioxide absorption. Industrial and Engineering Chemistry Research 47, 9925-9930

Song, H.J., Lee, M.G., Kim, H., Gaur, A., Park, J.W., 2011. Density, viscosity, heat capacity, surface tension, and solubility of $\mathrm{CO}_{2}$ in aqueous solutions of potassium serinate. Journal of Chemical and Engineering Data 56, 1371-1377

Tobiesen, F.A., Svendsen, H.F., Hoff, K.A., 2005. Desorber energy consumption amine based absorption plants. International Journal of Green Energy 2, 201-215

Turlington, N.L., McKetta J.J., 1961. The compressibility of carbon dioxide and nitrous oxide at low pressures. American Institute of Chemical Engineers Journal 2, 336-337

Warudkar, S.S., Cox, K.R., Wong, M.S., Hirasaki, G.J., 2013. Influence of stripper operating parameters on the performance of amine absorption systems for post-combustion capture, Part 1: High pressure strippers. International Journal of Greenhouse Gas Control 16, 342-350 


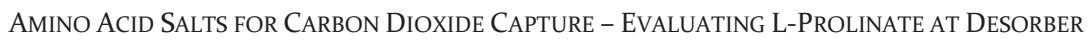
CONDITIONS

Xu, S., Qing, S., Zhen, Z., Zhang, Ch., Carroll, J.J., 1991. Vapor pressure measurements of aqueous N-methyldiethanolamine solutions. Fluid Phase Equilibria 67, 197-201 



\section{Chapter 6}

\section{General Discussion}

The current work was a part of a larger effort within the Dutch CCS CATO program project with the aim of assessing new reactive solvents based on amino acid salts for $\mathrm{CO}_{2}$ removal from the industrial gas streams. In the early stage of the project, a series of non-volatile aqueous solutions of amino acid salts (among which taurine, sarcosine, $\beta$-alanine, L-proline, DL-methionine and 6-aminohexanoic acid) were selected and screened for their $\mathrm{CO}_{2}$ absorption kinetics (van Holst et al., 2009), $\mathrm{p} K_{a}$ values (Hamborg et al., 2007) and diffusivities (Hamborg et al., 2008). In this thesis, these $\mathrm{CO}_{2}$ absorbents were evaluated for their acid gas absorption-desorption potential and their precipitation behaviour. Based on the results of the screening work, the (alkaline salt of) imino acid L-proline was selected for further investigation. For this solvent, the physico-chemical properties and kinetics of $\mathrm{CO}_{2}$ absorption were determined as well as the $\mathrm{CO}_{2}$ absorption equilibria at various conditions. A concentration-based vapour-liquid equilibrium (VLE) model was developed to describe $\mathrm{CO}_{2}$ absorption capacity at different absorption temperatures and $\mathrm{CO}_{2}$ partial pressures of the single acid gas-amine process. This model was used to calculate the equilibrium constant of the carbamate hydrolysis of L-prolinate. In addition, an estimation method was developed to calculate the energy consumption for solvent regeneration (reboiler duty), utilizing a new approach to determine the $\mathrm{H}_{2} \mathrm{O}: \mathrm{CO}_{2}$ overhead ratio in the regenerator column. This method allows studying the reboiler duty of the considered acid gas absorption process under a range of different conditions and can be used for a preliminary screening of new solvent systems.

Aqueous solutions of amino acids react with $\mathrm{CO}_{2}$ by the carbamate formation. The degree of hydrolysis of the carbamate to form bicarbonate ions and free reactant is generally related to its chemical stability, reactant concentration and $\mathrm{pH}$ of a solution. As found in the present work, L-prolinate as $\mathrm{CO}_{2}$ solvent exhibits higher rates of the carbamate formation compared to other (alkanol)amines, which was confirmed by the analysis of equilibrium concentration profiles generated by the VLE model. The carbamate species formed in the system are relatively stable towards a hydrolysis reaction. While in an absorption column this is a desirable system property, as it leads to higher reactivity towards $\mathrm{CO}_{2}$ (as reported 
in Chapter 4), in the regenerator this high concentration of stable carbamate species leads to an increased energy demands for solvent regeneration, and needs to be carried out at slightly higher temperatures when compared to, e.g., the MEA process (Chapter 5). These system limitations have been reported also for other amino acids, e.g., sarcosine and glycine (Erga et al., 1995; Knuutila et al., 2011; Song et al., 2008). A reduction of the stability of carbamates formed during $\mathrm{CO}_{2}$ absorption will be an important factor for creating a more energy efficient process based on amino acid salts.

Recently, the $\mathrm{pH}$ swing method based on an addition of a $\mathrm{pH}$ control agent (e.g. a weak organic acid) to $\mathrm{CO}_{2}$-loaded solvent has been proposed as a way to lower the energy required for solvent regeneration (Feng et al., 2010; Lee et al., 2012). Basically, the method involves an introduction of an acid to a rich solution prior to the regeneration section and its removal from a lean solution, before that one enters the absorber column, through crystallization by a temperature drop. When the acid is introduced to the solution, dissociation reaction takes place producing $\mathrm{H}^{+}$ions. Higher concentration of $\mathrm{H}^{+}$ions in the solution creates an additional driving force (next to the thermal treatment) for shifting equilibria of reactions producing carbamate and bicarbonate ions towards a release of $\mathrm{CO}_{2}$ molecules. As a result, the reboiler duty required for solvent regeneration can be reduced significantly compared to the conventional process; as demonstrated for the MEA solvent (Feng et al., 2010). An alternative method to "acidify" the rich solution would be to use electricity to split water into $\mathrm{H}^{+}$and $\mathrm{OH}^{-}$ions using bipolar membrane electrodialysis. In the $\mathrm{pH}$ swing process, a decrease in the reboiler duty is mainly due to a reduction in the heat of evaporation. This heat represents a major contribution to the reboiler duty of amino acid salts (as shown for L-prolinate in Chapter 5 ).

Also the phenomenon of precipitation upon $\mathrm{CO}_{2}$ absorption in amino acid salts solutions could be utilized to make the acid gas capture process more energy efficient. This option is targeted by TNO (the Netherlands) in their DECAB and DECAB Plus processes under development; and screening the operating regime and types of precipitates was reported in this work in Chapter 2. As a result of the solid phase formation, a rich stream with an increased $\mathrm{CO}_{2}$ loading can be obtained. In the DECAB process, the equilibrium of the system is shifted back to a gaseous acid and a (semi) lean absorption liquid by the thermal regeneration. Initial pilot plant tests indicated that this system can be more compact and more energy efficient (requiring less thermal energy for solvent regeneration due to increased rich loading) when compared to commercial (alkanol)amines (Feron and ten Asbroek, 2004). This $\mathrm{CO}_{2}$ enrichment by precipitation was found also for L-prolinate solutions in this work. The newly developed DECAB Plus process goes a step further and utilizes a $\mathrm{pH}$ shift induced in the system by precipitation of the amino acid under consideration (Sanchez Fernandez, 2013). In that process, part of a clear liquid supernatant phase, separated from the solids rich slurry, is recycled without further regeneration to the 
absorber. The remaining solid amino acid rich slurry is sent to the regenerator. This stream will, upon heating and dissolution of the precipitate, form a new rich solution with a reduced $\mathrm{pH}$ than the original one formed during absorption. This $\mathrm{pH}$ reduction creates an additional driving force for $\mathrm{CO}_{2}$ release in the stripper. The optimum fraction of supernatant to recycle directly was found to be around $30 \%$, resulting in the amino acid to $\mathrm{K}^{+}$molar ratio of around 1.2. This enhanced desorption leads to lower water to $\mathrm{CO}_{2}$ molar ratios in the regenerator overhead stream and (as main effect) to lower enthalpy of desorption. Both effects combined lower the reboiler energy for solvent regeneration in the DECAB Plus process, under optimised conditions and excluded low-grade energy for dissolving the precipitated solids, by $35 \%$ compared to the MEA solvent (Sanchez Fernandez, 2013).

In principle, this $\mathrm{pH}$ shift concept could be applied to any three phase aqueous amino acid salt- $\mathrm{CO}_{2}$ system. In the case of potassium (or sodium) salts of L-prolinate and sarcosinate, amino acid salt solutions studied in this thesis, the precipitate formed is not the corresponding amino acid species itself but potassium (respectively sodium) salt of bicarbonate. Here, the potassium bicarbonate solid formed could be separated from the rich slurry coming from the absorber, to increase the amino acid to $\mathrm{K}^{+}$molar ratio in the stream to be sent to the regenerator. To create a similar amino acid to $\mathrm{K}^{+}$molar ratio of 1.2, equal to the optimum case in the potassium taurate-based DECAB plus process, around $16 \%$ of the potassium ions should be precipitated and separated from the stream. From the results in Chapter 3 of this thesis, it can be calculated that this just coincides with the amount of precipitate formed for $3 \mathrm{~mol} \cdot \mathrm{dm}^{-3}$ solution of potassium L-prolinate at the equilibrium conditions at $285 \mathrm{~K}$ (see Figure 3.4). Whether or not a similar strong reduction of the reboiler duty is indeed obtained would require further (experimental) validation, which is beyond the scope of this thesis.

Whereas in the original DECAB Plus process the separated fraction is recycled directly (without regeneration) to the absorber, a potential benefit of these bicarbonate precipitating solvents is that the separated fraction is a solid product which can be sold, stored or regenerated separately, next to the option of direct recycling. The choice of the counterion (potassium vs. sodium) might influence the optimum process conditions as potassium bicarbonate is significantly more soluble in water than sodium bicarbonate (Söhnel and Novotny, 1985); making the latter one more suitable for application using precipitation. Below, potassium (bi)carbonate is used as an example but one might read also the sodium variants in its place.

In case of removing bicarbonate as a product from the system, an equimolar amount of potassium in the form of $\mathrm{KOH}$ must be added to the system. Partial regeneration of the solid bicarbonate to potassium carbonate $\left(\mathrm{K}_{2} \mathrm{CO}_{3}\right)$ under release of $\mathrm{CO}_{2}$ and water can be 
done thermally by heating above $323 \mathrm{~K}$. Potassium carbonate formed could be contacted with calcium hydroxide (slake lime solution) to yield the precipitated calcium carbonate as a product and an alkaline potassium hydroxide solution to be recycled to the absorber. Alternatively, the $\mathrm{CO}_{2}$ captured in the form of a solid bicarbonate salt could also be used, for example, as a feedstock for algae culture. Possibly a $\mathrm{CO}_{2}$ permeable membrane system can be used to keep the bicarbonate (re-dissolved in water) feed stream separate from the algae cultivation broth. In such a configuration, the regenerated, alkaline solution could be resend to the absorber.

In all cases, including the DECAB Plus system, a drawback of working with precipitating systems is that they require relatively high solvent loading leading to lower free amino acid concentration and hence relatively slow kinetics (Simons et al, 2010). A separate, dedicated techno-economic evaluation is therefore needed to assess whether the anticipated reduction in the regeneration energy is sufficient to offset possible additional capital costs for the absorber section. 


\section{Bibliography}

Erga, O., Juliussen, O., Lidal, H., 1995. Carbon dioxide recovery by means of aqueous amines. Energy Conversion and Management 36, 387-392

Feng, B., Du, M., Dennis, T.J., Anthony, K., Perumal, M.J., 2010. Reduction of energy requirements of $\mathrm{CO}_{2}$ desorption by adding acid into $\mathrm{CO}_{2}$-loaded solvent. Energy and Fuels 24, 213-219

Feron, P.H.M., ten Asbroek, N.A.M., 2004. New solvents based on amino-acid salts for $\mathrm{CO}_{2}$ capture from flue gases. GHGT-7, Vancouver, Canada

Hamborg, E.S., Niederer, J.P., Versteeg, G.F., 2007. Dissociation constants and thermodynamic properties of amino acids used in $\mathrm{CO}_{2}$ absorption from 293 to $353 \mathrm{~K}$. Journal of Chemical and Engineering Data 52, 2491-2502

Hamborg, E.S., van Swaaij, W.P.M., Versteeg, G.F., 2008. Diffusivities in aqueous solutions of the potassium salt of amino acids. Journal of Chemical and Engineering Data 53, 1141-1145

Van Holst, J., Versteeg, G.F., Brilman, D.W.F., Hogendoorn, J.A., 2009. Kinetic study of $\mathrm{CO}_{2}$ with various amino acid salts in aqueous solution. Chemical Engineering Science 64, 59-68

Knuutila, H., Aronu, U.A., Kvamsdal, H.M., Chikukwa, A., 2011. Post combustion $\mathrm{CO}_{2}$ capture with an amino acid salt. Energy Procedia 4, 1550-1557

Lee, H.S., Seo, M.D., Kang, J.W., 2012. Measurement and correlation of of the solubility of carbon dioxide in the mixtures of aqueous monoethanolamine solution and benzoic acid. Journal of Chemical and Engineering Data 57, 3744-3750

Sanchez Fernandez, E., 2013. Novel process designs to improve the efficiency of postcombustion carbon dioxide capture. Ph.D. Thesis, TU Delft, The Netherlands

Simons, K., Brilman, D.W.F., Mengers, H., Nijmeijer, K., Wessling, M., 2010. Kinetics of $\mathrm{CO}_{2}$ absorption in aqueous sarcsine salt solutions: influence of concentration, temperature, and $\mathrm{CO}_{2}$ loading. Industrial and Engineering Chemistry Research 49, 9693-9702

Song, H.J., Lee, S., Park, K., Lee, J., Spah, D.C., Park, J.W., Filburn, T.P., 20o8. Simplified estimation of regenration energy of 30 wt \% sodium glycinate solution for carbon dioxide absorption. Industrial and Engineering Chemistry Research 47, 9925-9930

Söhnel, O., Novotny, P., 1985. Densities of aqueous solutions of inorganic substances. Elsevier, Amsterdam 



\section{Acknowledgements}

This research has been sponsored by the CATO program and was carried out initially in the OOIP research group and later continued in the SPT research group at the University of Twente. THANK YOU to all the people who have contributed to this research.

I would like to express my gratitude to all supervisors with whom I worked at different stages of my Ph.D. research.

I am very thankful to Prof. dr. ir. Geert F. Versteeg for giving me the opportunity to carry out this Ph.D. study and his valuable input and support provided in the early stage of this research. My appreciation is extended to Dr. ir. John P. M. Niederer.

I would like to express my sincere gratitude and appreciation to my promoters Prof. dr. Sascha R. A. Kersten and Prof. dr. ir. Wim P. M. van Swaaij for their expert guidance and support provided in the last phase of this research. I am especially grateful to Sascha for words of encouragement and in-depth critical discussions we had. I am honoured to have the opportunity to work with Prof. van Swaaij, a true legend in the chemical engineering world. My sincere gratitude goes also to the late Prof. dr. ir. Michiel J. Groeneveld for his valuable guidance provided in the middle stage of this study.

One person with whom I had the pleasure to work for the longest period of time is Dr. ir. D.W.F. Brilman (Wim). Dear Wim, you are a very special person and an outstanding scientist. I will really miss our cooperation. Thank you for everything.

Several others have also contributed to this work. The scientific inputs of Maria, Tassos and Vic were much valued and appreciated. The contributions of Dr. ir. A.G.J. (Louis) van der Ham and Ir. B. Fränzel-Luiten (Erna) were highly appreciated.

Yvonne Bruggert-ter Huurne is acknowledged for the organizational input. The efforts of Ir. Erik Lysen regarding the continuation of this Ph.D. study were highly appreciated.

My gratitude goes to Espen, Katja, Prachi, Željko and my SPT colleagues for the enjoyable time during working hours. I will always remember the great times and many laughs I 
shared with Cristiano, Davide, Karina and Kumar either while working in the laboratories or outside the university.

I would like to sincerely thank my paranimfen Agata and Izabela for their friendship and for standing by my side in this important day.

I would especially like to thank my son Mikołaj, who favours green toys over all others, for inspiring the cover of this dissertation and a colour of the figures.

Anetko i Arturze dziękuje za Waszq troskę i wsparcie.

Finally, my deepest gratitude and appreciation go to my family.

Pragnę serdecznie podziękować rodzicom Elżbiecie i Stanisławowi, bratu Pawłowi, bratankowi Kasprowi, śp. babci Janine, cioci Hani i jej rodzinie, teściom Renie i Piotrowi za miłość oraz wsparcie.

Arturze i Mikołajku, ten wiersz jest o Was.

$\begin{array}{ll}\text { Jesteś powietrzem } & \text { czym ty jesteś - } \\ \text { które drzewa pieści } & \text { dla mnie - świeżq̨ woda } \\ \text { rękoma z błękitu } & \text { wytrysła na skwarnej pustyni } \\ \text { jesteś skrzydtem ptaka } & \text { sosnq - która cień daje } \\ \text { który nie trąca liści } & \text { drżącq osikq - która współczuje } \\ \text { płynie } & \text { dla zziębniętych - stońcem } \\ \text { jesteś zachodnim słońcem } & \text { dla konających - bogiem } \\ \text { pełnym świtów } & \text { ty - rozbłysty w każdej gwieździe } \\ \text { bajkq ze stów które mówi się } & \text { której na imię miłość } \\ \text { westchnieniem } & \\ \text { „esteś powietrzem” } & \\ \text { Halina Poświatowska (1935-1965) } & \end{array}$

\section{Magdalena}



